\title{
6 Towns, leagues and landholding elites: the early-Hellenistic period, c. 370/350-250/230 BC
}

\section{I I T T O D U C T I O N : A N CIEN T W R T T T N S O URCESA A H I S T O R Y}

In chapter 5 we have seen that many factors contributed to the rise of the spectacular societies of the 6 th and 5th centuries BC. Among these were the more sedentary character, the demographic growth and the increasing complexity of the societies of 7th-century Italy together with the arrival of migrants from Aegean areas. The latter brought new technical skills, had other forms of social and economic organization and had different ideas, norms and values. In the 6th century four states (poleis) came into being in southeast Italy proclaiming an overtly Greek identity, while three or four powerful indigenous tribes arose from the fairly segmented clan world of the 7th and early 6th centuries BC. These profound changes in the native world of southeast Italy happened between the late 6th century and the middle of the 5 th century BC.

New developments, however, did not manifest themselves with the same speed and the same intensity in every part of the region discussed in this book. They occurred in large parts of Basilicata and in central and southern Apulia. In the so-called 'Daunian' districts of northern Apulia, however, situations and features as sketched for the Iron Age and Archaic-Classical period in the preceding chapters continued to live on till well into the 3rd century BC. ${ }^{1}$ In settlement form, craft, religion and socio-economic organization the north-Apulian groups of the 6th to 3rd centuries BC displayed greater similarities to the Sabellic groups in the more northerly Abruzzo-Molise areas than to their more southern fellow-Apulians.

The rise of the four poleis of southeast Italy has been discussed in the preceding chapter. During the later 6 th and early 5 th centuries, when these new socio-political realities asserted themselves, southeast Italy was in great turmoil. Greeks fought Greeks, battles raged between non-Greek groups, and violent clashes between south-Italic Greeks and non-Greek tribes also occurred. Taras and Metapontion continued to be poleis during the 6th, 5th and 4th centuries BC. Siris and Sybaris, however, are reported by ancient authors to have been destroyed by neighbouring Greek poleis. ${ }^{2}$ They both lost their independent status of city state in the 2 nd half of the 6th century. The excavations have demonstrated that these settlements were not completely abandoned as was formerly believed. They continued to be inhabited during the first half of the 5th century, although the traces of human presence seem less intense than in the preceding and subsequent phases. Both settlements were raised again to the status of polis in the later 5th century BC. What remained of Sybaris received an influx of new settlers and was transformed into the pan-Hellenic apoikía of Thourioi (founded in 444 BC). In the same way the settlement which had once been the polis of Siris, became the new polis of Herakleia in Lucania in c. 435 BC. ${ }^{3}$

1 Here, for instance, highly dispersed settlements and matt-painted pottery continued to exist to well within the 3rd century BC.

2 'Ionian' Siris was reportedly destroyed by a coalition of three 'Achaean' poleis (Kroton, Sybaris, Metapontion), while Sybaris was destroyed by its Greek neighbour Kroton.

Lomas 1993, 31. 
Drastic changes are equally reported for the non-Greek districts of southeast Italy. These, however, are not really apparent in the ancient written sources concerning the region of Apulia. The ancient authors continued to use the same names for the native groups they could identify in this $350 \mathrm{~km}$ long, Messapic speaking area along the Adriatic coast: the Messapians in the south, the Peucetians in the centre and the Daunians in the northern part of Apulia. The Messapians, living close to the polis of Taras, were restive and required the closest attention of both the Tarantine leaders ${ }^{4}$ and the condottieri from Greece who were invited by the Tarantines. ${ }^{5}$ The general image of the Tarantine-Messapian conflicts of the 4 th century $\mathrm{BC}$ is one of mutual harassing and recurring border raids. No large, impressive battles or other conspicuous historical events have been reported by ancient authors for this particular area. ${ }^{6}$

What happened in Basilicata, however, was vastly different. Here, the non-Greek tribal groups known as Opikoi, Oinotrioi and Chaones of archaic times disappeared from the record and all of a sudden highly threatening Lucanians made their appearance on the south-Italian stage. Passages of ancient authors on this matter suggest that the Greeks were quite unexpectedly confronted with an entirely new and very powerful native tribe. There is, however, no coherent ancient account on the Lucanian threat and the Lucanian conquest of formerly Greek parts of southern Italy. The surviving passages that are relevant to the present subject are invariably short and stem from Greek authors living in southern Italy or Sicily who were quoted by much later writers such as Athenaeus, Pliny, Polyaenus, Strabo and Diodorus. These written sources, therefore, are both patchy and biased. We must deal with dispersed fragments of texts that have lost their contexts. Therefore they cannot be the object of discourse analysis in order to establish their biases and rhetorics. Since the indigenous groups of southeast Italy had no written history, we are exclusively informed on the Greek and Roman views on all things native.

This notwithstanding, the problem of the sudden rise of the Lucanians has spawned a huge bibliography. The main questions that have been addressed were: Who were these Lucanians? Where did they come from? And how did they manage to become so threatening and powerful in a relatively short time? The answers that have been formulated, regard predominantly the first two questions. We are told by both the Graeco-Roman geographer Strabo and the Roman encyclopaedist Pliny the Elder that the Lucanians were of Sabellic stock: ${ }^{7}$ they were basically Samnites. It is quite obvious that both authors derive their information from the same source. ${ }^{8}$ On the strength of these passages of Strabo and Pliny, the Lucanians are usually portrayed as a group of central-Italic peoples that moved into Basilicata and completely unsettled and replaced the indigenous groups living there. Their arrival, therefore, disrupted nearly all pre-existing cultural features, from settlement patterns to pottery styles. ${ }^{9}$

The Lucanians have been and still are commonly perceived as aggressive invaders who rapidly spread over much of Basilicata and adjacent regions. They wiped out the pre-existing native groups of these areas and posed a severe threat to the Greek towns on the coast. We have noted that this image of the Lucanians created on the basis of fairly sparse ancient written sources, dominates the views on the past of the Basilicata region. There is, therefore, good reason to look into this matter critically. We must establish whether this image of mass migration and thorough ethnic cleansing is plausible and whether it is also supported by evidence supplied by archaeological sources.

One of the highly threatening aspects of the Lucanian expansion that emerges from the ancient written sources, is the sheer scope of the phenomenon. All at once, the Lucanians seem to be every-

E.g. Archytas in the 370s and 360s.

5 King Archidamos of Sparta and Alexander the Molossian in the 330s.

6 For the Tarantine leader Archytas and the so-called condottieri, see, for instance, Wuilleumier 1939 and Lomas
1993, 39-57.

Strabo, VI.1.3; Pliny, III.71.

Laserre 1967, 15.

cf. Greco Pontrandolfo 1982, 100; Bottini 1990b; Lomas 1993, 33. 
where. First they marched on Thourioi on the Gulf of Taranto in about 433, next they took Posidonia in southern Campania in 410, whilst they conquered Terina in the toe of the Italian boot in 395 BC and Laos in northern Calabria in $390 .{ }^{10}$ Vigorous military actions by the obviously charismatic Tarantine strategos and Pythagorean philosopher Archytas seems to have marked a period of relative quiet in southeast Italy during the 370's and 360's. Soon afterwards the practice came into being of inviting condottieri from Aegean Greece in order to keep these barbarians aloof. ${ }^{11}$ This indicates that the pressure exerted by the Lucanians on the Greek poleis of southern Italy, was very considerable indeed and that the nightmare of recurring Lucanian raids and marauding Lucanian war bands roaming the countryside continued to haunt these Greek states for many years.

The image of both the Sabellic origin and the sudden rise of the Lucanians was supported, it seemed, by archaeological evidence. The archaeological data for the 5th century BC in Basilicata, and especially the period between c. $470 / 450$ and $400 \mathrm{BC}$, were believed to be extremely scanty. ${ }^{12}$ There seemed to be a hiatus in the occupation of many sites suggesting discontinuity in the settlement history of the region. ${ }^{13}$ The second argument was a hiatus and a major shift in material culture: the ceramics of the late 5th century $\mathrm{BC}$ differed radically from the pottery produced at the beginning of the 5th century BC. Op top of this, the way the deceased were deposited in their inhumation graves, was reported to have changed substantially. Whilst the bodies were put on their sides in contracted position before the 5th century BC, they were laid outstretched and on their back from the later 5th century onward..$^{14}$ The appearance of a series of chieftain's burials containing bronze, so-called 'Samnite' belts from the late 5 th century onward was a fourth element that was thought to stress the profound changes that affected large parts of Basilicata. ${ }^{15}$ The 'Samnite' belts were believed to be indicative of the ethnic affiliation of the person buried in the grave. ${ }^{16}$ These four features were seen as clear signs of the migration of substantial Samnite groups into Basilicata. Their arrival, it was almost generally believed, caused discontinuity in the settlement patterns and substantial shifts in the material culture of the region and was, moreover, held responsible for the introduction of new burial rites and a new type of prestige goods (the Samnite belts).

This view won wide acceptance, because the interpretation of both the ancient written sources and the archaeological data seemed to support each other and almost inevitably led to this conclusion. ${ }^{17}$ The question, however, is whether the interpretations of both sources that seem to tie in so nicely, are actually correct and whether both the quality and the quantity of the data really warrant the conclusion that the Lucanians were indeed predominantly Sabellic invaders.

The image of the rise of the Lucanians as sketched during the 1980s and 1990s has some flaws. It is, for instance, decidedly odd that invading bands of mountain dwelling newcomers (the Lucanians) succeeded in unsettling and replacing apparently strong and well-organized tribes like the Opikoi, Chaones and Oinotrioi of 6th- and early 5th-century Basilicata. It is equally odd that these same montani atque agrestes, as Livy would have put it, managed to threaten and conquer highly organized Greek polities on the coast within decades of their arrival. ${ }^{18}$ Mass migration, moreover, has been a spiny topic in archaeology over the past twenty years. It is, therefore, fairly surprising that the cliché view that the new and powerful tribe of the Lucanians of the later 5th and 4th centuries BC were basically Samnite-Sabellic invaders has hardly been challenged in recent years.

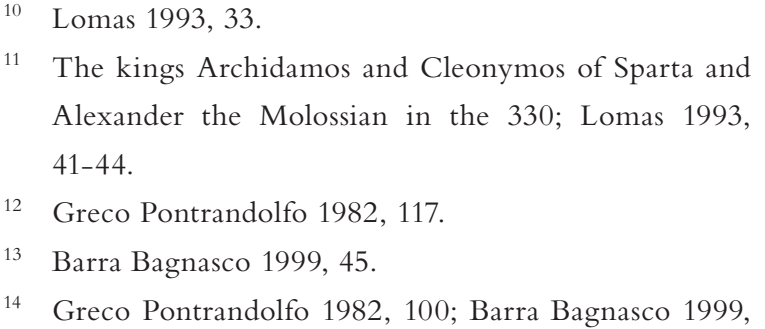

45.

15 Bottini 1985.

16 For these Samnite belts, see Suano 1986, Bottini 1993.

17 Frederiksen 1984, 136-137; Lomas 1993, 33-34.

18 The Latin quote can, of course, be found in Livy (IX.13) who wrote these words to characterize the not-too-sedentary Volsci. 
A first careful and multi-facetted explanation has been proposed by Lombardo who stated that migrants of Sabellic origin were only one of the elements that contributed to the 'Lucanization' of Basilicata. ${ }^{19}$ Torelli nuanced the mass migration model by proposing that only the indigenous elites were replaced by Samnite invaders. ${ }^{20}$ In a short note I have attempted to demonstrate that the occupational discontinuity of the 5th century BC is probably more apparent than real: the current chronologies are based on pottery seriations built on probably false assumptions. ${ }^{21}$ Solid 5th-century phases, moreover, have been recognized at sites in the Lucanian heartland (fig. 6.1). ${ }^{22}$ This delivers us from the occupational discontinuity that was believed to have been the result of the coming of the Lucanians. ${ }^{23}$ The change in material culture in the indigenous areas of Basilicata was probably caused by the adoption of cultural features from the neighbouring Greek-Italic poleis in the course of the 5th century BC. Material culture in large parts of Basilicata did not 'Samnitize', but 'Hellenized'. It began to display more and more features that were characteristic of the Greek poleis of southeast Italy. ${ }^{24}$

In this way two seemingly strong 'archaeological' arguments for a Samnite origin of the Lucanians have been refuted. The third regarded a change in burial customs: inhumations were believed to change from contracted (on the side) to outstretched (on the back). A closer study of the burial customs in Basilicata and surrounding areas, however, reveals that the 'new' way of burying the deceased (outstretched, on the back), occurred in indigenous contexts of western Basilicata and adjoining parts of the present-day regions of Campania and Calabria as early as the 8th and 7th centuries BC. ${ }^{25}$ The same burial form was, moreover, very common in the Greek poleis on the coast from the later 7th century onward. ${ }^{26}$ The spread of this slightly different burial custom over central and southern Basilicata, therefore, is unlikely to represent the diffusion of an evidently Sabellic cultural feature. The same holds good for the distribution of 'Samnite' belts over Basilicata and northern Apulia. ${ }^{27}$ The archaeological evidence for a penetration of substantial Samnite-Sabellic groups into Basilicata in the 5th century $\mathrm{BC}$, therefore, is very thin indeed

In the present state of research, the vast majority of the group indicated as Lucanians by their Greek neighbours is likely to have consisted predominantly of people whose forebears had lived in Basilicata for many generations. Though small groups of migrants from central Italy may well have joined them, most of the people who were thought to be (or even saw themselves as) Lucanians were certainly not new to the region. That the Greek author Strabo gave them Samnite origins, can be explained in various ways. ${ }^{28}$ The new term of Lucanians, therefore, did not come into being because the people indicated in this way represented an entirely new group of invaders, but because the Lucanians were perceived, and probably perceived themselves, as an entity that differed markedly from pre-existing groups. But basically the term was a new label and perhaps stood for a new group identity assumed by people whose fathers or grandfathers had been named by others (or considered themselves as) Opikoi, Oinotrioi or Chaones.

19 Lombardo 1987, 55.

20 Torelli 1996, 128-129.

21 Yntema 1997.

22 Holloway 1970; Lissi Caronna 1980, 1983 and 1990/91; Greco 1991; Osanna / Sica 2005; Osanna 2007.

23 It was, of course, odd that several settlements of Basilicata were abandoned in the course of the 5th century and were reoccupied towards the end of the 5 th or in the early years of the 4th century BC.

24 Kok 2004.

25 La Genière 1968; Bianco / Tagliente 1985.

26 De Juliis 2001.

27 The presence of a Samnite belt in a south-Italian grave, of course, does not make the deceased a Samnite. Such prestige items proclaimed rank and were not indicative of ethnic identity. They could well have played a role in the inter-regional exchange between elites.

28 The Lucanians may, for instance, have had origo myths linking them to the Samnites. This may have been reshaped or invented history. Another possibility is that in Roman historiography the threatening mountain dwellers are often Samnites. Strabo (or his source) may have made a connection between mountain tribes that harassed Roman lands (the Samnites) and similar groups that threatened Greek polities (the Lucanians) 

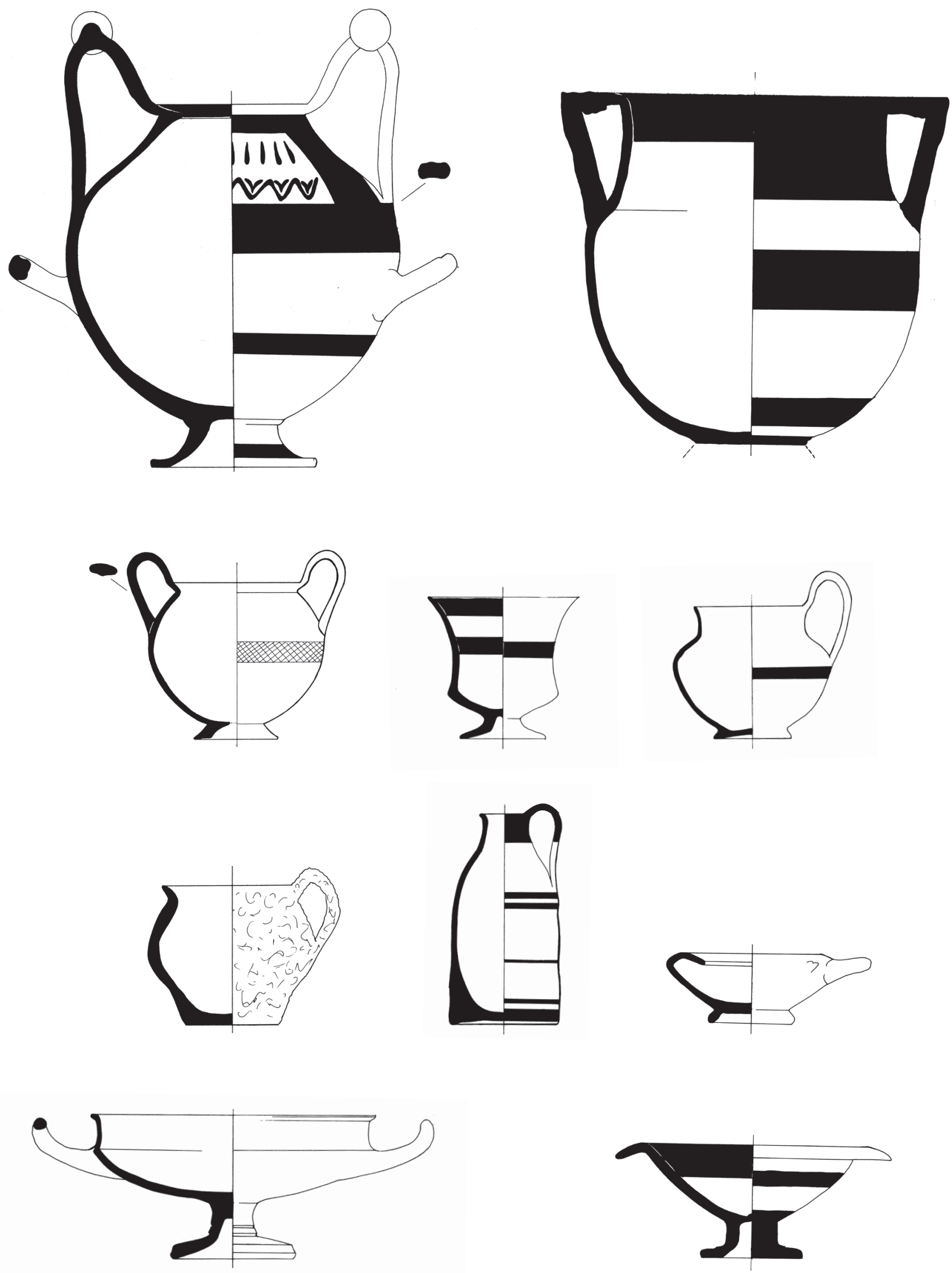

Fig. 6.1. Torre di Satriano. Tomb of the mid 5th century BC with traditional forms and new Grecian forms. Scale 1:4. After Holloway 1970. 
In my view, therefore, the Lucanians are a somewhat loose confederation of fairly coherent cantonal groups. This new socio-political entity grew out of earlier resident groups that had lived in the same areas in preceding centuries. Well before the middle of the 5th century BC the various groups living in Basilicata cooperated more frequently and more intensely than in earlier times. Possibly there was an admixture of some Sabellic groups who lived in adjoining areas, spoke the same language and were not really different from their southern neighbours. But the great novelty was that the constituent groups of the new confederation developed a sense of shared identity. They were no longer exclusively the group or tribe (Oscan: touto) living in that particular valley with that particular central place; they believed that they also belonged to a larger entity. The new identity that was shared by various tribal groups of Basilicata was inter alia expressed in the new, typically Italic name, in an origo myth that suggested their Samnite pedigree ('Lucanians' = 'the wolf people'), in a probably pan-Lucanian sanctuary (Rossano di Vaglio) where the whole Nomen Lucanum is likely to have gathered on particular occasions and (perhaps occasionally) in the election of a paramount chief who was the living symbol of Lucanian identity. ${ }^{29}$ Serra di Vaglio (only $6 \mathrm{~km}$ from Rossano di Vaglio) with its impressive architecture is sometimes believed to have been the central place of the whole Nomen Lucanum.

The ancient written sources suggest that the Greek poleis of southern Italy perceived this much larger tribal entity as a severe threat. ${ }^{30}$ We have seen that some Greek towns of southern Italy were even said to have been taken over by the Lucanians. This reportedly happened to Posidonia (Paestum). The material culture of Posidonia (Lucanian: Paistom) of the 4th century BC differs vastly from that of the 6th and earlier 5th centuries BC and displays considerable affinities with that of contemporary inland areas of Basilicata with 'native' populations. ${ }^{31}$ Whether this take-over happened by force or was simply a case of integration between south-Italic Greeks and south-Italic natives is unclear. ${ }^{32}$ The complete barbarization and even enslavement of the Greek inhabitants as aired in some Greek sources can probably be taken as anti-Lucanian rhetoric in a situation of strongly conflicting interests. ${ }^{33}$

The increased level of organization of the non-Greek populations of southeast Italy and the new dangers that resulted from it, required an answer from the Greek states of the region. With their probably more strict and intricate forms of organization in the fields of politics and military affairs the Greek states of Thourioi (formerly Sybaris), Herakleia (formerly Siris), Metapontion and Taras had a distinct advantage over the Lucanian groups. But this was compensated by the much larger population figures of the native tribal groups. Moreover, the Lucanians may well have chosen to adopt particular features of Greek military tactics and organization and elaborated and refined similar features from their own cultural background that were advantageous in their eyes. In this way they became formidable adversaries to the Italiote Greeks and were a danger that did not differ much from the threat posed by the united tribes of Macedon under king Philip II for the polis states of central and southern Greece.

The Greek answer to the genesis of the supertribe of the Lucanians was the strengthening of the Italiote League. This league is likely to have come into being in the late 6th or early 5th century BC when it was initially headed by Kroton. ${ }^{34}$ By the first half of the 4th century BC, however, Taras was the unchallenged hegemon among the Greek towns of southeast Italy. The role of this polis was, in fact, so dominant that Tarantine policy cannot be distinguished from Italiote League policy. Other Greek

29 Cf. the appearance of 'royal' burials between late late 6 th and the middle of the 5th century BC: see preceding chapter: burials of Baragiano (late 6th/early 5th century), Serra di Vaglio-Braida (first half 5th century), and Melfi-Pisciolo (mid 5th century).

30 The ancient sources concerning the Lucanians have been collected in Cordano 1971.
31 Pedley 1990; Pontrandolfo / Rouveret 1992.

32 Lomas 1993, 34

33 The most celebrated passage on this matter was written by Aristoxenos of Taras (cited by Athenaeus, Deipnosophistai XIV.31.632) who said that the Lucanians of Paestum did not allow the Greeks to speak Greek except at one yearly festival (cf. Pedley 1990, 97). 


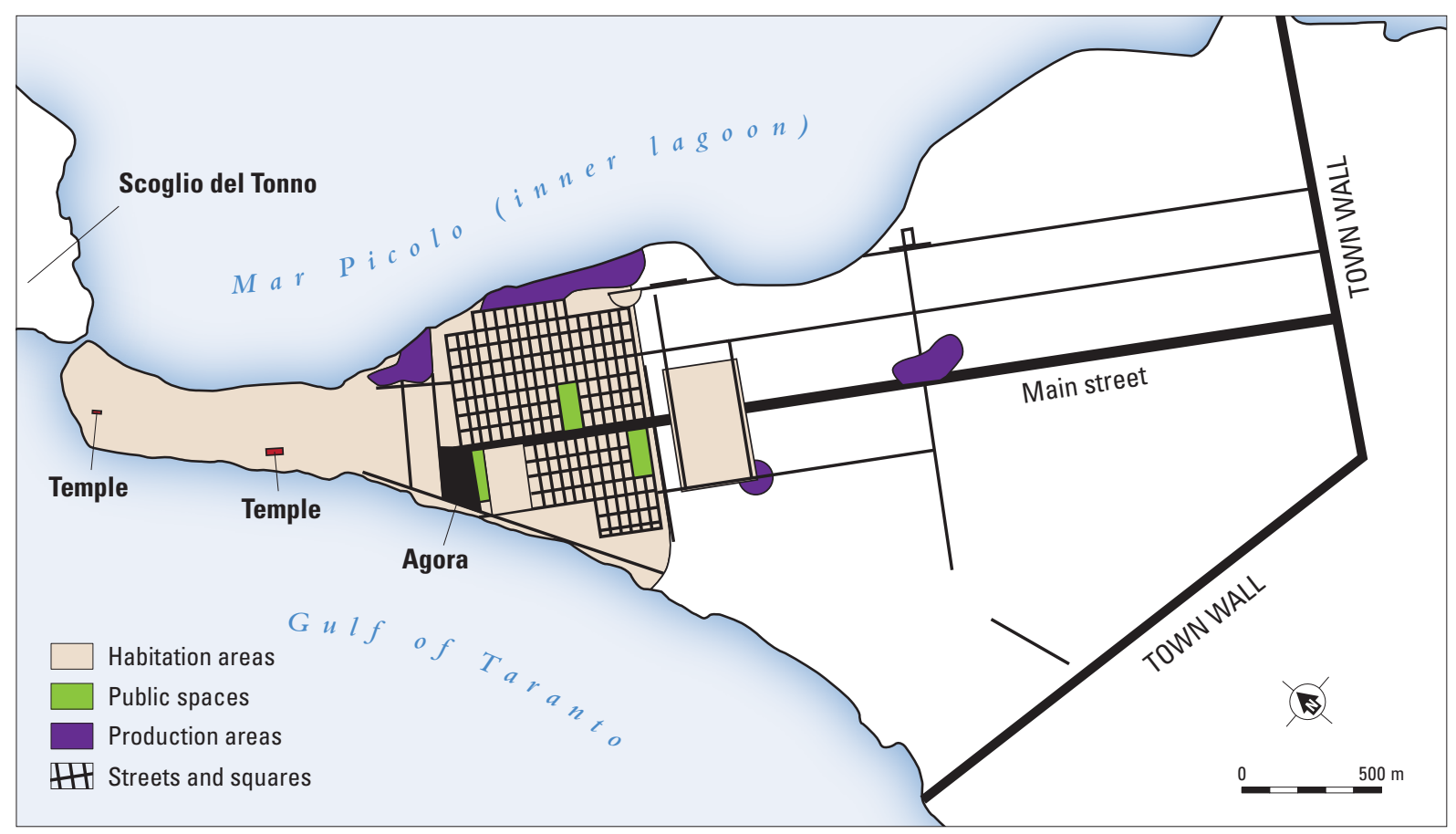

Fig. 6.2. Town plan of Taras with fortifications and orthogonal layout (4th century BC). New drawing based on Lippolis 1997.

towns of southeast Italy cooperated with Taras - albeit grudgingly in some cases - in various enterprises staged to keep the Lucanians at bay. It was Taras that invited the condottieri during the later 4th and the early 3 rd centuries.

It was again Taras that took the lead in the Pyrrhic war against Rome (280-272) which ended in the Roman supremacy over southeast Italy. The first intensive contacts between Rome and the south-Italians dated to the last quarter of the 4th century BC when Rome was at war with the Samnites. After her ignominious defeat at the Caudine Forks (321 BC) Rome sought to rally support behind the back of the Samnites. It did so by befriending 'Daunian' settlements in northern Apulia such as Canusium (now Canosa) which became one of Rome's most faithful allies in southeast Italy. ${ }^{35}$ Rome founded Latin colonies at north-Apulian Luceria (314 BC) and at Venusia (291 BC). ${ }^{36}$ Since the Canosa area was closely connected with Metapontion and Taras, the Roman presence in northern Apulia could well have been perceived as a Roman infringement upon the Tarentine sphere of influence.

The Pyrrhic war was basically a clash between the most powerful state of southern Italy (Taras) and the most powerful state of central Italy (Rome). In this dangerous conflict Taras had recourse to the well-known solution of attracting condottieri and called in king Pyrrhus of Epirus. Taras and Pyrrhus managed to make a powerful coalition consisting basically of Italiote poleis and Lucanian, Messapian and even Samnite groups. The disastrous character of Pyrrhus' victories at Herakleia in Lucania and

34 Lomas 1993, 32.

35 During the Second Punic war, even after the disastrous battle of Cannae at only a few miles from Canosa, the Canosans continued to be faithful to Rome and helped the Roman soldiers who had survived the battle. The equally important 'Daunian' settlement of Arpi went over to Hannibal. (see chapter 7.1).

36 Luceria (now Lucera) was probably originally a 'Daunian' settlement; Venusia (now Venosa) was probably situated in a territory taken from Samnites or Lucanians. 


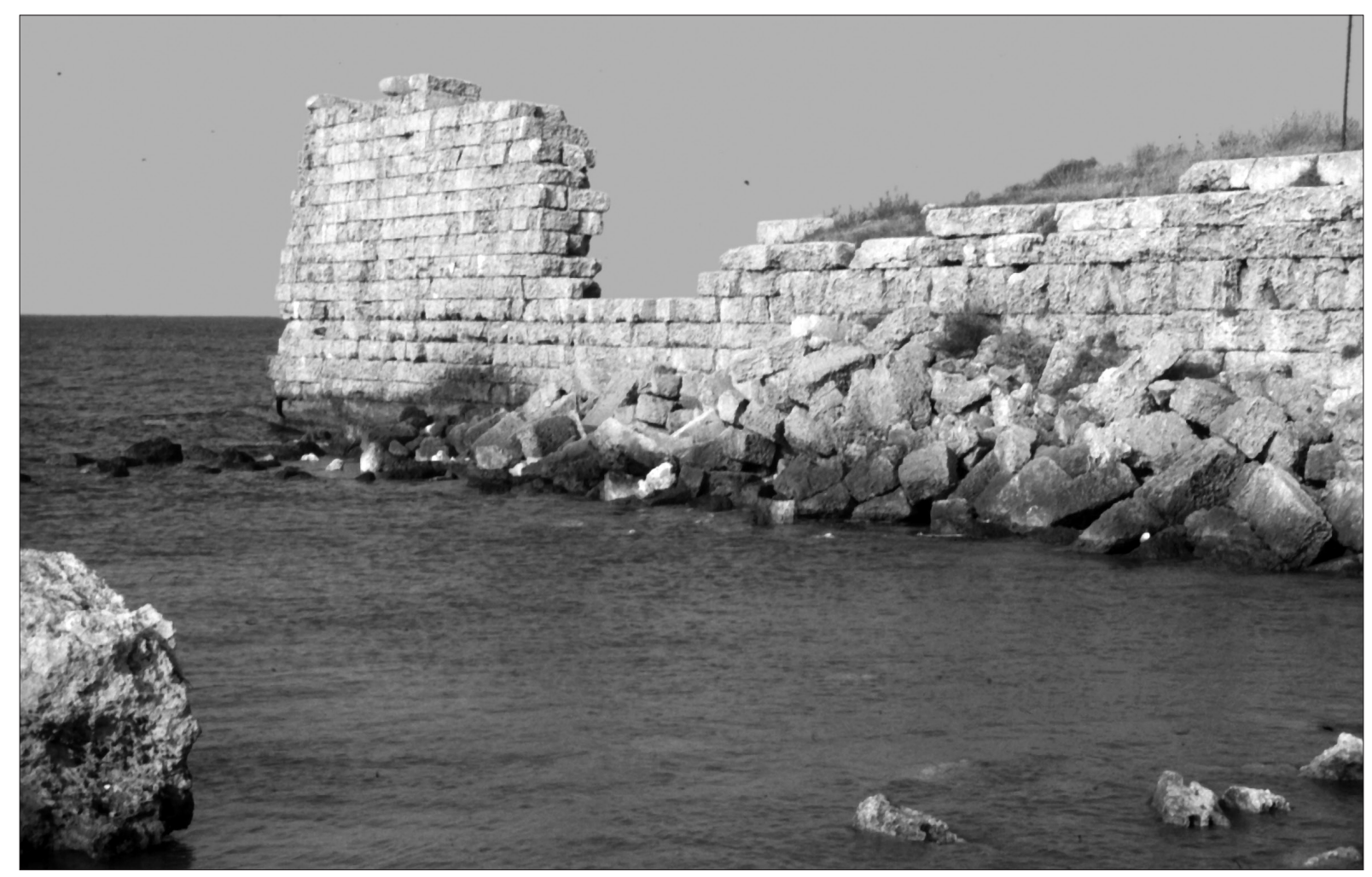

Fig. 6.3. Fortifications of Gnathia (northern Salento), preserved height c. 6 m (archive ACVU).

Ausculum in Daunia, ${ }^{37}$ the tenacity of the Romans and Pyrrhus's two years' stay in Sicily (278-276 BC) were not particularly helpful in keeping the coalition together. After loosing the crucial battle of Beneventum (275 BC) Pyrrhus left Italy. Wealthy Taras was taken by the Romans in 272. The last area of peninsular Italy to be conquered was the Salento peninsula. The Fasti Triumphales mention triumphs de Sallentineis Messapeisque ('over the Sallentini and the Messapii') for the years 267 and 266 BC.

Summarizing the information from ancient written sources it seems evident that they suggest the genesis of larger and more powerful tribal entities in southeast Italy. These were seen as a serious threat to the Greek states of the region. The increased pressure of the tribes on the Greek poleis resulted in a strong Greek-native opposition for much of the 4th century BC and a strengthening of Greek political coherence in the Italiote League under the dominance of Taras and with the incidental help of condottieri from mainland Greece. In the early 3rd century, however, a coalition was forged of both Greek states and indigenous Italic polities. This new and wider form of cooperation may have been triggered by Rome's rapidly increasing influence on southeast Italy. The creation of patently Roman communities at north-Apulian Luceria (314 BC) and Venusia (291 BC) in the border area between Apulia and Lucania may well have been perceived as Roman infringements on both the Lucanian and Italiote League's sphere of interest.

37 Ausculum is situated in north-Apulia (present-day Ascoli Satriano).

38 Like the hill forts of Samnium, these fortifications were often, but incorrectly considered to be sites without stable habitation (cf. Pontrandolfo 1994). 

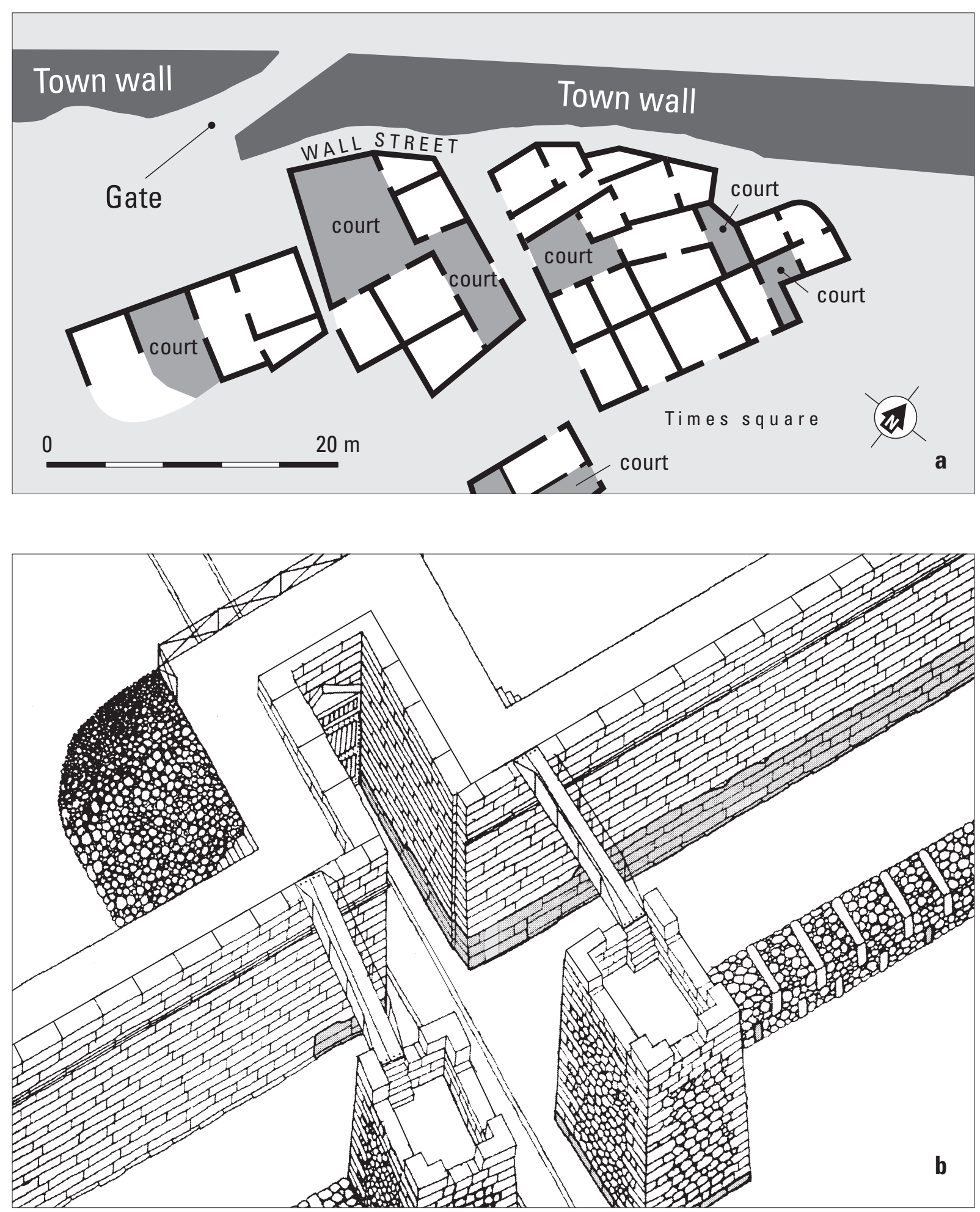

Fig. 6.4. Gates in southeast Italy: (a) Gate and northern quarter of the site of of Monte Sannace (central-Apulia), 4th-century; after Scarfì 1962; (b) Reconstruction of the East Gate at Vaste (Salento), 3rd century BC (adapted from G. Carluccio). 


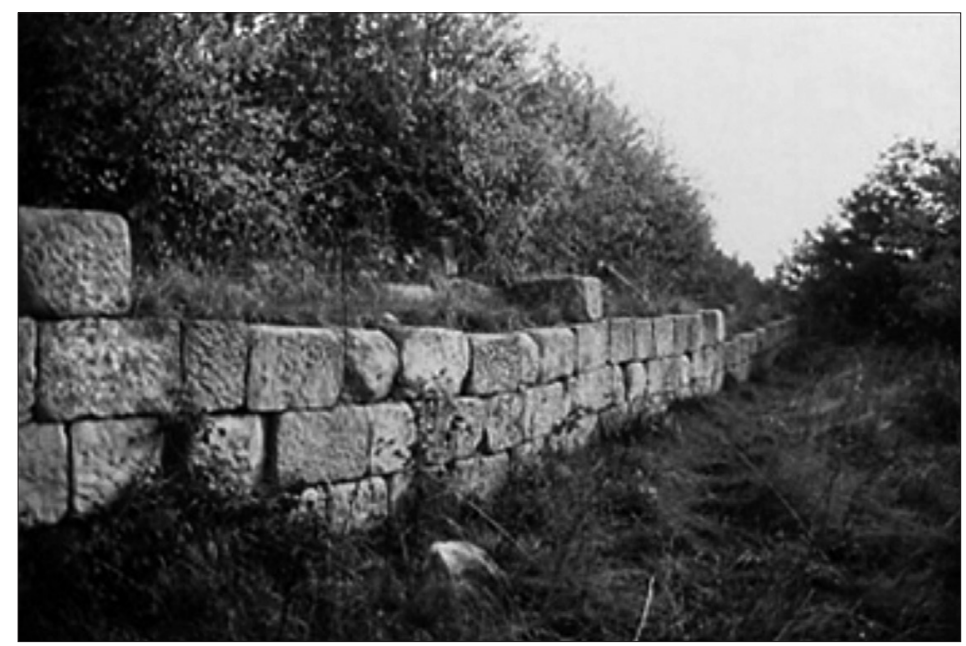

Fig. 6.5. Fortification wall of the site of Torretta di Pietragalla (Basilicata), later 4th century BC (archive Archaeological Institute VU University Amsterdam).

\subsection{A N D S C A E A N D S E T T L E M E N T}

The 4th and early 3 rd centuries BC were a period of great activity and great prosperity in all parts of southeast Italy. It was a time in which drastic changes occurred in many sectors of the societies living in that region. This observation does not only hold good for the wealthy Greek towns on the coast, but especially for the districts in which most people spoke Oscan and Messapic tongues. In the later 4th century BC new landscapes of both urban and rural character came into being here that differed enormously from those of 6th, 5th and early 4 th centuries BC.

The most conspicuous novelty in this respect is the sudden appearance of dozens of new fortifications. Imposing wall circuits made their appearance in many parts of southeast Italy. They continue to be visible in the landscape till the present day. Though Greek towns and a very limited number of non-Greek settlements in the southeastern Salento district had defences in stone as early as the 6th or early 5th century $\mathrm{BC}$, there was an astonishing boom in the construction of fortifications in the 4th century BC. Most of these stem in fact from the middle to later 4th century. Among these were, for instance, the newly built walls of Taras that enclosed the habitation areas and necropoleis at the eastern side of the town (fig. 6.2). But in non-Greek districts that bordered more or less on the chorrai of the poleis, the inhabitants of nearly each settlement of some substance started the laborious task of building walls that surrounded their settlement. ${ }^{38}$ On hills and mountains all over Basilicata fortifications were erected. By about the end of the 4th century BC some 33 Lucanian settlements had large and impressive wall circuits. ${ }^{39}$ Very similar architectural features began to appear, moreover, in central and southern Apulia. ${ }^{40}$ Whilst the Salento district, for instance, had only three or four large defended settlements in the 5th century BC, the number of settlements with walls that enclosed 25-30 hectares or more rose to about 25-26 around 300 BC.41

The construction of these imposing fortifications required an enormous input of time and effort. Such projects must have weighted heavily upon the local societies that produced them. Most of the newly fortified settlements had an estimated population of c. 3.000 to 5.000 inhabitants, children and women included. The building of fortifications required the quarrying, transport and fitting of thousands of tons of limestone blocks. As a rule these walls were several kilometers long, some five to six meters high and four to five meters thick. They had an inner and outer facing built in an isodomic or pseudo-isodomic technique. The blocks in the wall were mainly headers and stretchers of varying dimensions. The core of the wall consisted mostly of rubble and earth. For the average non-Greek

39 Tréziny 1983; Barra Bagnasco 1999, 49-51.

40 Fortifications in stone are conspicuous by their absence in northern Apulia in the 4th century BC. Here the highly dispersed settlements covering hundreds of hectares of the Iron Age and Archaic-Classical times continued to prevail to within the 3rd century; cf. Goffredo / Ficco 2010, 36 (Ordona, Ascoli Satriano).

41 D’Andria 1991; Lamboley 1991 and 1996a; Burgers 1998. 
settlement of south-Apulian Salento, for instance, some $20.000 \mathrm{~m}^{3}$ of limestone were needed for the construction of the fortifications. ${ }^{42}$ Since this district - often equated with ancient Messapia- had approximately 25-26 larger sites that were presumably walled in the period under discussion, the construction of these defences was a very notable effort indeed (fig. 6.3).

The entrances to these fortified settlements of southeast Italy were the gates. The vast majority of these were fairly simple, being basically passages through the new fortifications (fig. 6.4a). In the course of the 3rd century BC, however, Hellenistic warfare developed rapidly. This required the development of more intricate defences with towers, proteichismata and all. The best example of a more developed type of gate was excavated at Vaste (fig.6.4b). ${ }^{43}$

All these data suggest that the societies that produced these fortifications had very considerable surpluses at their disposal. As we have seen above, building activities of comparable intensity were carried out in Basilicata (fig. 6.5). Within the relatively short time of approximately 30 to 50 years these new, impressive and highly visible markers were created in the landscape over large parts of southeast Italy. These continue to be conspicuous to the present day and have been the sources of inspiration for many folk tales.

The construction of these enormous monuments in stone has often been linked with military affairs. They were believed to be an answer to a substantial, external threat. This threat was often thought to have come from the Greek condottieri invited by the Italiote League in the later 4th century or from the expanding Romans in the first half of the 3rd century BC. ${ }^{44}$ It should, however, be observed that the construction of large fortifications is a very time-consuming business and requires the creation of very substantial surpluses. Since moreover, it causes a heavy drain on local manpower, major fortification projects such as those carried out in many settlements of southeast Italy during the later 4th and early 3rd centuries BC cannot be responses to specific events or emergencies. The large scale appearance of town walls in southeast Italy in the late 4th century BC was the result of locally devised long term projects that required a considerable amount of planning and organization on the central level of the settlement. Therefore, the erection of fortifications is likely to point to structural changes in the societies of the region concerned.

It would certainly go too far to deny that the military aspect played no role in decisions to construct these town walls. The numerous settlements that were surrounded by such ring walls had grown prosperous by the late 4th century BC (see paragraph 6.5). Therefore, they were a potential prey to roaming bands and pirates stemming from competing neighbouring polities. The new walls certainly kept raiding parties away from the settlements with their wealthy elites and their rich stores. It is, however, very doubtful whether they were effective in larger conflicts involving armies of thousands of well-trained men (e.g. the troops of Alexander the Molossian or the Roman legions).

The 4th century fortifications, therefore, were more than just structures exclusively made to defend the settlement and withstand sieges. Since they were conspicuous monuments in the landscape, they were the pride of the local society and proclaimed the wealth and status of the settlement to both local inhabitants and outsiders. They were, moreover, an almost obligatory and indispensable feature indicating that the people who lived there made up a socio-political entity. It should, moreover, be noted that nearly all the numerous fortifications of southeast Italy were built at approximately the same time (last third of the 4th century BC). Obviously competition between indigenous settlements was also among the elements that resulted in these massive building activities. The fortifications, therefore,

42 The average length of a town wall in Salento, for instance, is slightly over $3 \mathrm{~km}$. With the blocks of the inner and outer facing having a width of $0.50 \mathrm{~m}$ each and a total height of $6 \mathrm{~m}$ the total of quarried stone amounts to c. $20.000 \mathrm{~m}^{3}$.

43 Lamboley 1996b and 1999, 89

${ }_{44}$ Lamboley 1996, 360-361. 


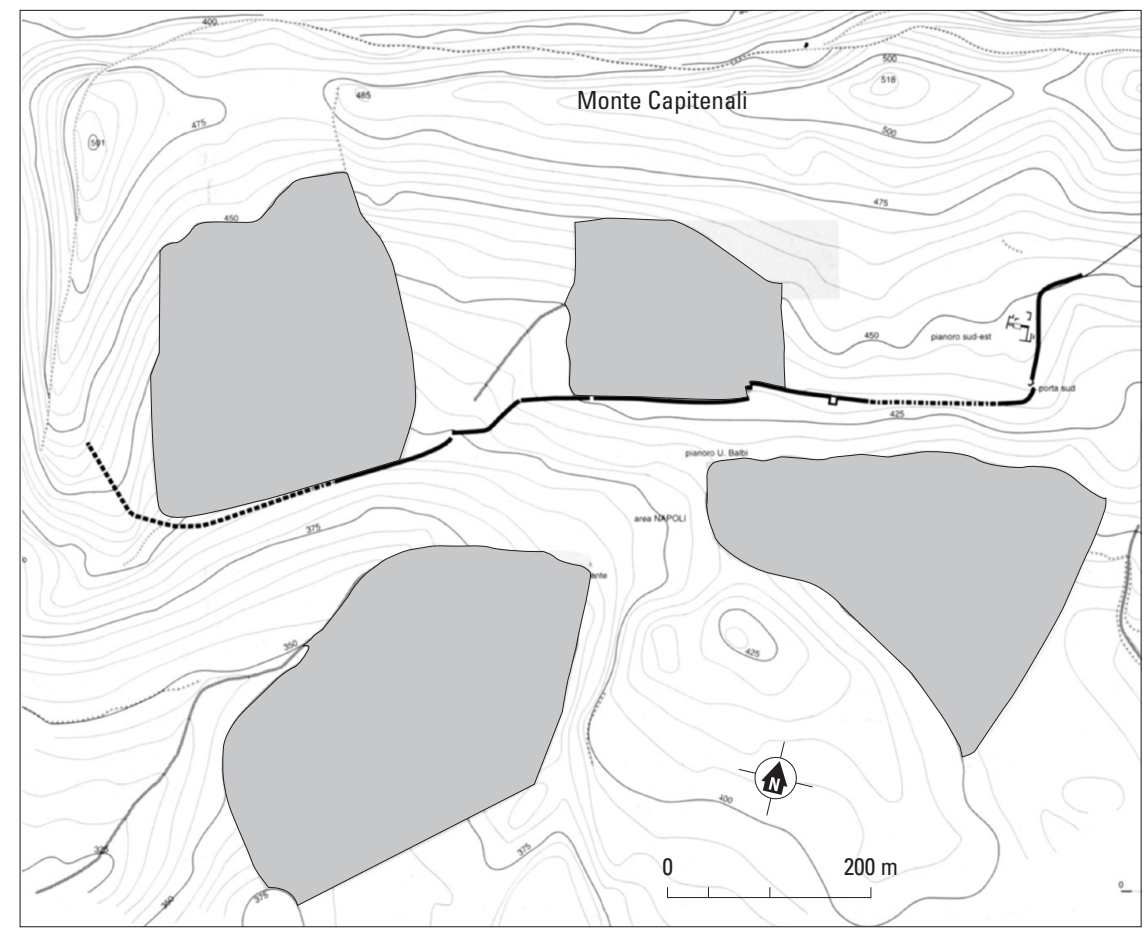

Fig. 6.6. The site of

Roccagloriosa with spatially separated settlement areas; 4th-3rd century BC; after Gualtieri and Fracchia 2001, fig. 70 .

were among the features that embodied the close cooperation of the inhabitants of the settlement and defined their shared local identity. Furthermore, they separated the habitation area from rural areas, marshes and forests that surrounded the settlement and kept raiding parties, wolves, lynxes, bears and boars away from the people, the household animals and the intra-mural fields.

The areas enclosed by the fortifications occur in many sizes. Generally speaking, the walled settlements of Apulia are larger than those in Basilicata. Whilst the intramural areas in 4th-century Basilicata vary between c. 25 and 60 hectares, ${ }^{45}$ the contemporary walled settlements of central and southern Apulia vary between c. 30 and 140 hectares. ${ }^{46}$ This difference may be partly caused by the character of these regional landscapes. In Basilicata these settlements occupy more or less flat mountain tops in fairly rugged terrain, offering only a limited space for prospective inhabitants and containing hardly any arable soils. Some of these were fairly densely inhabited ${ }^{47}$ In Apulia, however, the fortified settlements were on fertile soils in relatively flat areas. Here the settlements of the late 4th and early 3rd centuries BC probably enclosed both dispersed groups of dwellings and agricultural plots within their walls.

The differences in size between the fortified settlements of Apulia and Basilicata may also reflect differences in social and spatial organization. While the walled settlements in the Apulian Salento district were sometimes believed to have been similar in character to the Greek towns of southern Italy, their counterparts in Basilicata were often compared to fortified settlements in the Sabellic areas in central Italy. They were believed to have been mainly ceremonial centres of (sub-) tribal units. They were also thought to have been refuges since much of the population was believed to have lived in the surrounding areas. As a consequence of this, these 'Lucanian oppida' were thought to have had only a limited number of residents. These hypotheses, however, cannot be checked in the present state of

45 Barra Bagnasco 1999, 51.

46 D’Andria 1999, 109.

47 For a relatively densely inhabited settlement, see of Pomarico Vecchio in southeast Basilicata (Barra Bagnasco 1997). The site of Roccagloriosa (western
Lucania), however, consisted of various habitation nuclei. Only some of these were within the fortification walls. The steeper parts of the plateau had no habitation (cf. Gualtieri / Fracchia 2001). 

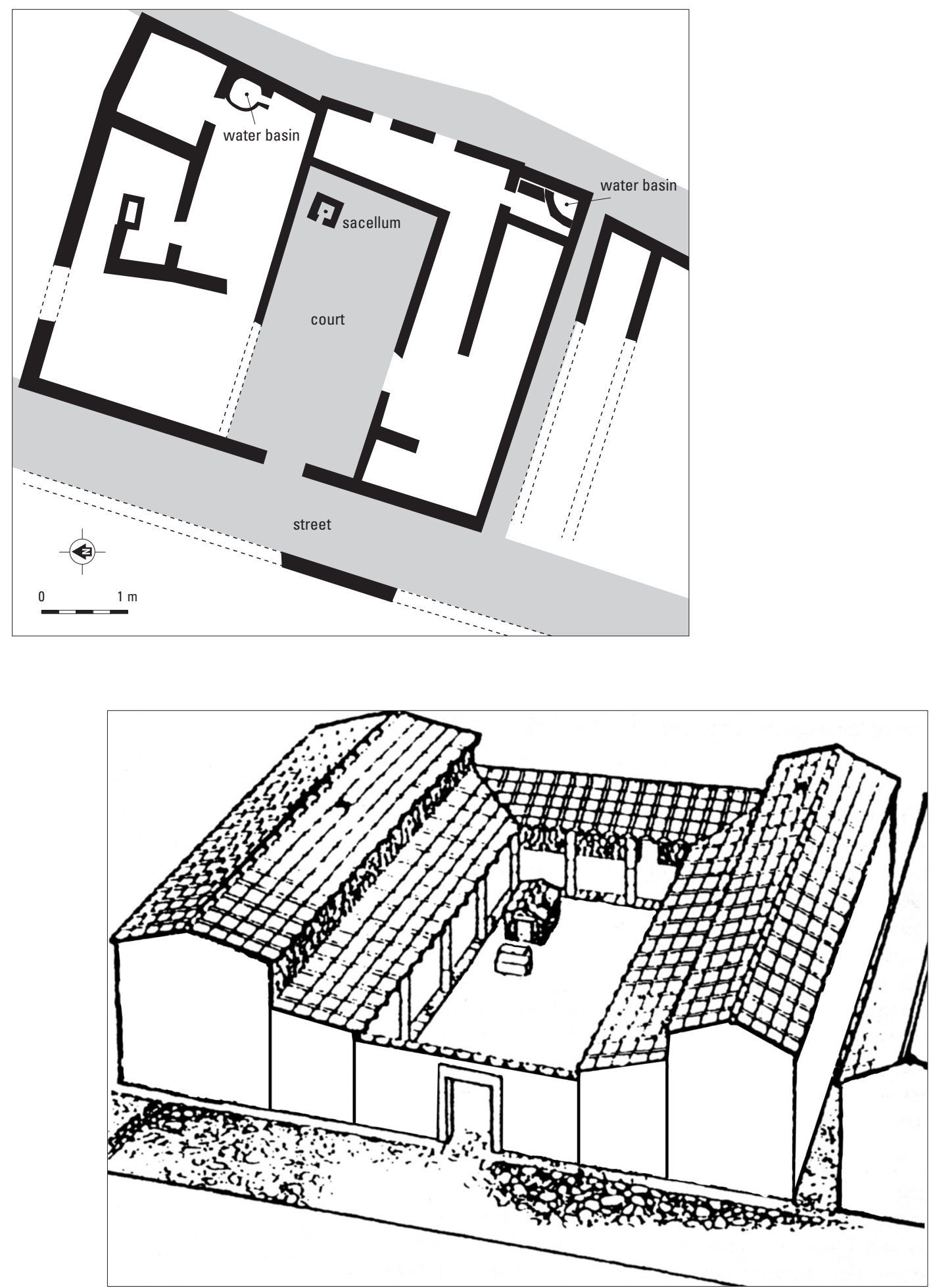

Fig. 6.7. Roccagloriosa, central area within the fortifications: houses (4th-3rd centuries BC); after Gualtieri and Fracchia 2001, fig. 49 


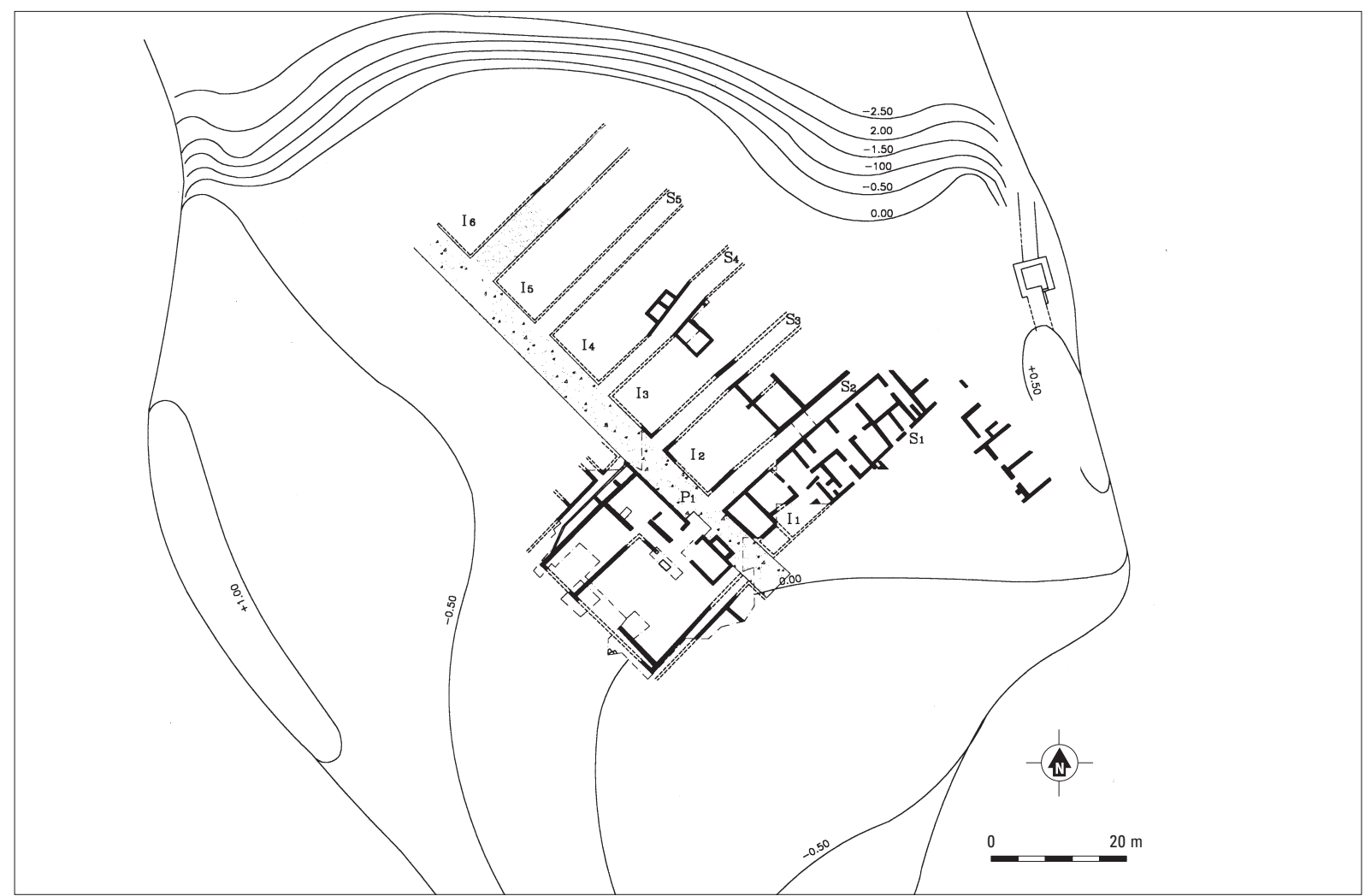

Fig. 6.8. Pomarico Vecchio (southeastern Basilicata): layout of the 4th-3rd-century settlement (after Barra Bagnasco 1997, tav. 5).

research. A thorough analysis of the function of these settlements is hampered by the fact that only limited parts of them have been excavated. Moreover, 'urban' surveys have been carried out in southern Apulia, but hardly any field work of this type has as yet been done in the fortified settlements of Basilicata. ${ }^{48}$ The cases investigated hitherto, however, seem to suggest that these fortified hilltop settlements were all true habitation centres. ${ }^{49}$

One of the most intensely studied fortified settlements of the Lucanian districts is the site of Roccagloriosa ${ }^{50}$ It is situated in the uplands of western Lucania only some $12 \mathrm{~km}$ from the Tyrrhenian Sea. It is in a dominant position on a nearly $500 \mathrm{~m}$ high mountain overlooking two river valleys. Both the settlement and the rural district surrounding the site have been objects of intense research involving both excavations and field surveys. ${ }^{51}$ As for the area enclosed by the defences, its extension is approximately 26-27 hectares of which only some 18 to 20 hectares can be used for human activities. ${ }^{52}$ The relatively flat intra-mural area which is fit for habitation, however, was not densely occupied with buildings. It contained various clusters of dwellings alternating with settlement areas showing only

48 For Torre di Satriano, see preliminary report in Osanna 2007.

49 Barra Bagnasco 1997; de Cazanove 2002; Gualtieri / Fracchia 2001

50 There is an ample bibliography on Roccagloriosa. For books with a more or less general character, see Gualtieri / Fracchia 1990, Gualtieri 1993 and Gualtieri / Fracchia 2001 Other sites on which there is good information are Satriano, (see, e.g., Holloway 1970,
Greco et al. 1988, Nava / Osanna 2001, Osanna / Sica 2005, Osanna 2009), Serra di Vaglio (e.g., Bottini 1990a; Greco 1980, 1982, 1991 and 1996), Pomarico Vecchio (Barra Bagnasco 1997) and Civita di Tricarico (de Cazanove 2002 and 2008).

51 Gualtieri / Fracchia 1990 and 2001

52 The defences are made up of a fortification wall and ravines. Part of the intramural area consist of rocky outcrops and steep slopes. 


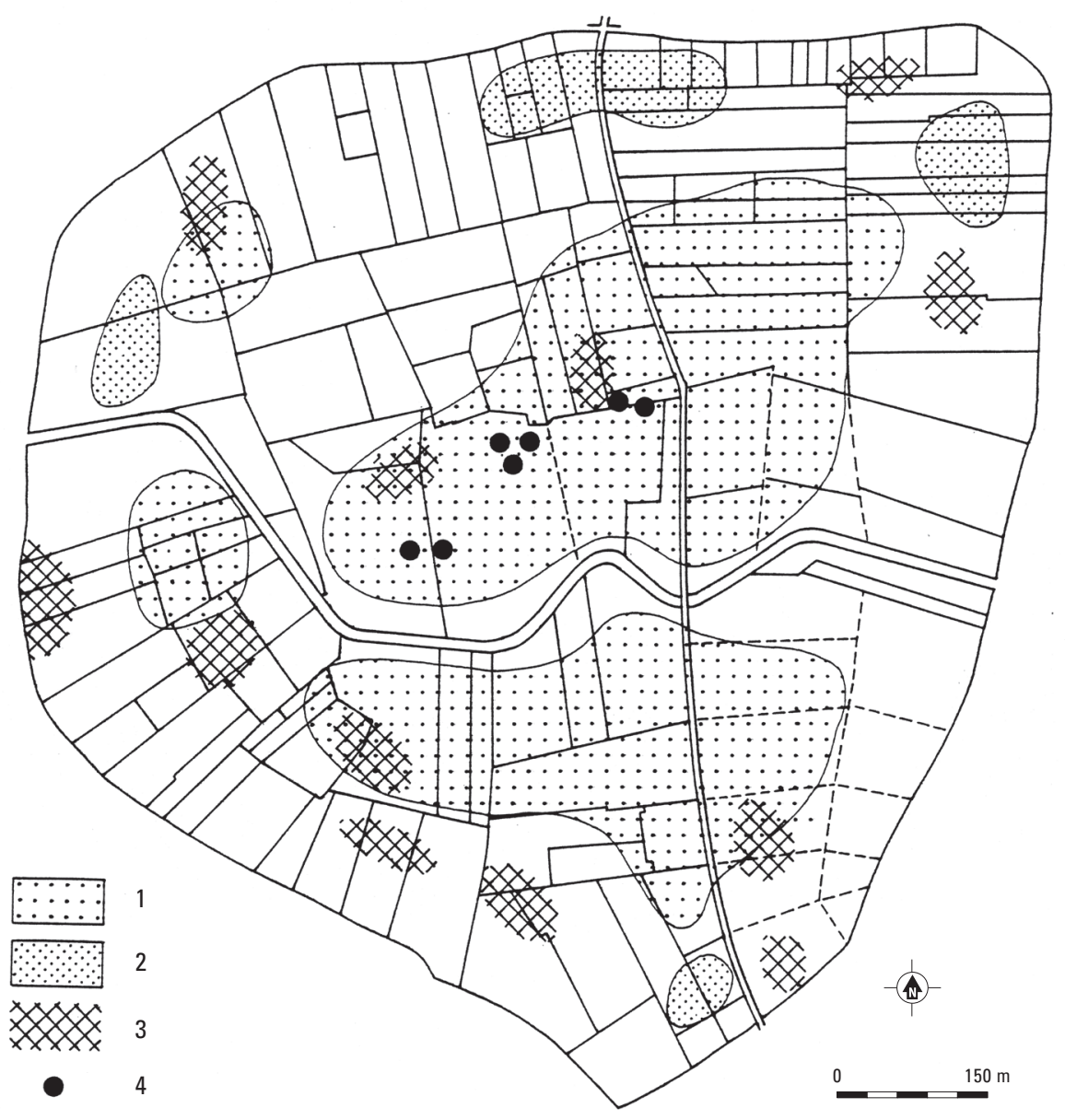

Fig. 6.9. Valesio (province of Brindisi): result of the urban survey for the 4th century BC. 1 habitation quarters; 2 storage areas; 3 burial areas; 4 architectural terracottas.

little sign of human activity. ${ }^{53}$ Some habitation areas of the settlement, moreover, were situated on a slightly lower plateau, decidedly outside the walled area. (fig. 6.6). There are, however, no differences between the habitation areas inside and those outside the walls. They all appear to consist of larger and smaller houses (fig. 6.7). These data may well suggest that each of these clusters was inhabited by a large family group or clan consisting of members of different rank.

Fortified settlements displaying dispersed groups of dwellings similar to that of Roccagloriosa were probably present in other parts of the uplands of Basilicata. ${ }^{54}$ In the hinterland of Metapontion in southeastern Basilicata, however, different forms of settlement are found. During the excavations at Pomarico Vecchio, some $25 \mathrm{~km}$ west of Metapontion, a fortified hill top settlement of a nucleated type has been excavated.$^{55}$ It occupied a plateau (altitude $415 \mathrm{~m}$ ) overlooking the surrounding countryside consisting of river valleys and hills. The layout of 4th- to 3rd-century Pomarico Vecchio displays an orthogonal grid pattern. The backbone of the layout consists of a $4.50 \mathrm{~m}$ wide main street and c. 3.00 $\mathrm{m}$ wide side streets separating insulae. These insulae have approximately the same width (c. $10.00 \mathrm{~m})$.

53 Gualtieri 1996, 303

54 Other candidates with a more or less dispersed form of settlement are Satriano, Serra di Vaglio (e.g. Greco
1991 and 1996) and Oppido Lucano (preliminary reports: Lissi Caronna 1972, 1980, 1983, 1990/1991).

55 Barra Bagnasco 1997. 


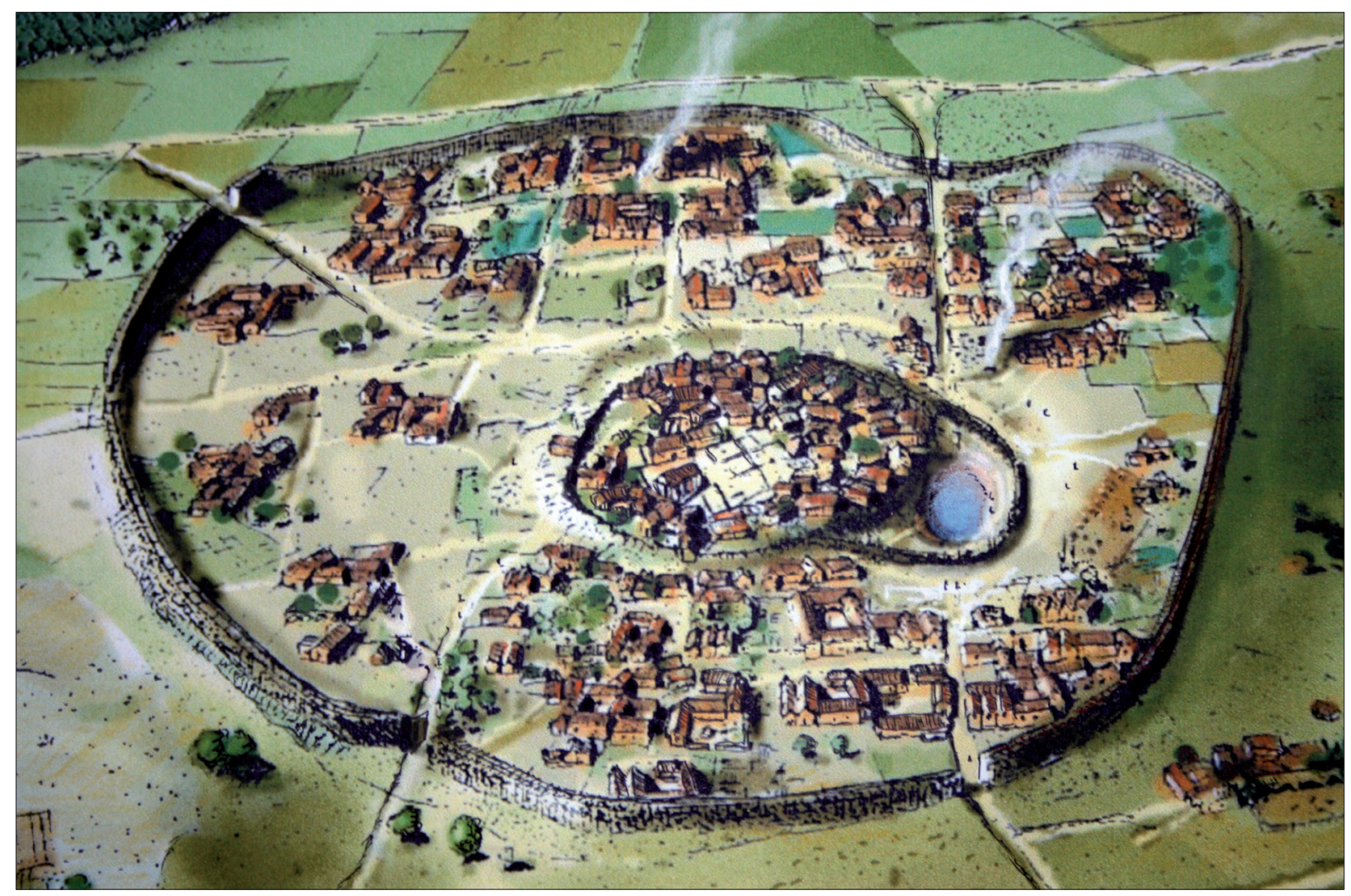

Fig. 6.10. Muro Tenente (Brindisi area, south Apulia): artist's impression of the settlement in the early 3rd century BC, based on auguring, urban survey and excavations at Muro Tenente (archive ACVU).

A larger building south of the main street having the width of two insulae, is believed to represent an aristocratic dwelling (fig. 6.8). ${ }^{56}$ This orthogonal layout with a wide main street (plateia) and more narrow side streets (stenopoi) displays close affinities with the layout of Greek towns of southeast Italy such as Taras, Herakleia and Metapontion. A town plan of comparable regularity can be found at Civita di Tricarico which - though definitely oriented on the Gulf of Taranto - is much closer to the mountainous heartlands of Lucania than Pomarico Vecchio. ${ }^{57}$

In the south-Apulian Salento district three fortified settlements of the 4th and 3rd centuries have been the subject of intensive research covering larger parts of the settlement area. These are the site of Vaste (c. $77 \mathrm{ha}$ ) in the southern tip of the peninsula, and the settlements of Valesio (c. 80 ha) and Muro Tenente (50 ha) which are both situated in the Brindisi district (northern isthmus area of Salento). Together these three sites have give a good impression of the structure and character of the 4th-3rd century settlements of this district. Whilst a substantial series of excavations has been carried out at various spots of intramural Vaste, both Valesio and Muro Tenente have been studied through both high intensity urban surveys and large scale excavations. ${ }^{58}$

56 The courtyard of the large building at Pomarico Vecchio contained a votive deposit, as did one of the aristocratic houses at Roccagloriosa (cf. Barra Bagnasco 1996, 229-232).

$57 \quad 56$ de Cazanove 2002 and 2006.

58 For concise report on Vaste, see Archeologia dei Messapi,
49-189; for substantial reports on Valesio see Boersma / Yntema 1987; Yntema 1993b and Yntema 2001; for Muro Tenente, see Burgers 1998. Urban surveys were also carried out at the fortified sites of Muro Maurizio and San Pancrazio, both situated in the Brindisi district (Burgers 1998). 

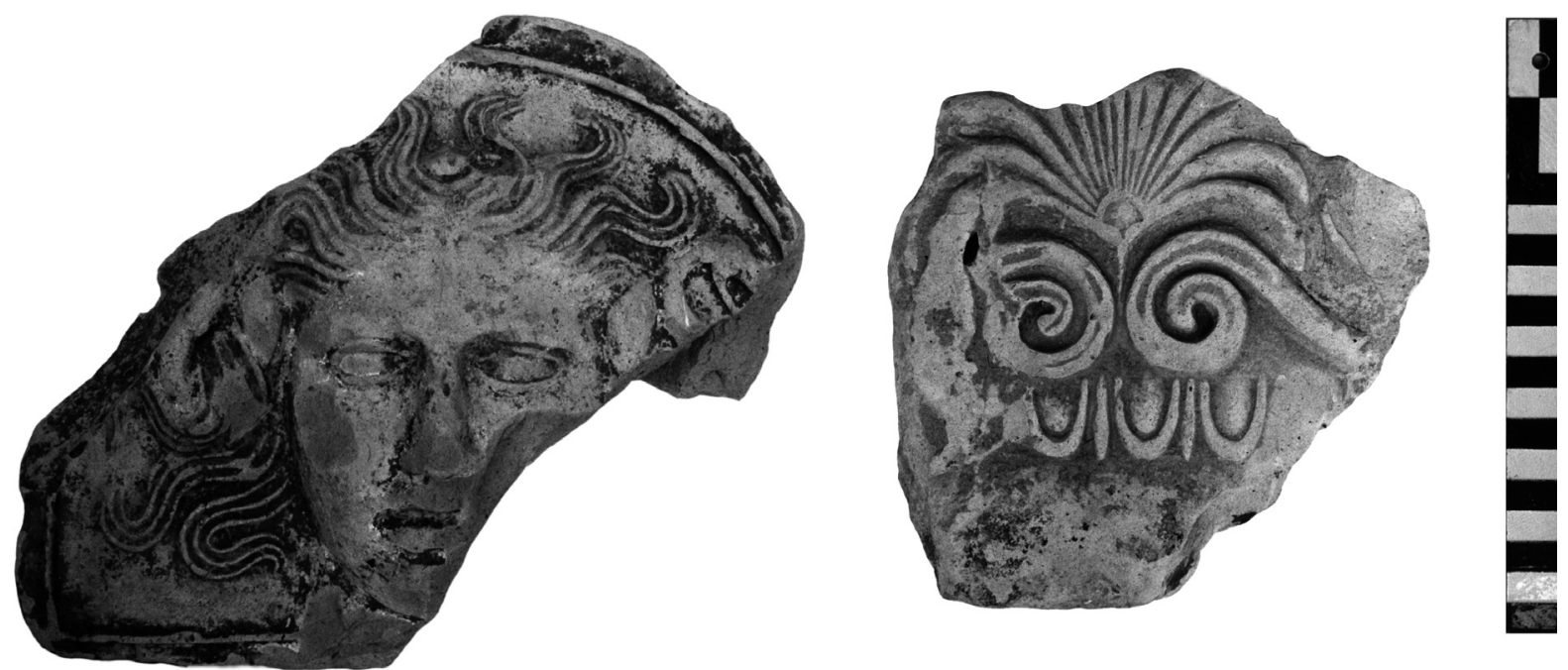

Fig. 6.11. Valesio (south Apulia): terracotta antefix and revetment plaque from centre of the site (4th-3rd century BC), archive ACVU.

The research carried out in the Salento district hitherto has shown that none of the intra-mural areas of the fortified settlements of the period under discussion was completely filled in with buildings. It appears that the fortified settlements of Salento were in fact more or less dispersed settlements in which clusters of habitations alternated with apparently empty spaces (fig. 6.9). At first sight the internal organization of these 4th-century settlements seems a continuation of the Iron Age situation in which the settlement consisted of dispersed clusters of huts. This observation is probably not correct. It appears that the various settlement clusters of the Salento sites were not inhabited by the complete family group. The field work at Muro Tenente, especially carried out to provide an insight into the spatial organization of this Salento settlement, demonstrates that the fairly densely inhabited centre of the settlement was the domain of the local elite. Here, each of the important local families had its dwellings and its elite cemetery. Craftsmen and farmers inhabited various spatially separated, more or less peripheral quarters in the area enclosed by the fortifications. It looks as if the settlement model in Salento was that of the pie chart: each of the local clans or family groups inhabited a chunk of the settlement pie (fig. 6.10). The leading families of the group lived in the very centre of the settlement, close to the dominant lineages of other local family groups. The dependant farmers and craftsmen lived in a habitation nucleus in the periphery of the walled area within the same chunk. The peripheral quarter excavated at Muro Tenente, moreover, constructed in the early years of the 3rd century BC, displays an orthogonal lay-out. The new houses here had approximately the same dimensions and were part of an insula (fig. 6.19). This suggests that the separation between the leading families of the settlement and the less privileged belonging to the same family group was a planned action that was carried out in a relatively short time. This all happened around $300 \mathrm{BC}$.

The organization of the fortified settlements of Lucania and Salento closely echoed the social structure of the local societies. It reflected both their tribal character and their social stratification, albeit in slightly different ways. It is, therefore, not correct to see these native walled settlements as second rate copies of the Greek poleis of southeast Italy. In both the Lucanian settlements of Basilicata and the complex settlements of the non-Greek groups of central and southern Apulia characteristic features rooted in the tribal character of these societies were retained during the 4th and 3 rd centuries BC. The great innovation at Muro Tenente was the separation between the tribal elite and the tribal farmers 


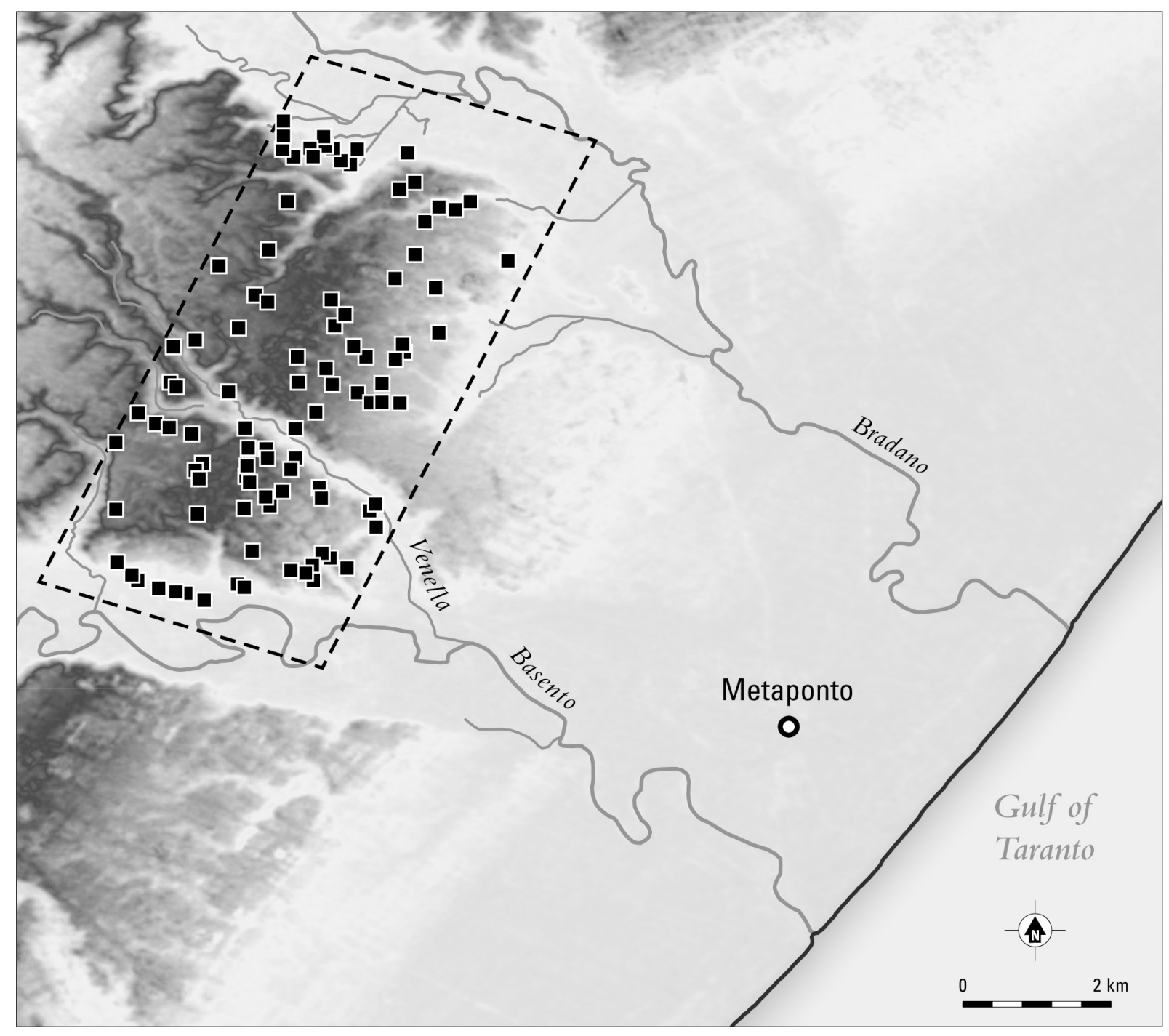

Fig. 6.12. Metapontion survey area: sites c. 300 BC. (after Carter / Prieto 2011).

and craftsmen. The various local families of high rank in the settlement stuck together and distanced themselves in a very literal sense from their kinsmen of lower rank. It is uncertain whether similar strict separations between elite and 'commoners' were also made in other settlements of Salento. As we have seen above the urban survey carried out at Valesio makes it quite clear that the site had various habitation nuclei in the 4th and 3rd centuries BC (see fig. 6.9). Since fragments of 4th century antefixes and other architectural terracottas referring to prestigious dwellings were collected exclusively in the central nucleus of the site (fig. 6.11), the spatial subdivision at Muro Tenente as described above may not have been unique. At Roccagloriosa in Lucania the local clans continued to inhabit their habitation cluster in the settlement as they had done before; the local elites were not separated from their kinsmen of lower rank (as in Muro Tenente), but lived in the larger houses within their own cluster.

The rather sudden appearance of many fortified settlements in large parts of southeast Italy during the 4th century $\mathrm{BC}$ is a phenomenon that cries out for explanation. As we have seen above, they have often been linked to the histoire évènementelle: they are currently seen as reactions to the activities of the condottieri invited by the Italiote League. But this explanation has been refuted above. They were constructed in the later 4th century BC because precisely at that time the various local societies of Basilicata and central and southern Apulia attained a level of organization and a level of cooperation 

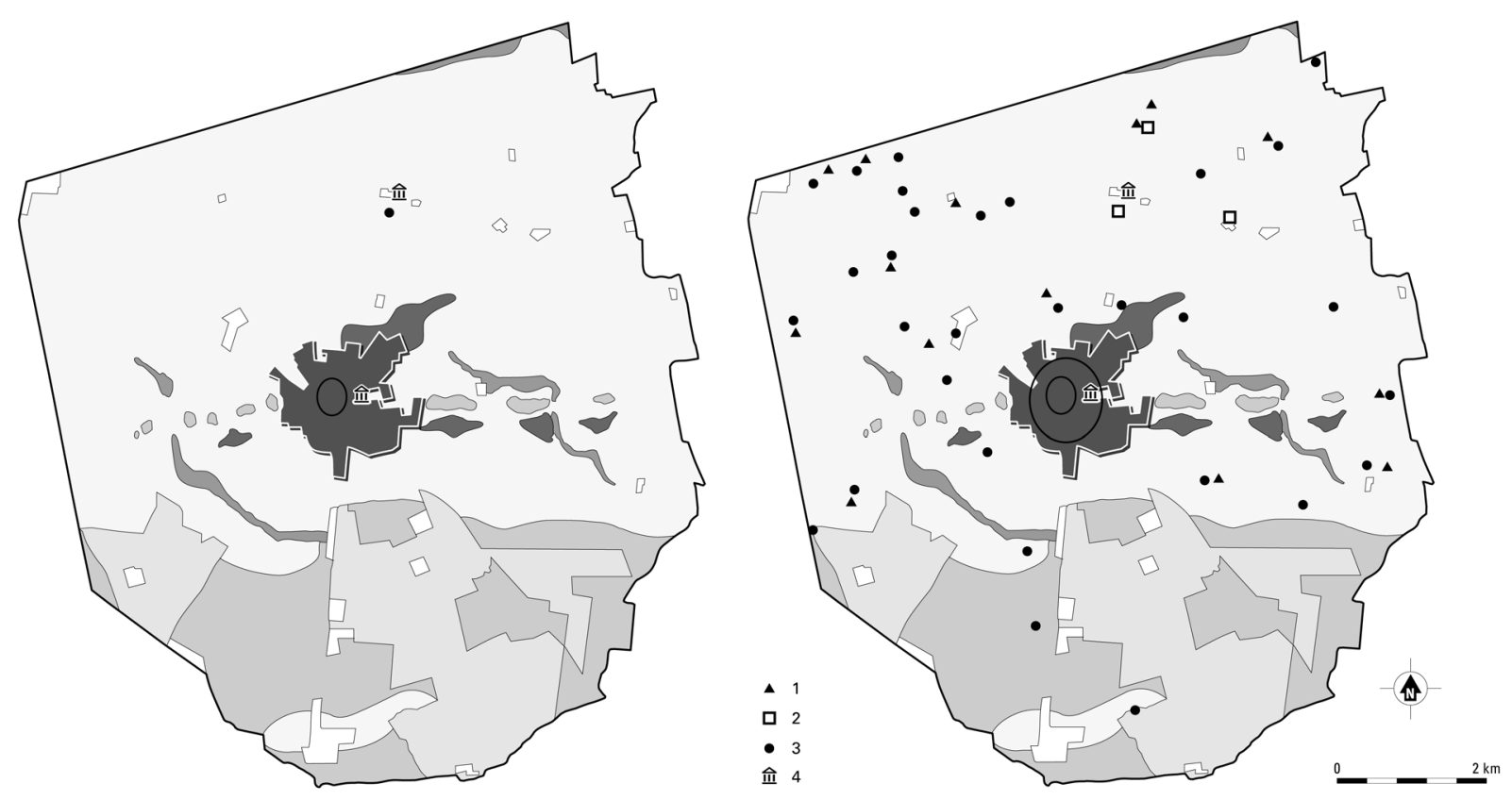

Fig. 6.13. Oria (Brindisi district): (a) Foci of human activity in the 6th and 5th century BC; (b) Explosion of rural settlement in the late 4th and early 3rd century BC: 1 rural necropolis; 2 hamlet; 3 isolated farmstead; 4 sanctuary.

between the local clans that is needed for such a collective enterprise. Furthermore, we shall see below that it was in that same period that they generated the means and the surpluses and could muster the working force that were all indispensable for such projects. Moreover the fortifications were the products of the need to stress various local identities, the need to loudly proclaim local pride and the need to compete with neigbouring groups.

At approximately the same time, the habitation areas began to expand markedly. This phenomenon has been mapped in detail for southern Apulia, ${ }^{59}$ but there are many signs that settlements were extended in a very similar way in other parts of Apulia and in Basilicata. ${ }^{60}$ In all the settlements that have been subject to urban surveys the scatters of later 4th and 3rd century objects are much denser and much larger than those of any preceding period. Part of this phenomenon may be due to the fact that the settlement ceramics of that period have a much better visibility and higher diagnostic values than those of preceding periods. ${ }^{61}$ A check at two sites in the Brindisi area (Valesio and Muro Tenente), however, has revealed that the peripheral scatters close to the defences contained no characteristic 5th- and early 4th-century pottery forms. The habitation quarters they represent were, therefore, newly created towards the end of the 4th or in the early years of the 3rd century BC. The exponential increase in formal burials from about $370 \mathrm{BC}$ onward seems to stress the same point: ${ }^{62}$ during the 4 th century $\mathrm{BC}$ there was a remark-

59 Yntema 1993b, Burgers 1998.

60 For instance, Gualtieri / Fracchia 1990 and 2001.

${ }^{61}$ The diagnostic Apulian Black Gloss wares became very common in household contexts of the non-Greek areas of southeast Italy from the later 4th century BC onward. Before than time the usual household assemblage of ceramics consisted exclusively of impasto wares (pithoid storage jars), coarse wares (cooking pots), plain wares (jugs, basins) and banded wares (lekanai, hydriae, stamnoid vessels, cups) which are all poorly diagnostic.

62 The demographic growth was not so enormous as the rapidly increasing quantities of burials seem to suggest. There is reason to assume that in the 4th century, especially in the indigenous districts of southeast Italy, a percentually higher number of members of the local groups received a formal burial than in the 6 th and 5 th centuries BC. 

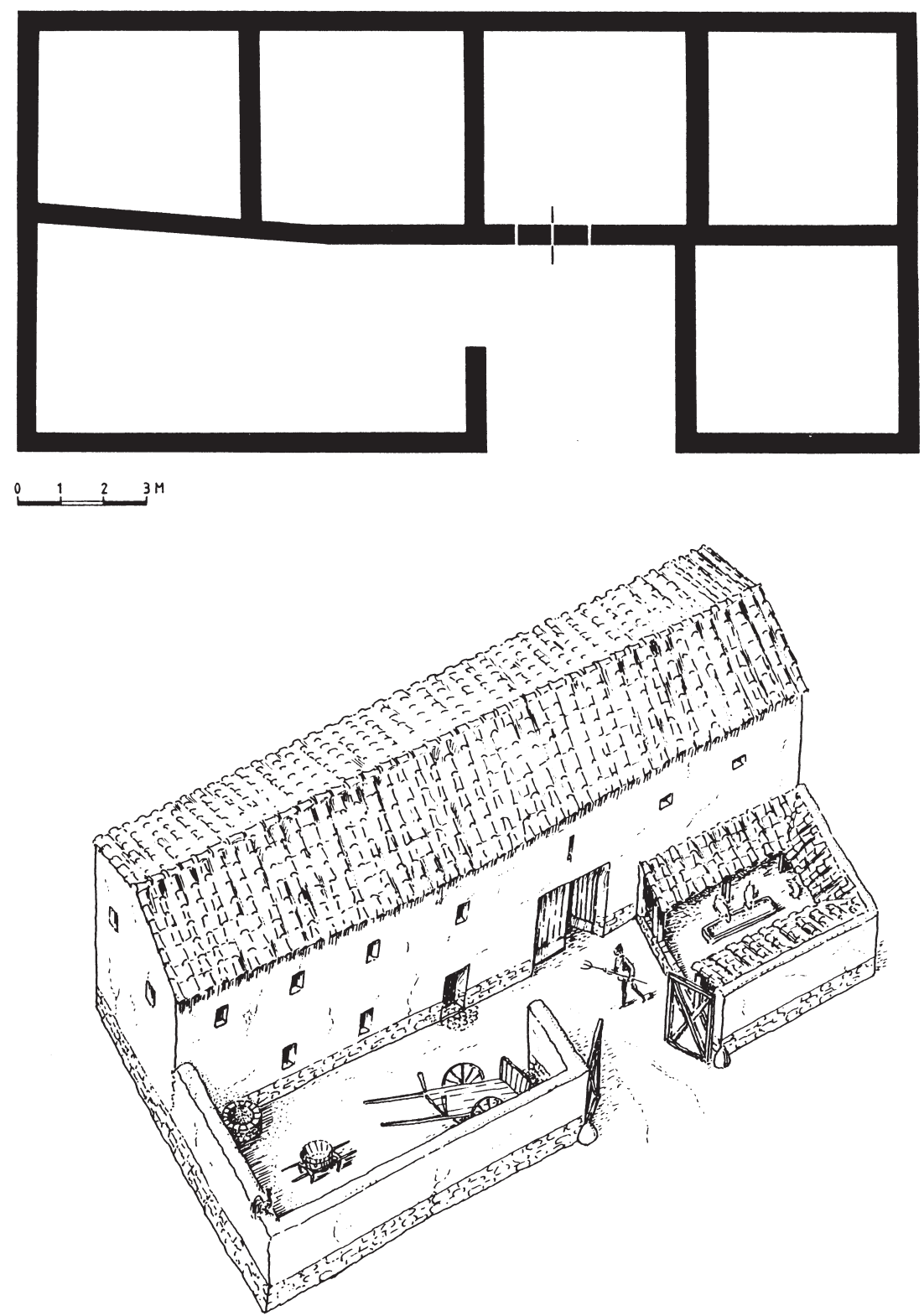

Fig. 6.14. Vaste (south Apulia). Early 3rd century farmstead: ground plan and artist's impression.

able demographic growth. It seems particularly evident in the native districts of southeast Italy. But a rapid extension of settlement areas and a very substantial increase in burials can also be observed in the Greek poleis of the same region. It may be concluded that from the 4th century BC onward southeast Italy sustained a much larger population than in any preceding phase of its history.

We have seen that both in Apulia and in Basilicata new, more or less urban landscapes were created by the large scale construction of defences and new, sometimes fairly regular lay-outs of the rapidly expanding settlement areas. ${ }^{63}$ These contained the large houses of the elite, the dwellings and workshops of craftsmen and the farmsteads of tribal farmers. The most astonishing novelty in the use of

63 These non-Greek walled centres are often called 'proto-urban' settlements, since the social structure of the local society and the spatial organization reflecting this structure is likely to display overtly tribal features. 
space was the birth and expansion of rural landscapes all over southeast Italy. It has been observed in the preceding chapter that inhabited countrysides were created in the territories of the Greek towns during the 6th century BC. In the 4th century BC, however, the number of farm sites increased notably in the territory of Metapontion. ${ }^{64}$ It was in the later 4th and 3rd centuries that rural activities were at their most intense there (fig. 6.12). Similar patterns have been discovered for the chorrai of Kroton and Taras. ${ }^{65}$ The present evidence, therefore, seems to suggest that the 4 th and 3rd centuries BC were a period of great agrarian flourishing for the poleis of southeast Italy.

The 6th-century creation of an intensely inhabited and exploited countryside was characteristic only of the coastal settlements that saw themselves as Greek poleis. It has been observed in chapter 5 that a similar phenomenon is conspicuously absent from districts inhabited by people who spoke Messapic and Oscan languages. The non-Greeks are believed to have cultivated a halo of fields that surrounded the settlement areas during the 6th, 5th and first half of the 4th century. In the later 4th century BC, however, all of a sudden isolated farmsteads and hamlets consisting of three to five farmsteads begin to appear at spots which are three to five kilometers away from the nearest non-Greek settlement. This rural expansion started between 330 and 300 BC: the earliest finds from these small rural sites almost invariably date to the late 4 th or early 3 rd centuries BC.

These small rural settlements have been discovered during intensive field surveys from the late 1970s onward.$^{66}$ The phenomenon was not confined to one or two districts; it was exceptionally widespread and can be observed in almost every nook of southeast Italy. Examples of such rural settlements have been traced from the valleys surrounding Roccagloriosa at westernmost outskirts of Lucania ${ }^{67}$ to the border area between Basilicata and Apulia ${ }^{68}$ the Salento peninsula ${ }^{69}$ and northern Apulia. ${ }^{70}$ Their number, moreover, is amazingly large. Whenever intensive field surveys have been carried out, dozens of farm sites have turned up with an average of at least one per $\mathrm{km}^{2}$ of arable land. If we extrapolate these survey results over the whole region discussed here, thousands of farmsteads must have been constructed in a rather short period of 30 to 50 years. On the basis of the finds one may assume that these were permanently inhabited. All of a sudden, an explosion of small rural settlements took place in the late 4th and early 3rd centuries BC. It resulted in an intensely cultivated countryside littered with farms (fig. 6.13 and 6.14).

The farms were not the only trace of human activity in the areas between the various fortified settlements of the native districts of southeast Italy. High intensity field surveys have also produced traces of rural necropoleis. Only one or two of these have been excavated in a more or less systematic manner. ${ }^{71}$ They were probably never large: each of these may have contained some 15 to 25 tombs and spanned a period of three to four generations. ${ }^{72}$ They confirm the stable and permanent character of the rural

64 Carter 1998b, 2001 and 2006.

65 Carter / D’Annibale 1985; Burgers / Crielaard 2007 and 2011 .

66 The scatters are mostly small (usually between $900 \mathrm{~m}^{2}$ and $2000 \mathrm{~m}^{2}$ ). Among the finds are fine wares (black gloss wares), thick walled plain wares (mortars, large jars and container vessels) and more thin-walled plain wares (jugs, pitchers), cooking wares (stew pots, casseroles), roof tiles, limestone blocks and large fragments of olive and wine presses.

67 Gualtieri / Fracchia 2001.

68 Cf. Small et al. 1998, 365, Small 2001, Small / Small
2005.

69 Boersma et al. 1991, Yntema 1993a, Burgers 1998, Burgers / Crielaard 2011.

70 Volpe 1990, Goffredo 2010, Goffredo / Ficco 2010.

71 For a rural necropolis in the Oria-Francavilla area, see Marinazzo 1980.

72 They currently date between c. 330/320-250/230 BC. In the second half of the 3rd century BC there is a major shift in the funerary customs. As a result of this, the burials of a large part of the population can no longer be traced. 


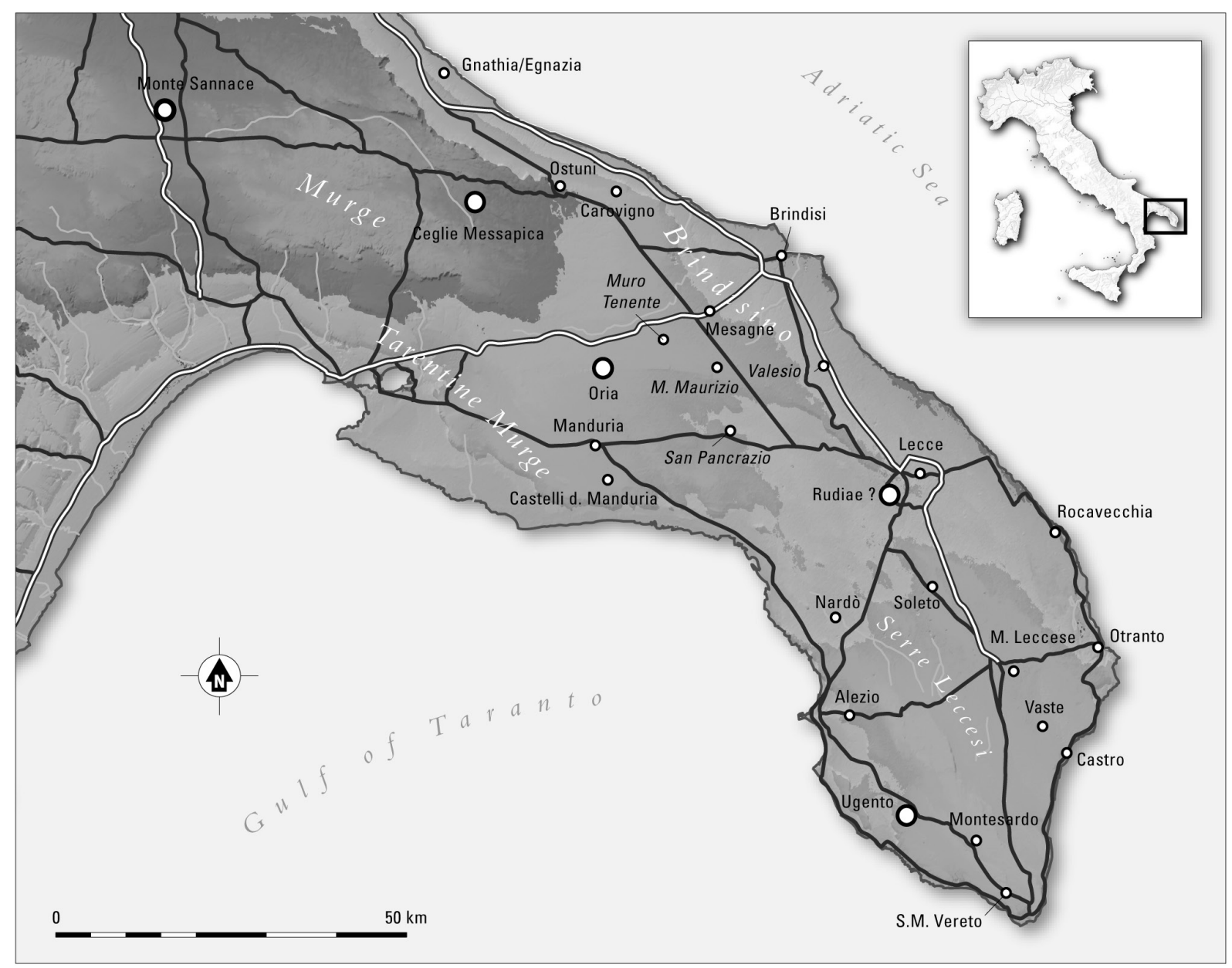

$<25 \mathrm{~m} \quad 25-400 \mathrm{~m} \longrightarrow>400 \mathrm{~m}$

Fig. 6.15. Salento district (south Apulia): major tribal centres and fortified settlements of lesser importance in the later 4th century BC.

settlements. People actually lived, raised families and died at these farmsteads. They were mainly agriculturalists. Remains of wine and olive presses and fragments of dolia collected at many of these sites indicate that the family processed and even stored products coming from their fields in their farm. Obviously the risk of being raided by a band from a neighbouring settlement soon after the harvest had been brought in, was not particularly great.

These drastic changes in agricultural practice had enormous effects on the landscape in many parts southeast Italy. Whilst many settlements had been surrounded by fields before the later 4th century $\mathrm{BC}$, fertile areas several kilometers from the settlement were now taken into cultivation. Since these were covered with natural vegetation, they had to be reclaimed. In the relatively short period of 30 to 50 years substantial parts of southeast Italy underwent a major transformation. Manmade landscapes increased drastically at the coast of wild nature. Before the middle of the 4th century BC each indigenous settlement had been a manmade island of dwellings and fields in a sea of forests and shrubbery (natural landscapes with traces of human influence). From c. 330 onward, smaller and larger patches of completely manmade landscape consisting of one or more dwellings and tilled fields began to appear in many places in the landscape. The distance between the various foci of human activity in the landscape shrank enormously. In the Brindisi area in northern Salento, for instance, the settlements had been 
seven to ten kilometer apart before 330/320. With the birth of the farmstead landscape in the late 4th century, the distance between settlements (farmsteads, hamlets, fortified centres) was often no more than a few hundred meters. Although large patches of wood survived in various areas (surveys have also recorded completely 'empty' areas) ${ }^{73}$ substantial parts of the environments of southeast Italy had now been turned into human landscapes of fields and farmsteads. ${ }^{74}$

The creation of this manmade, rural landscape in southeast Italy during the late 4th and earlier 3rd century BC consisting of probably thousands of farmsteads was an immense effort. It resulted in the felling of ten thousands of trees, ${ }^{75}$ the removal of trunks and burning of shrubbery and the construction of the farmhouses with their annexes. These actions took much time and considerable manpower. When they could be carried out without totally unbalancing the local societies (as seems to have been the case), they could be carried out exclusively by groups that were very well organized and had amassed very considerable surpluses indeed. This observation gains in strength when we note that the large scale reclamations were more or less contemporary to the building of equally labour intensive fortifications and the construction of new settlement areas.

Both the suddenness and the large scale of the changes suggest that the driving force behind these actions was usually not the individual decision or the personal choice of the Lucanian or Messapian farmer. There was a more central drive behind these massive reclamations of land. Like the construction of the defences, moreover, it was an enterprise in which necessarily a substantial part of the population participated: clearing substantial patches of forest and preparing the soil for agrarian purposes is a laborious task. That does not mean that this expansion of the agricultural area of the settlement was actually an effort in which the whole community living in a fortified settlement must have participated. Since local clans were probably important in the non-Greek districts of southeast Italy, local elite families with their substantial wealth and their large local clientele may well have taken the initiative. Each of the three to five local family groups or clans extended its farmland by reclaiming terrains in patches of wild nature on which they believed to have a justified claim. The local elites may well have been inspired by the example of Greek aristocrats who owned large patches of land in the territories of their Greek city states and extracted substantial wealth from these possessions. The new farms of Lucania and Apulia could well have been manned by dependent farmers who belonged to the same clan group that initiated the reclamation of a new patch of fields. If this was indeed the case, the local clan group was the owner of the newly reclaimed terrains in the purely technical sense. The main profits, of course, went to the elite family that headed that particular group.

In the preceding chapter on the 6th and 5 th centuries $\mathrm{BC}$ we have seen that a very distinct settlement hierarchy developed in the territories of the Greek speaking coastal towns of southeast Italy. Each polis had one urban centre, some hamlets and dozens of isolated farmsteads. This hierarchy was the result of large scale reclamation of new areas for agriculture and landscape infill that took place during the 6th century BC. When the same activities were carried out in the non-Greek areas of southeast Italy in the course of the 4th century BC, a similar manmade landscape was created here. This means that the settlement hierarchy in Basilicata and in central and southern Apulia became much more complex. Whilst it consisted of tribal centres and settlements of probably lesser importance during the 6th and 5 th centuries BC, the creation of an inhabited countryside during the 4th century BC added two new types of rural settlement: the isolated farmsteads and the hamlets consisting of a few farms. Major

73 Another indication for the survival of woods is that the 4 th and early 3 rd century bone samples have some $5 \%$ percent of red deer (Cervus elaphus). This percentage differs little from those of the bone samples of the 8 th, 7th, 6th and 5th centuries BC.

74 Attema et al. 1998.

75 These were predominantly oaks, beeches and ashes (see Veenman 2002). 

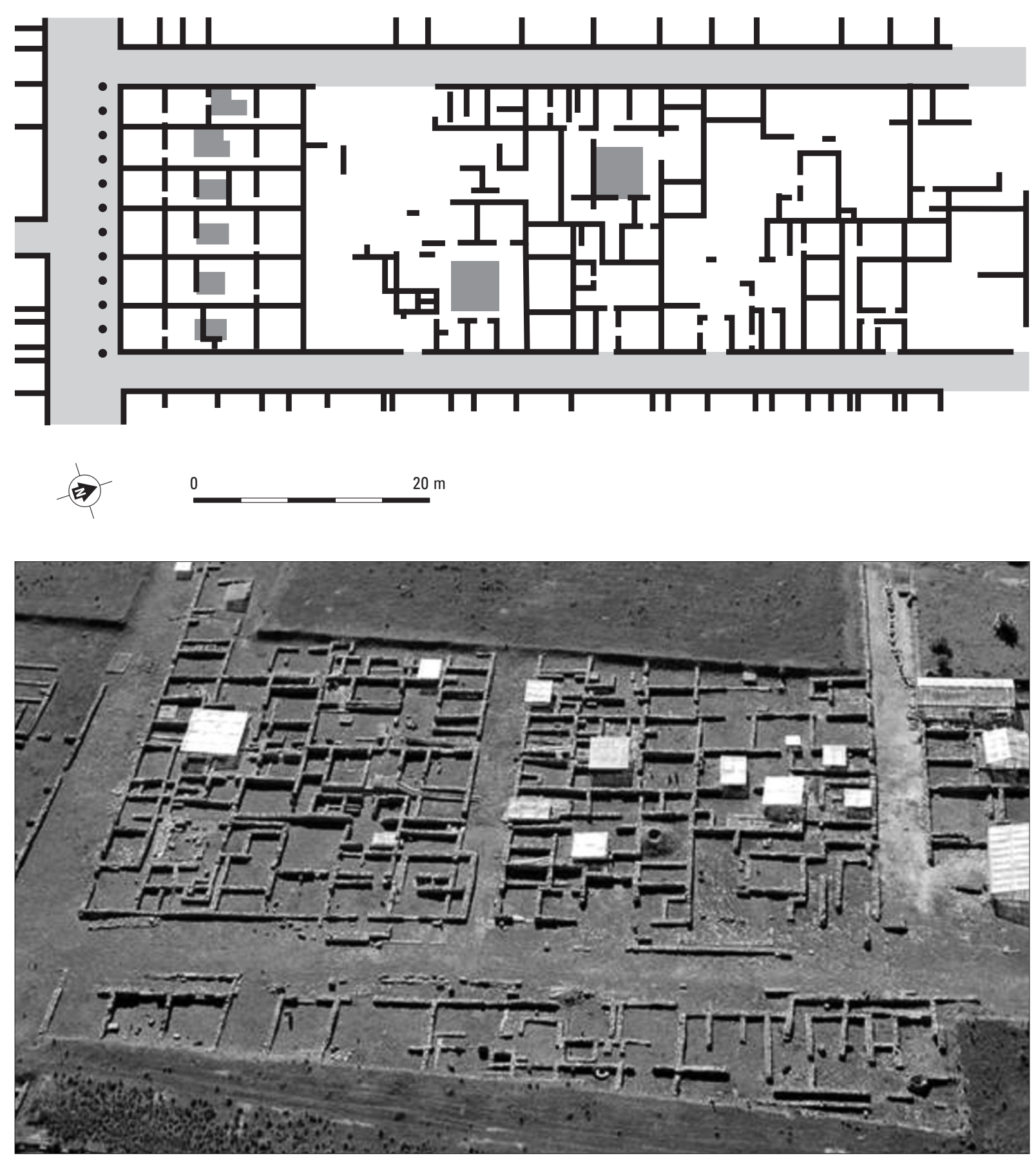

Fig. 6.16. Plan (after Giardino 1996) and aerial photograph (courtesy tourist office) of western quarter of Herakleia in Lucania.

tribal centres which were sometimes fortified as early as the late 6th or early 5 th century BC, probably continued to be the highest echelon in the settlement hierarchy. It is, however, doubtful whether they completely retained their dominant position when many dependent settlements of formerly lesser importance started building town walls. As we have seen, these fortifications stressed local identities and may have weakened identities shared by the whole tribe focusing on a particular tribal centre. In principle, moreover, they enabled these newly walled settlements to follow a somewhat more independent course in political matters. Probably, the great tribal centres continued to be the largest and most important settlements. They continued to play a central role in various tribal ceremonies and 


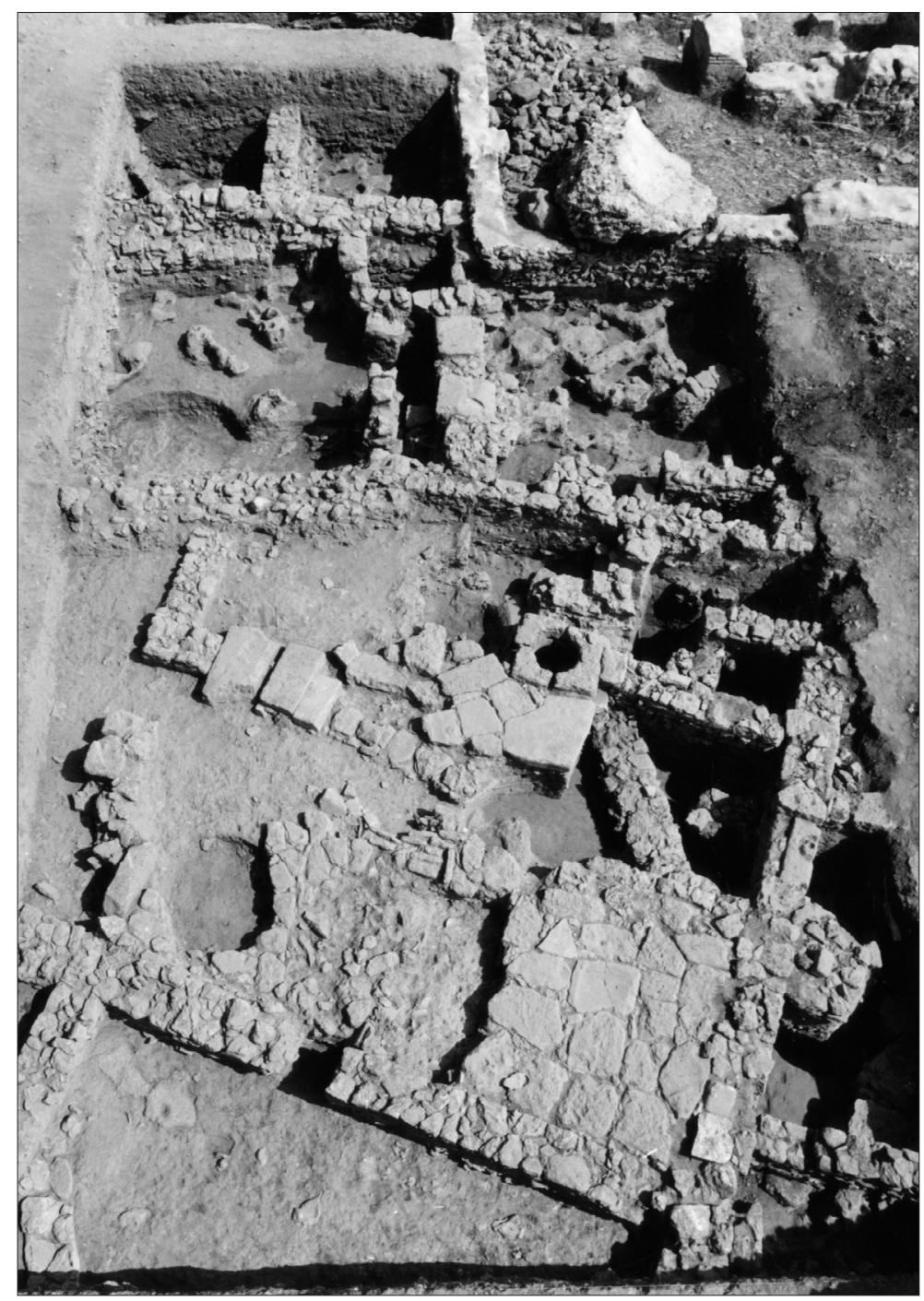

Fig. 6.17. Valesio (Brindisi area, south Apulia); stone plinths of houses of the $3 \mathrm{rd}$ century BC. Archive ACVU.

continued to be the base of the paramount chief. The presence of very large buildings often identified as princely residences in these major settlements seems to confirm this supposition. An enormous 4th-century elite dwelling was excavated at the tribal centre of Serra di Vaglio (upper Basilicata; see below), while Oria which had more or less the same status on the Salento isthmus is said to have had a 'royal palace'. ${ }^{76}$

In the later 4th century BC, therefore, a settlement hierarchy came into being in the non-Greek areas of southeast Italy that displays similarities to that found in the Greek states on the coast. It consisted of large tribal centres and fortified settlements of considerable complexity depending in some way on these large centres (fig. 6.15). In addition to these there were hamlets consisting of three to six farmsteads and large numbers of isolated farmsteads. These rural settlements all depended on the nearest walled settlement. This was the agrarian centre of the territory controlled by the clans living in that fortified settlement.

The developments sketched above, however, did not occur in every part of southeast Italy. Walled towns and settlement systems displaying a strong hierarchical character were absent in the two 'Daunian' districts of northern Apulia. Here the character of important settlements such as Canosa and Arpi hardly differed from that of the Iron Age and Archaic-Classical times. They continued to be large, highly dispersed settlements covering hundreds of hectares and having varying densities of habitation (fig. 4.3). As late as the second half of the 4th century BC they consisted of various, spatially separated habitation clusters. Each of these consisted of houses and/or huts probably surrounded by yards. These loose clusters inhabited by different clan groups, alternated with animal compounds and tilled fields. In was only in the course of the 3rd century BC that more or less dense clusters of habitations came into being in the settlements of north-Apulia which started to display a slightly more urban appearance. ${ }^{77}$

76 For the large building at Serra di Vaglio, see below; the presence of a royal palace at Oria (basileion) is mentioned by the geographer Strabo (Geography VI.3.6)
77 Mertens 1979 (Ordona), Goffredo 2010 (Canosa), Gofredo / Ficco 2010 (Ascoli Satriano). 

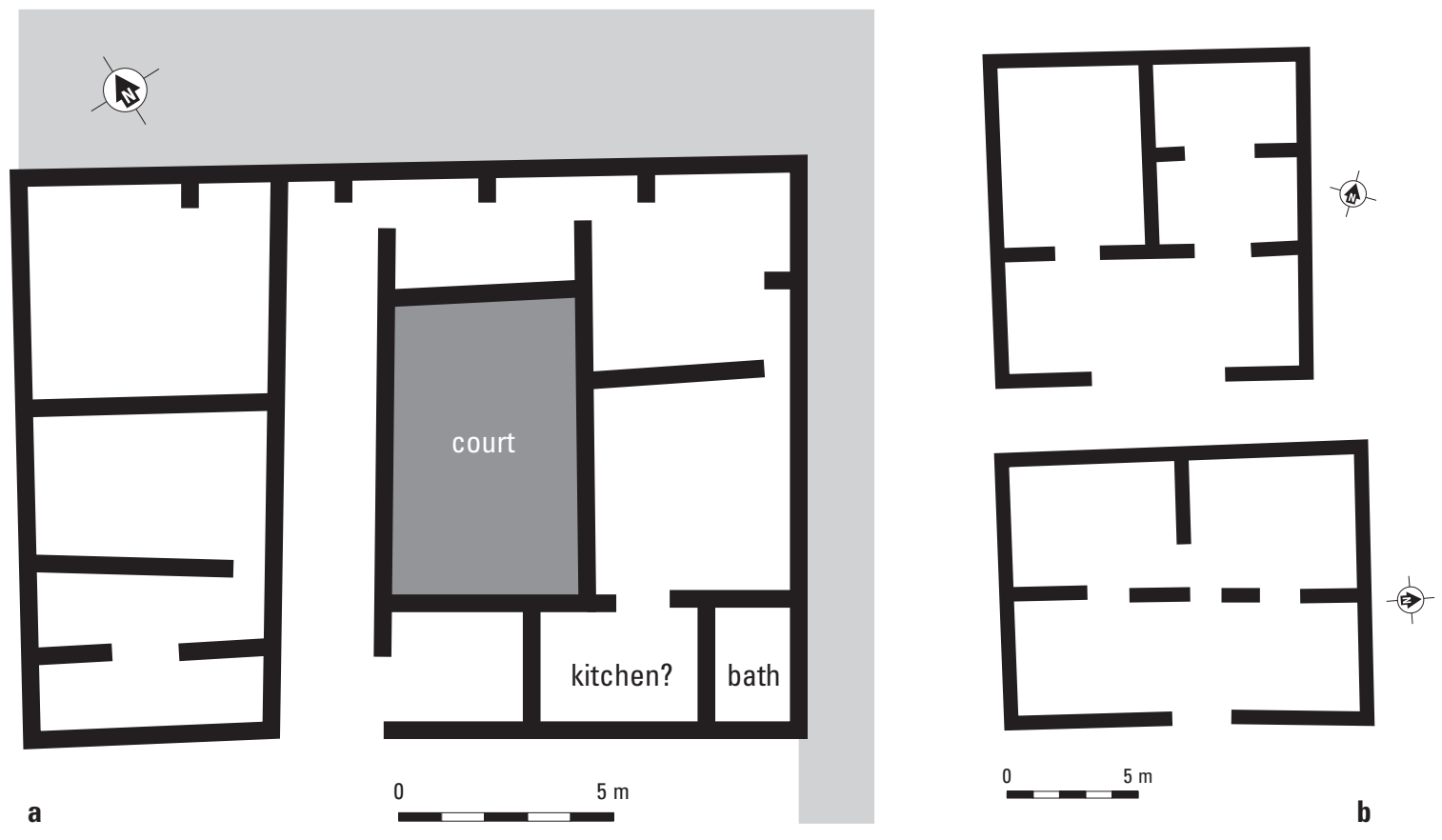

Fig. 6.18. Houses in 4th-3rd century in southeast Italy: a courtyard house at Herakleia; b three room houses from Monte Sannace, central Apulia.

In ranked societies dwellings often reflect in some way the status of their occupants. This almost general rule also applies to 4th- and 3rd -century BC southeast Italy. In order to trace differences in contemporary house architecture however, substantial parts of settlements have to be excavated showing the housing of both the elite and the less privileged. Such activities were carried out in only a limited number of cases. The sample of dwellings on which the present observations are based, therefore, is fairly small.

The most elaborately studied case of 4th- and 3rd-century house architecture in a Greek speaking town of southern Italy is Lokroi Epizefyrioi which is definitely outside the area discussed in this book. ${ }^{78}$ The quarters excavated there may well give a good impression of the habitation areas that existed in Taras, Metapontion, Herakleia and Thourioi. Similar quarters have indeed been found at Herakleia where they are relatively well preserved. Here, they invariably display a regular layout with larger streets (plateiai) and smaller ones (stenopoi) meeting at right angles. Identical layouts were present at Taras, Thourioi and Metapontion. These define insulae having houses of varying dimensions and various degrees of luxury (fig. 6.16). In Herakleia most houses have a courtyard, whilst a few larger specimens appear to have a peristyle or a large central court. ${ }^{79}$ The rooms of the Herakleia houses are invariably arranged around or alongside the open space in a way that is echoed at Lokroi. ${ }^{80}$

Similar houses consisting of a handful of rooms giving onto a courtyard are found all over southeast Italy ${ }^{81}$ They occur in many different dimensions and are present in both the towns of people who saw themselves as Greeks and in settlements where non-Greek identities were stressed. ${ }^{82}$ Though the patterns of the street plans and the layouts of the houses may differ considerably, the construction

\footnotetext{
78 Barra Bagnasco 1989.

79 Giardino 1996.

80 Barra Bagnasco 1996, 50.
}

81 Barra Bagnasco 1990, 61.

82 Russo Tagliente 1992 and 1996. 


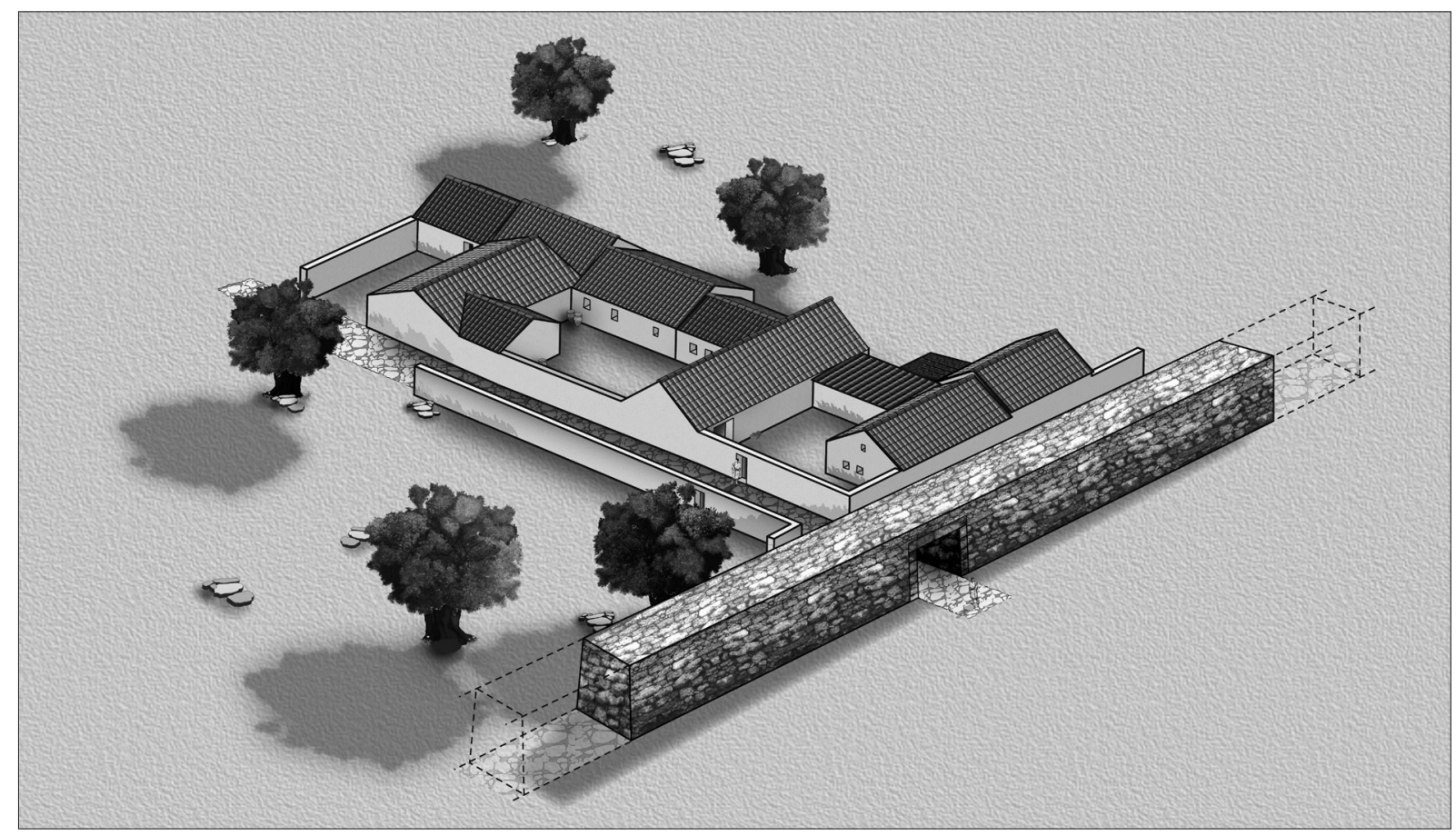

Fig. 6.19. Reconstruction of the excavated part of the northern quarter of Muro Tenente, south Apulia, early 3rd century BC.

techniques used for the houses show little variation. The construction of the houses of Herakleia, for instance, is relatively simple. The foundations and lower part of the wall (height c. 0.30 to 0.50 $\mathrm{m})$ consist of rounded stones taken from the nearby rivers. The upper part of the wall was made of mudbrick, while the tile-covered roof was sustained by large wooden beams. In areas that were rich in limestone (Salento, Bari district, upper Basilicata) square or irregular blocks of limestone replaced the cobblestones (fig. 6.17). The superstructure and the construction of the roof in these districts were invariably in very similar or identical techniques to those used at Herakleia: mudbrick, wooden beams sustaining terracotta rooftiles.

Whilst the courtyard house with a wide variety of subtypes was the dominant form of dwelling in the Greek towns of southeast Italy, ${ }^{83}$ the non-Greek settlements displayed an even wider variety of house types during the 4th and 3rd centuries BC. ${ }^{84}$ These range from simple two- or three-room houses (minimum c. 50-60 $\mathrm{m}^{2}$ ) to impressive elite residences covering hundreds of square meters. Both simple houses and large residences occur in different forms (fig. 6.18a-c). There was no widely accepted standard. As for the smallest houses, the most common form is the paratactic arrangement of two or three rooms (fig. 6.18b). Such dwellings occurred in all indigenous districts of southeast Italy. Mostly, however, the non-elite houses in large parts of Apulia and Basilicata were more comfortable and displayed a distinct likeness to the courtyard houses of Herakleia and other poleis on the Gulf of Taranto.

Large buildings usually interpreted as elite dwellings have been discovered in various places. The largest specimen hitherto reported was unearthed at the mountain top site of Serra di Vaglio in central Basilicata. ${ }^{85}$ It measured $33 \times 24 \mathrm{~m}\left(\mathrm{c} .800 \mathrm{~m}^{2}\right)$ and consisted of a large courtyard having a pastas

83 Barra Bagnasco 1990 and 1996.

85 Russo Tagliente 1996, 162 and Greco 1996, 257.

84 Russo Tagliente 1992 


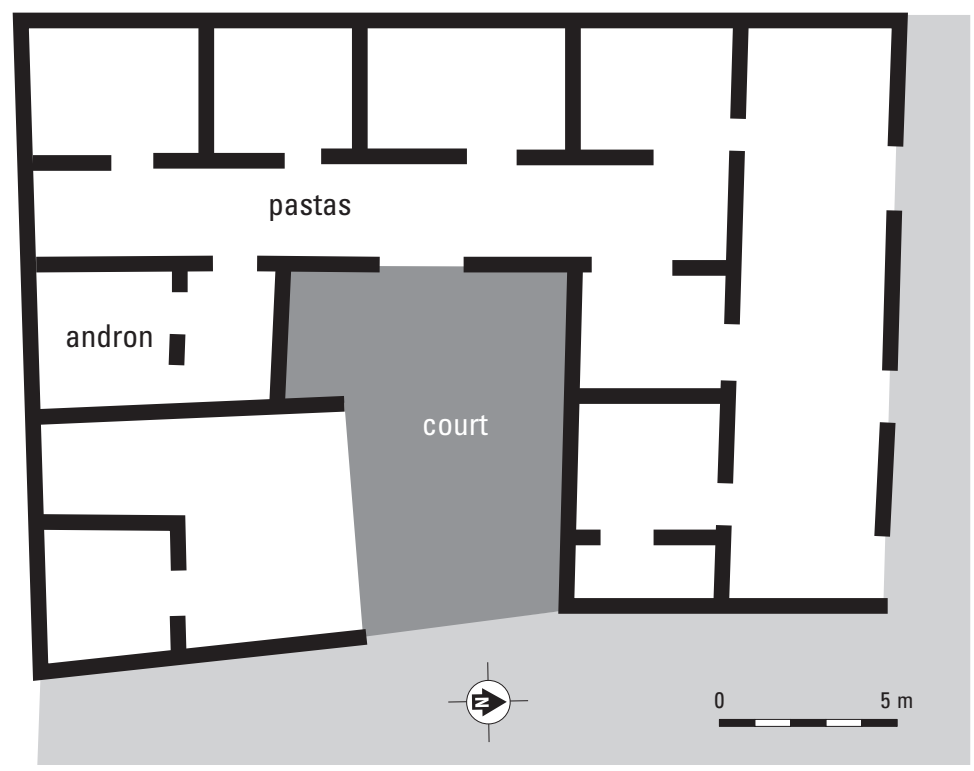

Fig. 6.20. Serra di Vaglio (central Basilicata): elite dwelling or elite dining hall, 4th century BC; after Russo Tagliente 1992.

(portico) on its western side (fig. 6.20). An almost equally large building covering an area of c. $750 \mathrm{~m}^{2}$ was excavated at the site of Vaste in the Salento district. ${ }^{86}$ The L-shaped Vaste building was situated in a dominant position on top of a $106 \mathrm{~m}$ high hill (the Vaste 'acropolis') and overlooked other parts of the settlement area of Vaste and the surrounding plain. It was, moreover, situated near a large court or square that was flanked by much smaller, but still fairly substantial dwellings (fig. 6.21). The complex was in close proximity to an impressive elite tomb (fig. 6.32). ${ }^{87}$ The elite of Roccagloriosa in western Lucania was probably slightly less well off. They lived on a wide street, and had to content themselves with only $450 \mathrm{~m}^{2}$. The central area in their house was a large porticoed courtyard with a small shrine. Rooms flanked two sides of the court (fig. 6.7). In these and other comparable elite residences banqueting rooms have been recognized.$^{88}$ This suggests that such rooms were a standard component in such large 'elite dwellings' of southeast Italy.

There is yet another aspect that recurs in many of these large, sometimes almost palatial buildings of native southeast Italy. Each of them has supplied evidence for ritual. The traces left by such activities may vary considerably. They consisted, for instance, of votive offerings, deposits containing only one species of animal and altars or hearths. This being the case, one may suggest that at least some of these large and complex buildings (especially the very large specimens at Serra di Vaglio and Vaste) were not (on not exclusively) the residences of elite families, but buildings in which the local or regional elite convened. They may have been places where the local or regional leaders made deals and took decisions, feasted and banqueted and performed specific rituals in order to confirm and strengthen their bonds under the protection of a divine spirit. These buildings may well have been the successors to the late 6 th and 5 th-century banqueting halls discussed in chapter 5 and may have been the places where the leaders of the dominant lineages of the local clans or regional tribes gathered.

86 D’Andria 1996.

87 The so-called Tomba delle Cariatidi, for instance, was only some 50 meters from the square; for this tomb, see D’Andria 1988, figs. 707-708.
88 These are often indicated as the andron in books and articles on pre-Roman architecture in southeast Italy (cf. Russo Tagliente 1992). 


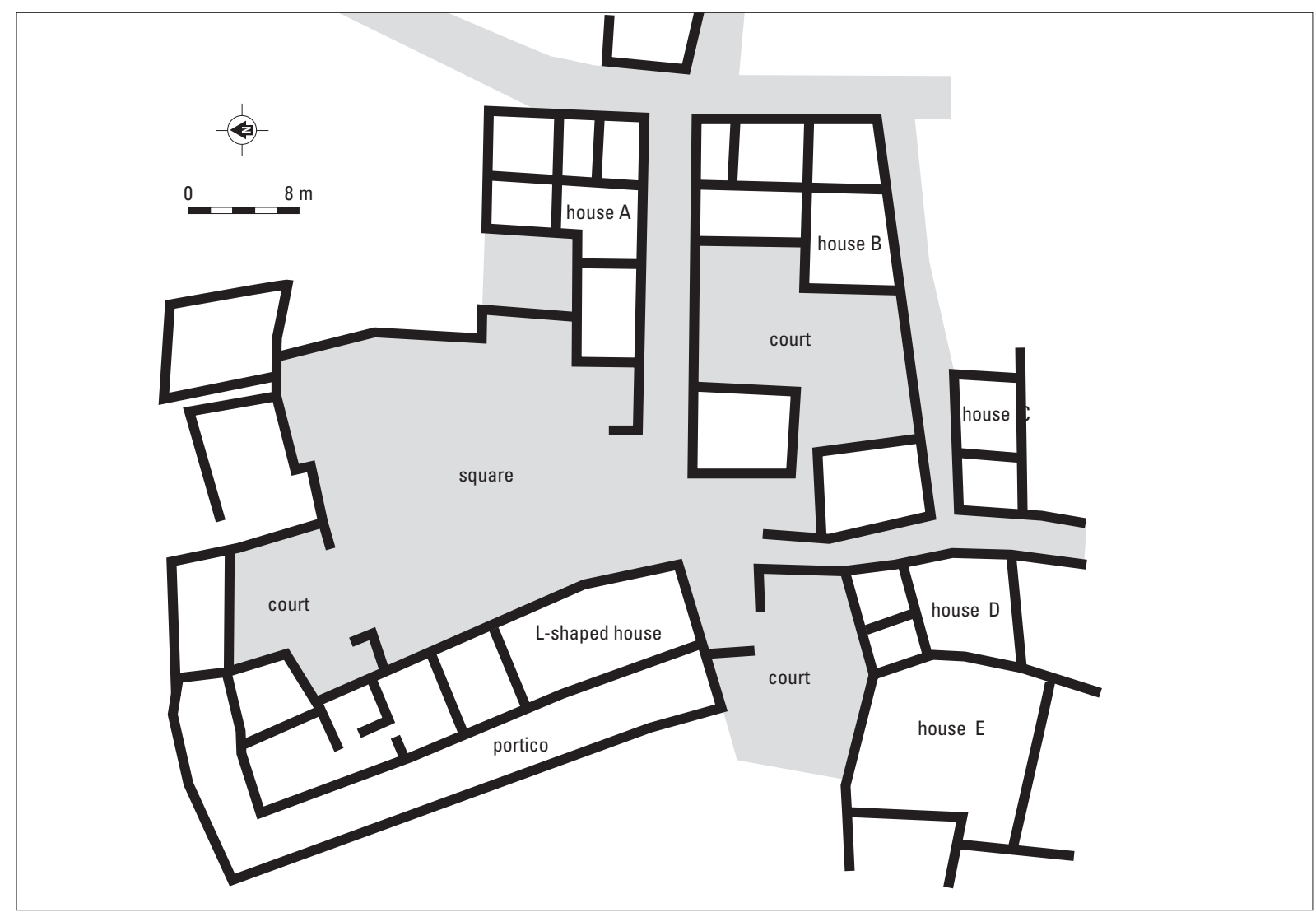

Fig. 6.21. Vaste (Salento district, south Apulia): central open area with L-shaped building and houses; late 4th and early 3rd centuries BC; after D’Andria 1996, 428.

Rural architecture in southeast Italy did not indulge in luxuries in the 4th and 3rd centuries BC. The farms were utilitarian buildings. These rural buildings display less variety than the architecture in the more or less urban centres of the region under discussion. Two different types of farmstead can be found in southeast Italy. The 4th-century farmsteads in the territories of the Greek states were often basically courtyard houses: they had rooms grouped around a court and did not differ from the farmhouses built in these areas during the later 6th and 5th centuries (fig. 6.22b). The farmsteads in the native countryside were decidedly different. They consisted of a series of three or four rooms giving onto a fenced courtyard (fig. 6.23).These simple, indigenous farms were probably inspired by the most simple house form found in the contemporary settlements (see fig. 6.18b). The construction technique of all the 4th-3rd-century farmhouses was identical to that of the dwellings in the larger settlements. The foundations and the lower part of the walls were made of stone (river stones, limestone), the upper part of the wall was made of mudbrick, while the thatched roof consisted of wooden beams covered by terracotta tiles.

Between the middle of the 4th and the middle of the 3rd century BC southeast Italy urbanized in many ways. We have seen that the first settlements with a more or less urban character came into being in the 6th century BC. By about 300 BC there were dozens of settlements having fortifications and substantial agglomerations of houses. Public buildings (theatres, stoas, temples), however, were exclusively found in the poleis. These developments led to a clear separation between habitation areas on the one hand and fields and wild nature on the other hand. But urbanization also affected the countryside. Whilst the creation of an inhabited countryside in southeast Italy can definitely be ascribed to the 

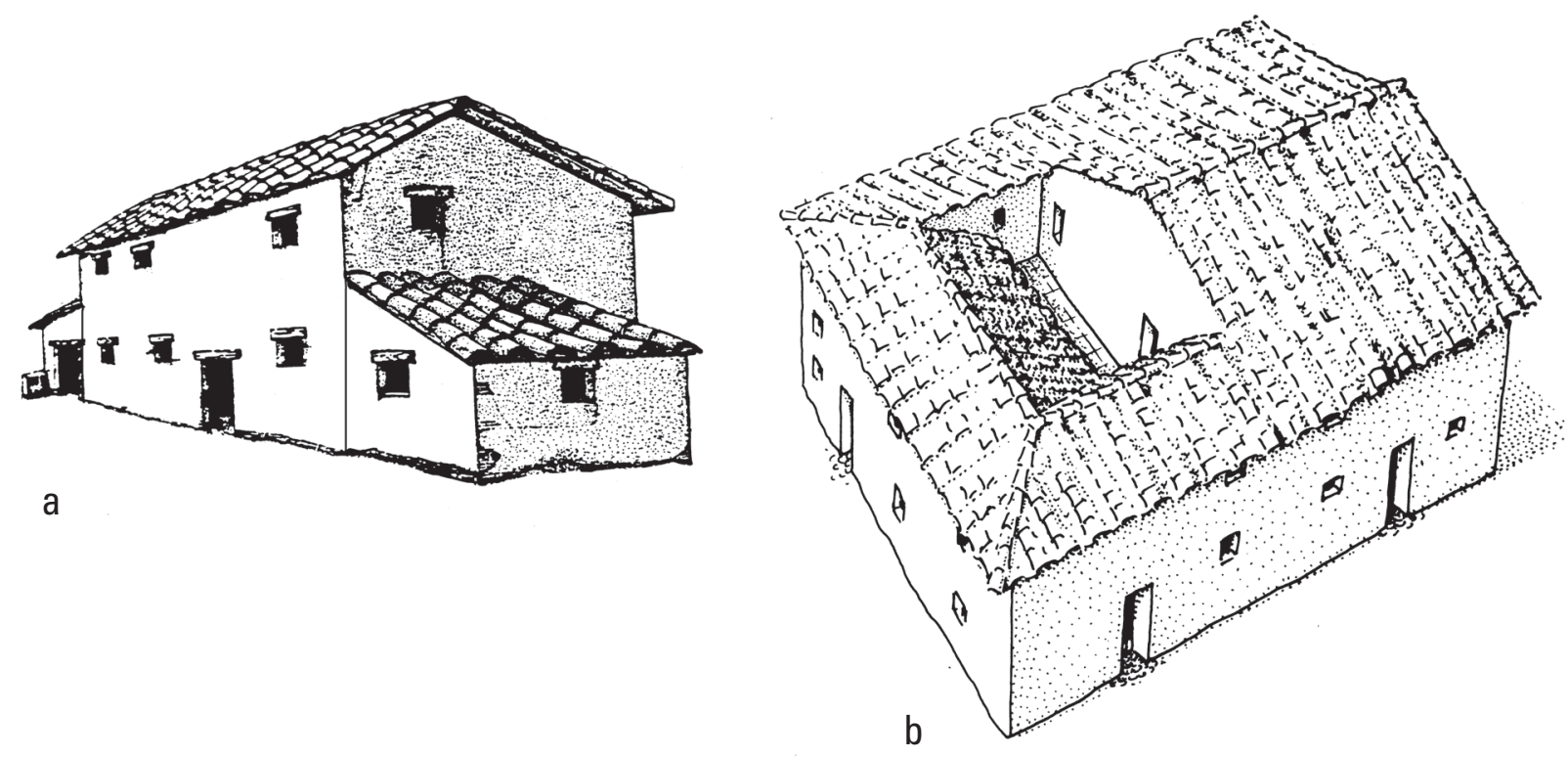

Fig. 6.22. Farmhouses in the territory of Metapontion, 4th-3rd century BC: a with paratactic rooms (Pizzica Pantanello); b courtyard type (fattoria Stefan); adapted from Carter 1980 and 1990.

Greek polities (6th century BC), similar town-countryside systems came into being in the territories of the Lucanian, Daunian and Messapian tribes in the late 4th century. These changes resulted in a hierachization of the settlement patterns in southeast Italy.

\subsection{MORTAL A N D I M MORTALS.}

The profound changes in the world of the living which have been discussed in the preceding section of this chapter were echoed by the world of the deceased. Both the increased prosperity and the strong demographic growth were reflected in the burials. This observation holds for both the Greek towns and the non-Greek areas of southeast Italy. Whilst the various local elites indulged in emulative and ostentatious display in both the burial gifts and the conspicuous character of their tombs, thousands of 'moderately rich' 4th- and 3rd-century tombs testify to the presence of large groups of prosperous people living in the area under discussion. This probably substantial part of the population was now allowed, or could now afford to be buried with objects in quantities and of a quality that were reserved for the most prosperous and influential people of the settlement in the archaic-classical period.

The largest and most complete sample of tombs has been found at Greek Taras, now Taranto. ${ }^{89}$ All in all, approximately 11.700 tombs have been collected in a database up to this moment. The vast majority of these appear to belong to the Hellenistic period. ${ }^{90}$ Here the necropolis of Taras will be used in order to sketch a picture of the funerary spheres in the Greek polities of southeast Italy. This image is necessarily biased, because Taras was undoubtedly the wealthiest Greek town in the area under discussion. Its $\tau \rho v \varphi \eta \dot{~(o p u l e n c e) ~ w a s ~ p r o v e r b i a l ~ i n ~ t h e ~ a n c i e n t ~ w o r l d . ~}$

The elite graves of wealthy Taras were marked by highly conspicuous funerary aedicula displaying elaborate sculptured decoration (fig. 6.24a). These shrines of wood and limestone are currently

89 See Cento anni di archeologia, passim.

90 Lippolis 1994b; Graepler 1997, 30. 


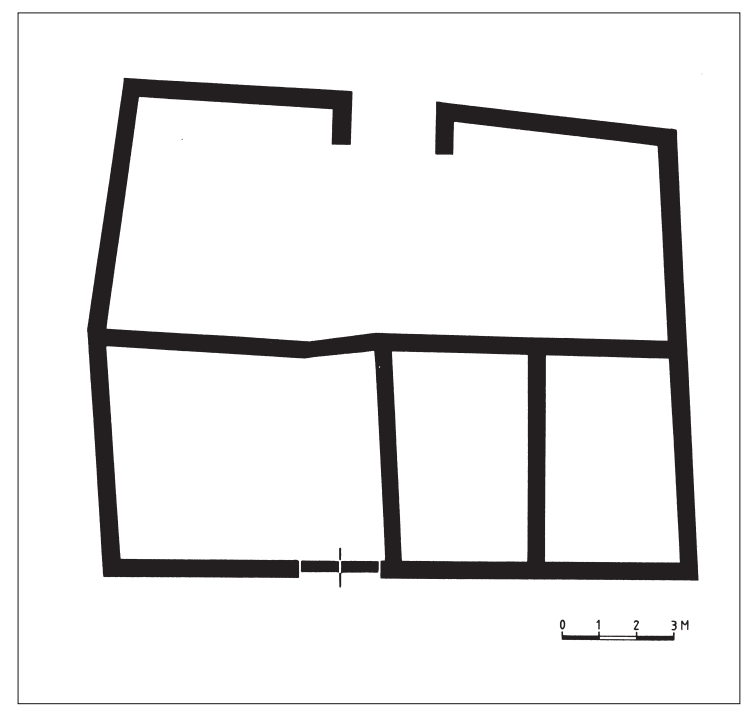

Fig. 6.23. Groundplan of farmhouse near Banzi (northeastern Basilicata). After Yntema 1993a.

referred to as naiskoi. They stood on top of substantial chamber tombs. These had sometimes painted walls and functioned as family vaults that were used for several generations. ${ }^{91}$ The remains of these highly conspicuous monuments crowning the subterranean burial chambers consist of architectural and sculptural fragments (fig. 6.24b-c). These have been discussed by various authors. ${ }^{92}$ The naiskoi and other types of grave markers are also depicted on many Apulian Red-Figured kraters (fig. 6.24). These were produced at Taras in large numbers for funerary purposes only. ${ }^{93}$

Alongside these spectacular elite tombs there was a wide variety of other burial forms at Taras. These ranged from simple trenches excavated in the soil or cut into the rock to sarcophagus tombs and graves consisting of large limestone slabs. The deceased were almost invariably inhumed. ${ }^{94}$ The Taras burial grounds were situated outside the habitation areas, but within the area enclosed by the city walls. They were truly cities of the dead (fig. 6.25). The burials flanked major roads and were arranged in family clusters that covered three to four generations. ${ }^{95}$ Within these clusters the graves were arranged with a regularity that matched the structure of the habitation areas and the layout of the settlement as a whole.

The artefactual contents of the Taras tombs varied according to the age, status, sex and wealth of the deceased. Small children were buried with a feeder. The standard equipment in the tombs of adults was the pouring vessel (mostly an oinochoe) and the drinking vessel (skyphoi, kantharoi etc.). To these two pots gender-specific objects could be added: e.g. bronze strigils for men and bronze mirrors for women. The same burial gifts were found in the elite tombs, but in addition to these they contained golden objects such as funerary crowns, elaborate ear rings, finger rings with gems, necklaces and bracelets (fig. 6.26). ${ }^{96}$ The most spectacular object from the Taras graves is perhaps a pair of nutcrackers in the shape of two hands, made of partly gilded bronze (fig. 6.26).

If the above assumption is correct that the burial gifts at 4th- and 3rd-century Taras were indeed both gender and status related, men and women of the same social group were buried with comparable rites and objects of comparable value. Cups and jugs currently associated with wine were standard elements among the grave goods. Gold and silver ornaments were status indicators for the local elite. The same may hold good for the alabastra made of fine alabaster. The vast majority of Tarentines, however, were buried with less precious objects such as pottery, terracotta statuettes and small items made of bronze and iron. But the general impression gained from the Taras burial sites is that the town defi-

91 Lippolis 2003.

92 For instance, Carter 1975; Lippolis 1994c.

93 Lohmann 1979.

94 Cremations are found among the earliest burials of Taras of the 7 th century BC. From the 6th century onward inhumation was the dominant burial ritual till within the Roman period. From the late 4th century $\mathrm{BC}$ onward, however, cremation reappears after an absence of more than 200 years, albeit very sparingly (D'Amicis 1994).

95 Lippolis 1994b, 57.

96 See Masiello 1994. A fairly complete presentation of these spectacular objects and the funerary context from which they derive can be found the exhibition catalogue Ori di Taranto, Milan, 1984; for a general overview, see Guzzo 1993. 


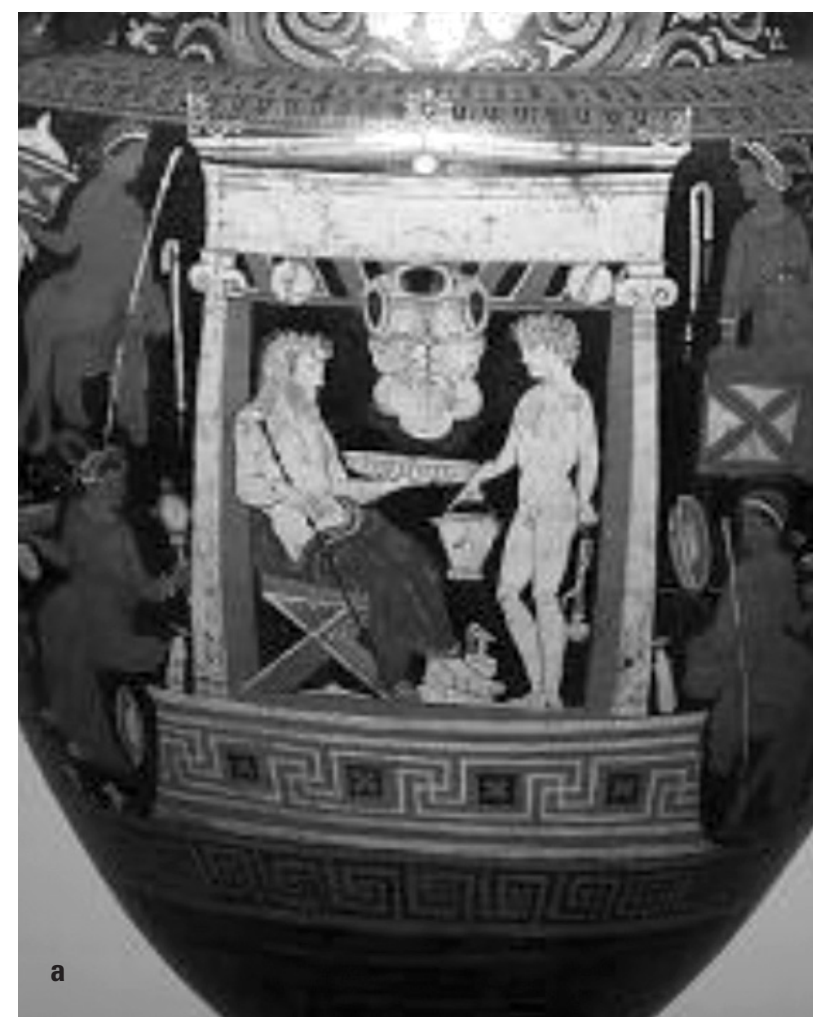

Fig. 6.24. Funerary monuments in 4th-century southeast Italy (a) Image of a Taras funerary monument on an Apulian Red-Figured krater (c. 330 BC); (b-c) two metopes of funerary monument (early 3rd century BC). Taranto, Museo Nazionale; courtesy Soprintendenza Taranto.

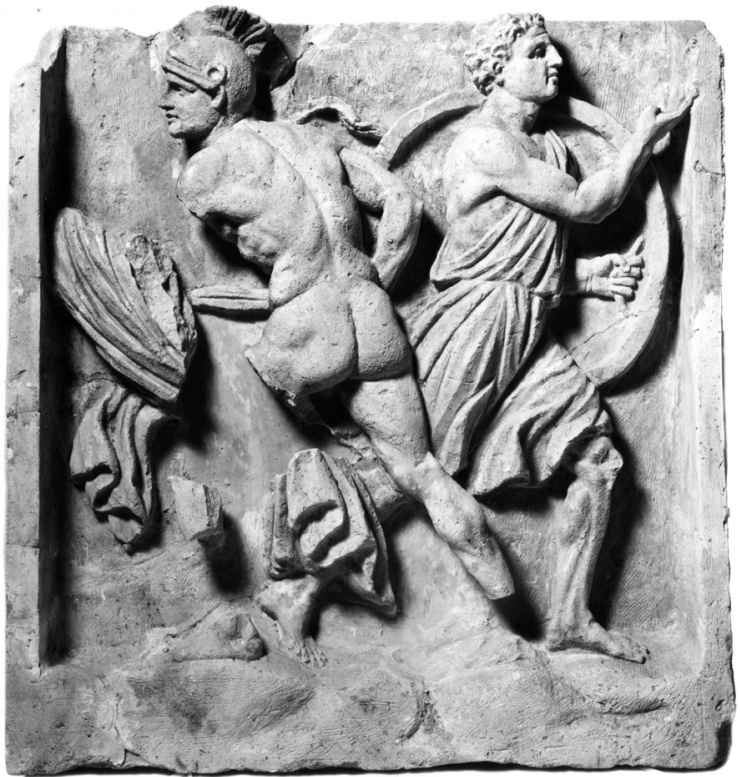

b

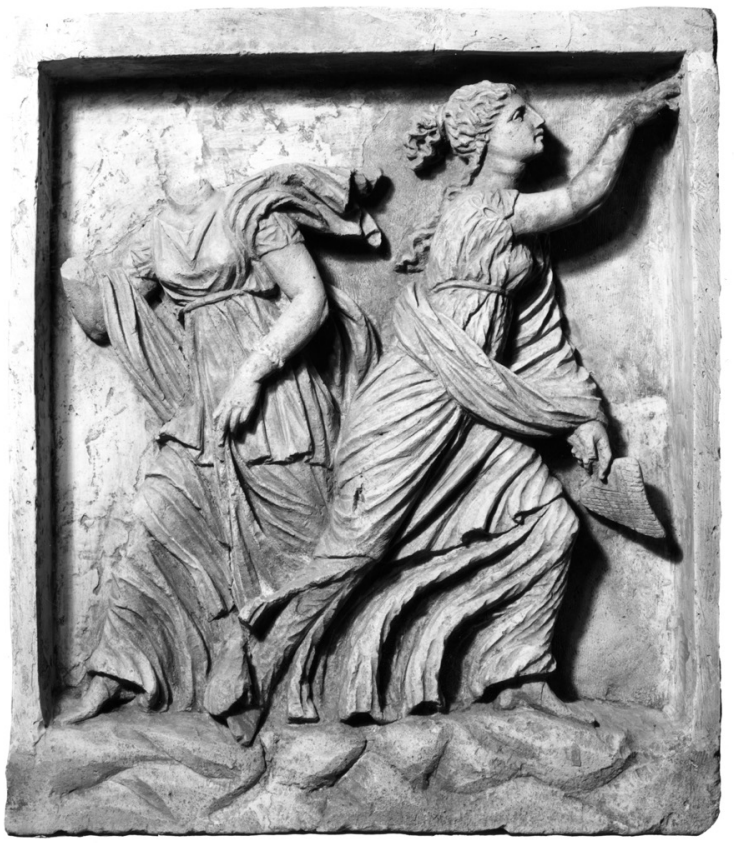

nitely had a limited group of elite families and a very large group of more or less prosperous families. Judging by the contents of the thousands of burials the distinctions between the various social groups in Taras were not sharply marked in the funerary sphere. ${ }^{97}$

Taras had intramural cemeteries. At both Metapontrion and Herakleia the necropoleis were situated outside the town walls. Most of these have not been subjected to systematic exploration or analysis of their contents. The general impression that emerges from the graves of these two towns is that ostentatious display of wealth was less pronounced here. At Metapontion and Herakleia there were probably no naiskoi with sculptured decoration, the chamber tombs were more modest and less numerous, whilst

97 The social aspects of the Taras cemeteries and the problematic use of material culture for this purpose have not yet been systematically analysed and explored (cf. Lippolis 1994a; Graepler 1997). 


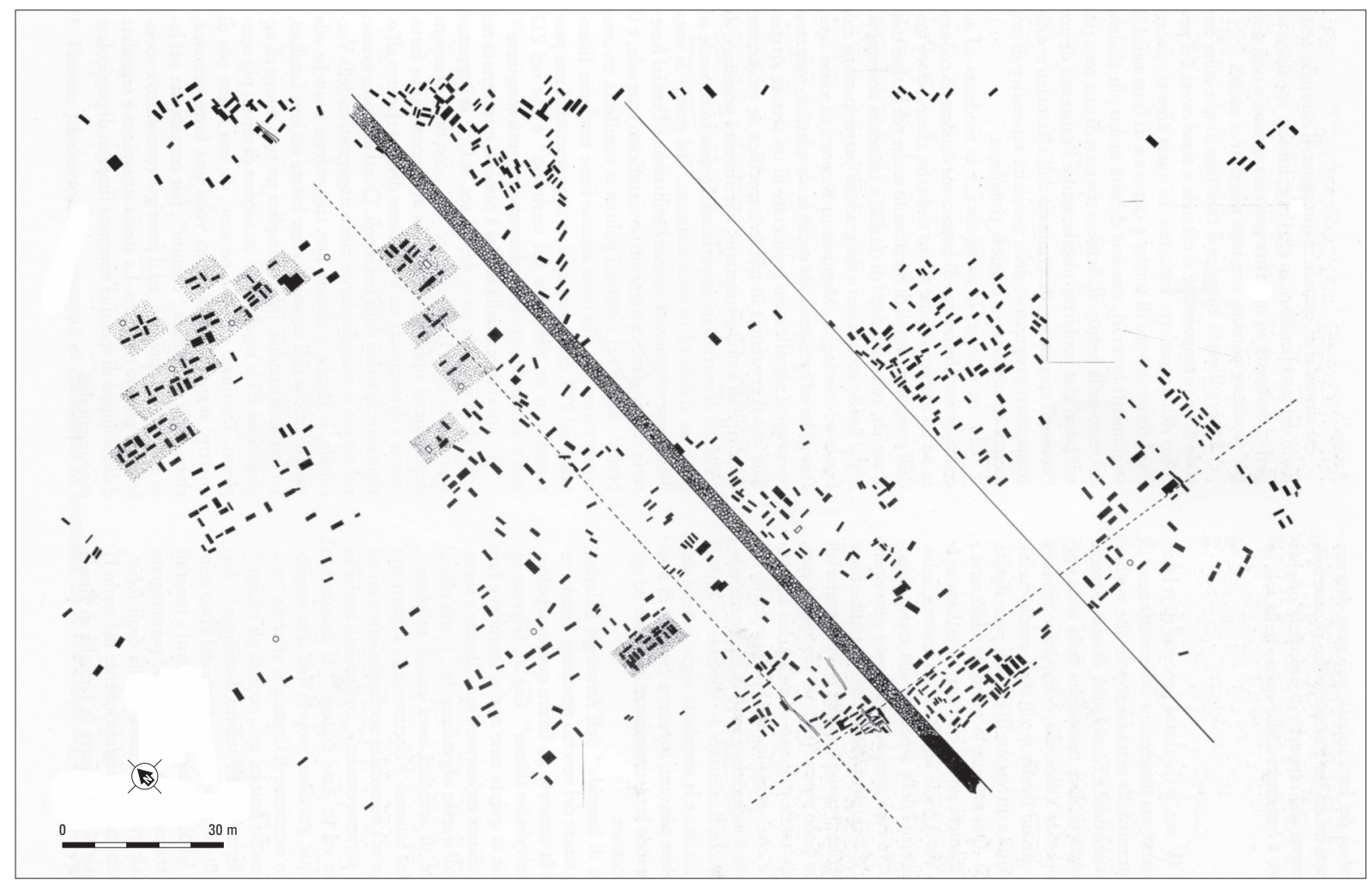

Fig. 6.25. Taras, burial ground with family plots, 4th-2nd century BC; after Lippolis 1994b, fig. 36.

most of the objects found in the graves were less spectacular than those in the Tarentine burials of the 4th and 3rd centuries BC. ${ }^{98}$ The most basic objects, however, are again a cup or drinking vessel and a pouring vessel.

Not every citizen of the Greek towns was buried in the necropoleis within (Taras) or slightly ouside (Metapontion, Herakleia) the city walls of the polis. The people who lived at the farmsteads in the territories of these Greek towns, were buried in rural graveyards. These were in use for between 50 and 300 years and varied in size from half a dozen to c. 250 graves. Those who were buried in these cemeteries in the chorrai, were not exclusively simple farmers. The social strata represented in the rural graveyards closely reflect those of the urban cemeteries: they show the presence of both elites and moderately prosperous families. There is ample proof of such rural cemeteries from the territory of Taras. The best (and largest) example of a completely excavated and well published rural necropolis is the graveyard of Pizzíca Pantanello in the territory of Metapontion. ${ }^{99}$ It contained some 300 tombs dating between the middle of the 6th and the middle of the 3rd century BC. The cemetery was situated near an important crossroads north/west of the town (fig. 5.8). Field surveys suggest that the people buried there were not the inhabitants of a village or hamlet nearby, but had probably lived at dispersed farmsteads in the area surrounding the necropolis.

98 For graves at Metapontion, see, for instance, Lo Porto 99 Carter 1998a. 1981 and 1988/89; for Herakleia, see Pianu 1990; for short summary of the Metapontion burial sites, see De Juliis 2001 . 


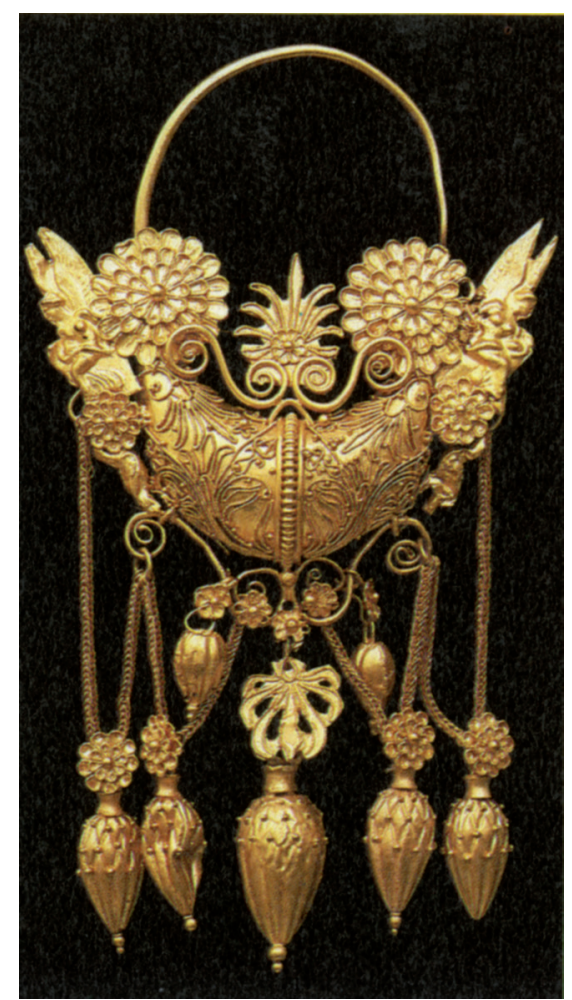

Fig. 6.26. Tarantine jewellery: a. Golden earring from Taras, height 9.9.cm; b. Golden earrings from Taras; length $4.2 \mathrm{~cm}$; c. Bronze nutcrackers in the shape of hands with gilded bracelet; from Rondinella (rural site close to Taras); length $16.4 \mathrm{~cm}$; late 4th-early 3rd century BC; courtesy Soprintendenza, Taranto.
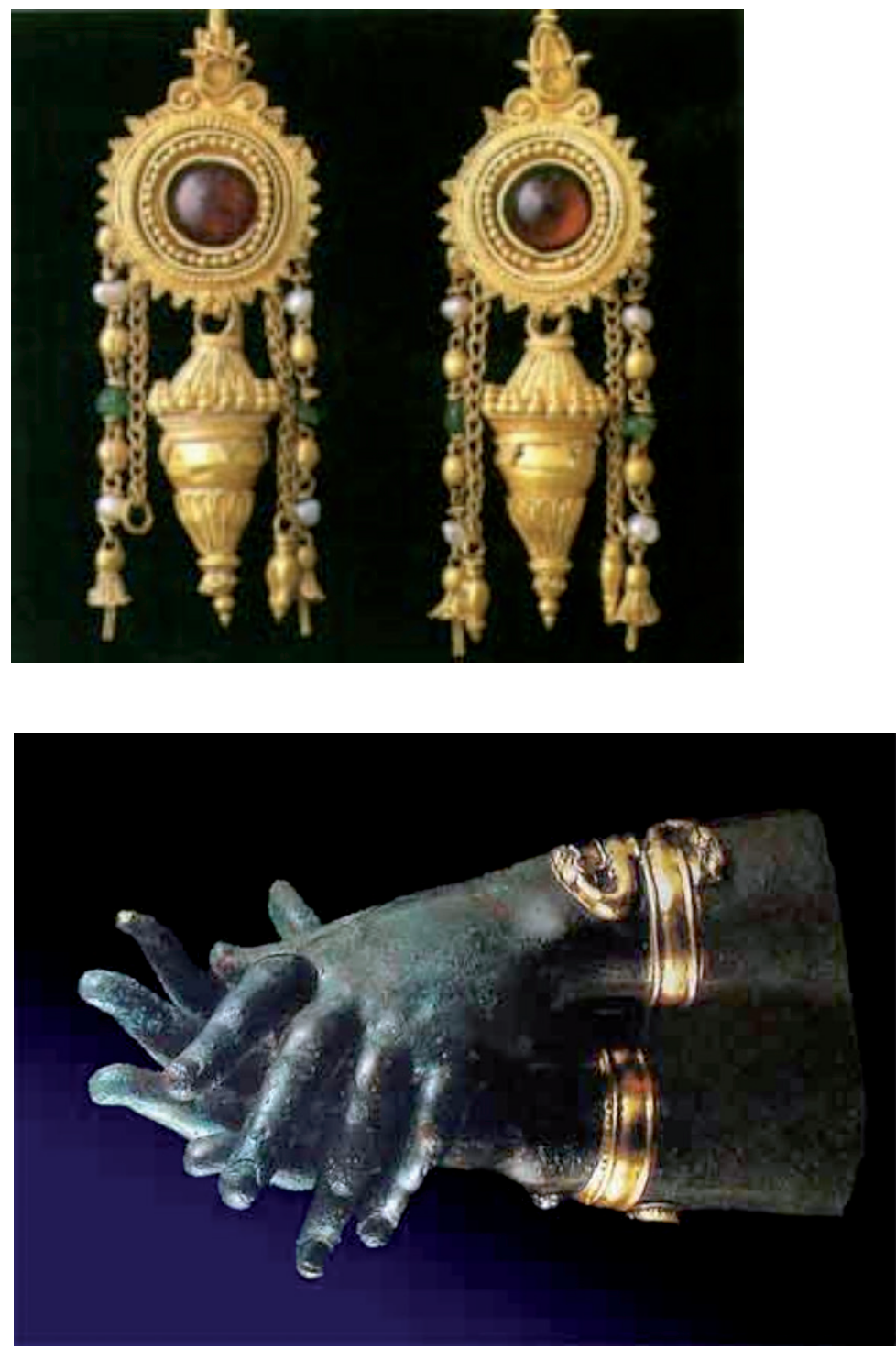

In the districts inhabited by the ancestors of the Lucanians of Basilicata, by the Peucetians of central Apulia and by the Daunians of northern Apulia formal burials were relatively common from the 8 th or early 7 th centuries onwards. The Messapians in southern Salento were slow in adopting this custom: it was not before the end of the 7th century that the first burials are found there. We have seen that during the 7th century BC the non-Greek graves differed from the Greek graves by the lavishness of burial gifts and observed that the Greeks soon lived up to the regional custom. In the 4th century BC grave goods in non-Greek burials continued to be plentiful (especially pottery). What is new is that from about the middle of the 4th century BC the quantity of tombs in the non-Greek areas of southeast Italy increased exponentially.

The increase was only partly caused by demographic growth. By the later 4th century a much larger group in the native societies was given a formal burial. A close inspection of the bones from a series of modest late 4th-/early 3rd-century graves from Muro Tenente (Brindisi) revealed that the deceased worked hard (physical labour), were well-fed and had a predominantly vegetarian diet. It consisted mainly of barley bread, gruels and porridges. Those who survived their first four or five critical years (infant mortality was high), had an average life expectancy of c. 30 years (women) to 40 years (men). Other data confirm that most people died at a relatively young age. The rural Pantanello necropolis 


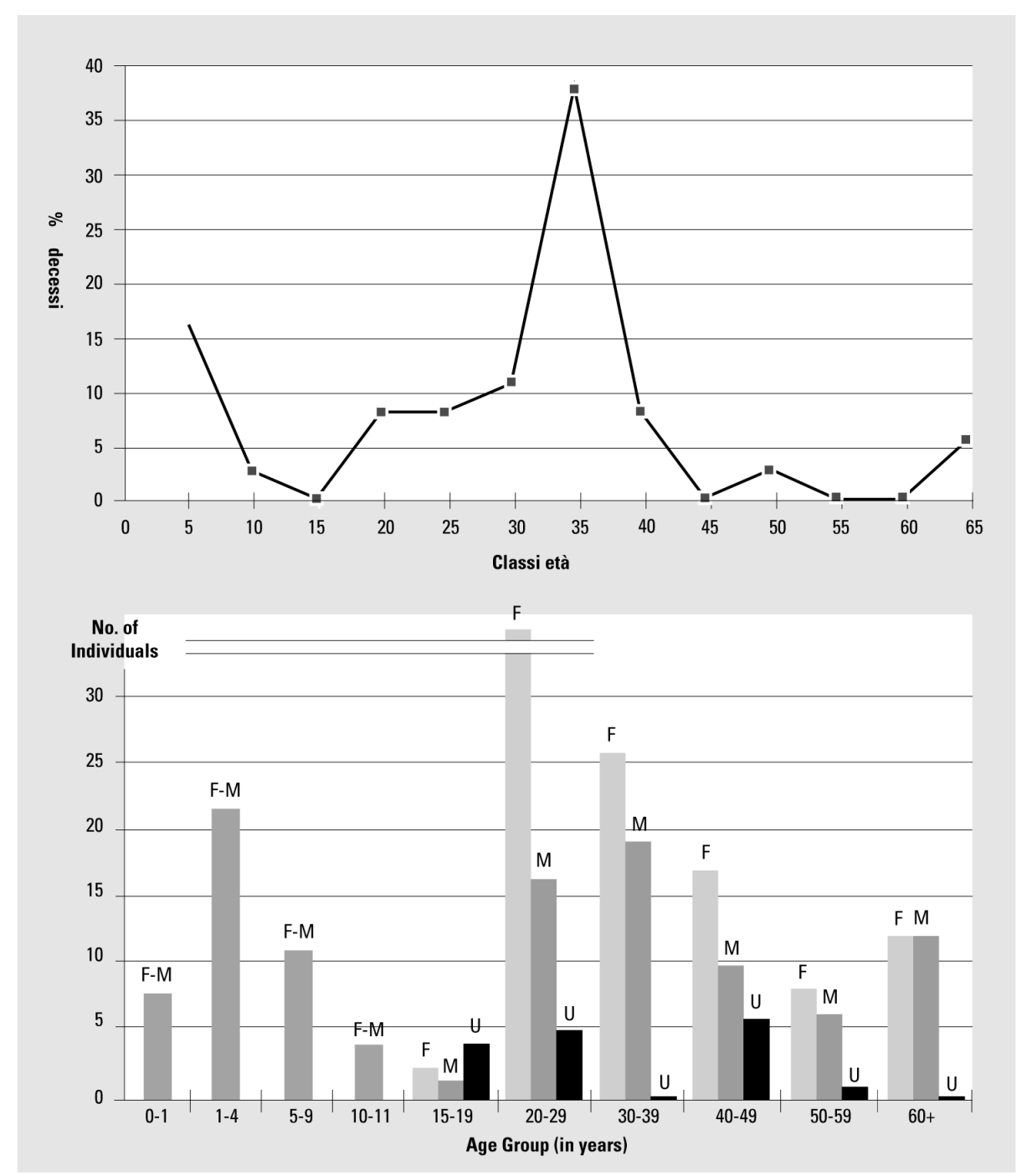

Fig. 6.27. Life expectancy at Pezza Petrosa (Brindisi), 4th-3rd century BC, and at Pizzica Pantanello (Metaponto), 6th-3rd century BC; after Maruggi 1992 and Carter 1980.

(Metapontion), the burial site of the village of Pezza Petrosa (Brindisi area) and the graves found at Rutigliano-Purgatorio (central-Apulia) suggest that most people in pre-Roman southeast Italy died before they turned forty (fig. 6.27).

At first sight Greek and non-Greek burials in 4th-century southeast Italy seem to have much in common. The native cemeteries of the early Hellenistic period, however, display only a limited number of similarities with the burial grounds in the territories of the Greek poleis. In the native burial grounds the deceased were buried in trenches in the earth or in the rock (Italian: tomba a fossa), in sarcophagi, in cist graves consisting of large limestone slabs (Italian: tomba a lastroni) or in subterranean chamber tombs (hypogaea). These same types of graves are encountered in graveyards of the Greek towns of southeast Italy. The differences regard mainly the spatial organization and the grave goods. Native graves, for instance, rarely clustered into larger necropoleis. They usually occur in small groups of three to twenty burials. Whilst in Lucania these were probably slightly outside the habitation areas, these burials were dispersed over large parts of the settlement areas in the Apulian districts. In the Messapic speaking world of Apulia, therefore, there was no strict spatial separation between the world of the living and the world of the dead. The custom of depositing the deceased in burial plots close to the habitation nucleus in which they had lived, persisted here to within the 3rd century BC (fig. 


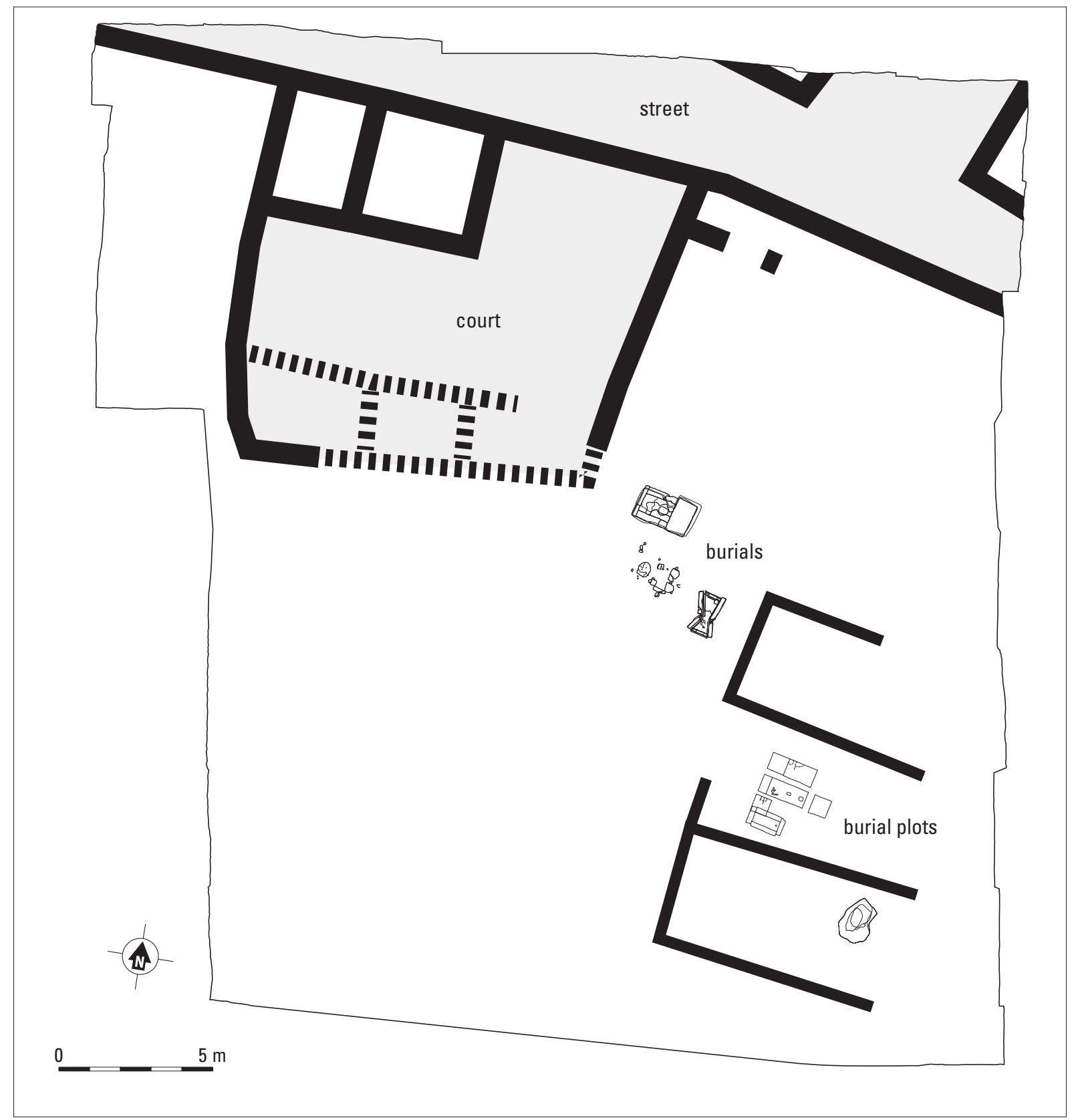

Fig. 6.28. Muro Tenente (Brindisi district, south Apulia). Central area of the walled settlement with proximity of elite dwellings and elite burials (c. 325-250 BC). Excavations VU University Amsterdam.

6.28). The ancestors lay buried in that particular part or territory within the settlement area where their descendents continued to live. This close association between the dead and the living is found over large parts of indigenous southeast Italy. It may suggest that the ancestors continued to play an important role in daily life and in some way continued to be an active element of their clan group.

Other features that distinguished the non-Greek tombs from the Greek graves of Hellenistic southeast Italy were the grave goods. A characteristic shared by all non-Greek districts is that the male elite graves often contain armour and weapons. The martial qualities of local chieftains which were important during the 6 th and 5 th centuries $\mathrm{BC}$, continued to be stressed during the later 4th and early 3rd centuries BC. Among the objects that heralded martiality, were helmets, spurs and javelins (fig. 

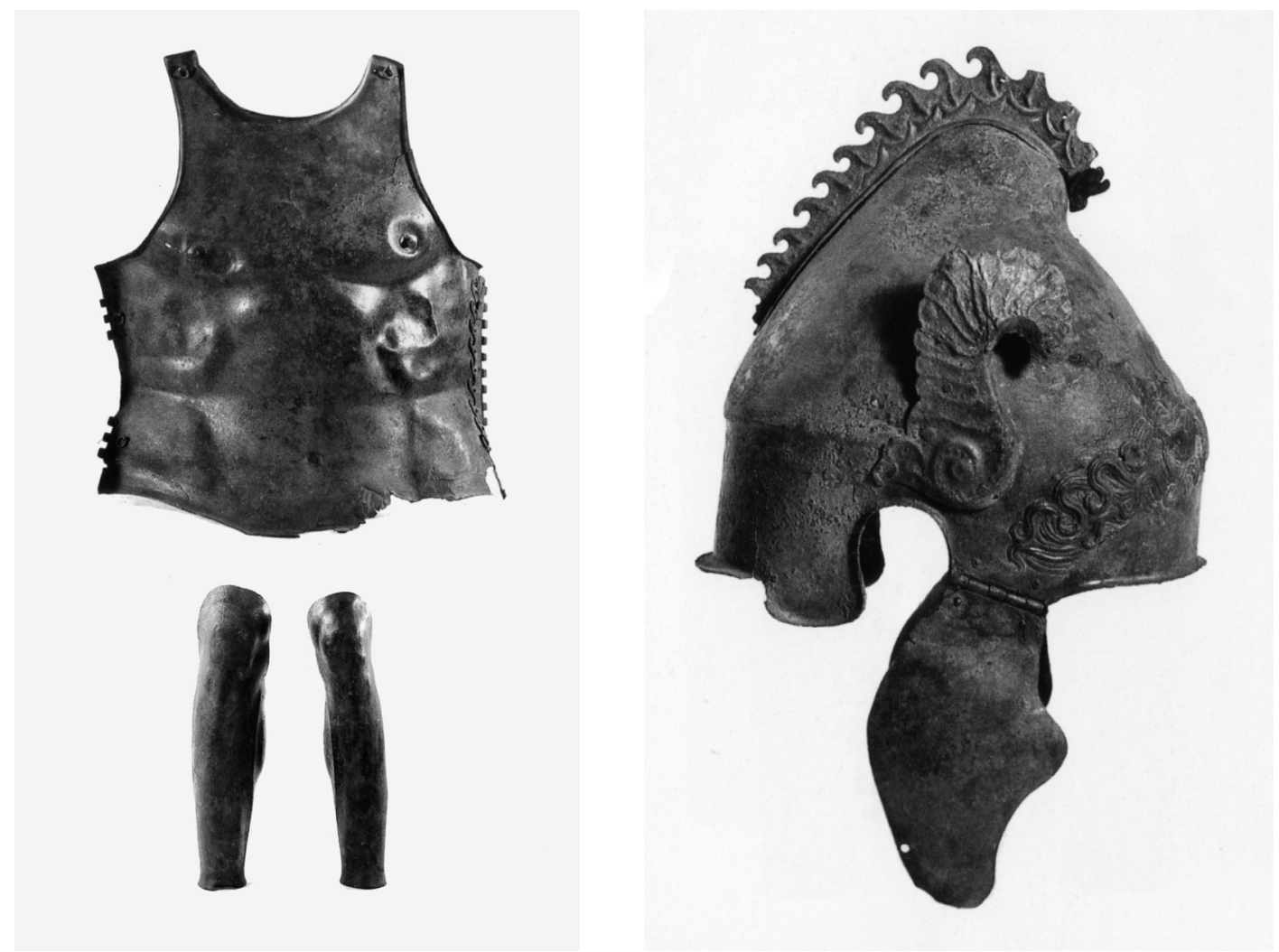

Fig. 6.29. Conversano (Bari), body armour from tomb 10 (4th century BC). Courtesy Bari Museum.

6.29). ${ }^{100}$ In a few cases the elaborate 'anatomical' cuirasses were found in chieftain's graves. ${ }^{101}$ These special objects are also depicted in the tomb paintings of 'Lucanian' Paestum. ${ }^{102}$

There was, however, no typical 'native' burial custom that could be encountered in most parts of southeast Italy. There were vast differences between the 4th- and 3rd-century burials of the various non-Greek districts. First and foremost are the differences between the north-Apulian Ofanto and Tavoliere districts and the remaining parts of southeast Italy. We have seen in the preceding section that the settlements of these two northerly so-called 'Daunian' districts retained their highly dispersed basically Iron-Age character during the early Hellenistic period. In the funerary sphere, Iron Age features were equally retained. This observation holds especially good for the objects that accompanied the deceased in his or her grave. Handmade, matt-painted pots in traditional Daunian styles continued to be popular as grave goods. Whilst these were replaced by wheelmade wares in the Tavoliere district between 375 and $325 \mathrm{BC}$, the Ofanto area focusing on the large site of Canosa adhered to funerary wares with various Iron-Age features to within the early 2nd century BC. ${ }^{103}$ Another traditional feature was the sometimes extreme lavishness of grave goods. Tombs containing precious metal objects and well over a hundred pots (many of which are practically identical) are by no means exceptional.

100 For the role of javelins in elite representation, see Small 2000.

101 For anatomical cuirasses, see for instance D'Andria 1988, figs. 714-716 (from Conversano, central Apulia); De Juliis 1988b, 631, fig. 19 (from Canosa, north
Apulia); Bottini 1989 (from southern Basilicata); D’Agostino 1989, 210-211, figs. 165-169 (from Santa Maria del Cedro, northern Calabria).

102 Pontrandolfo Greco / Rouveret 1992. 


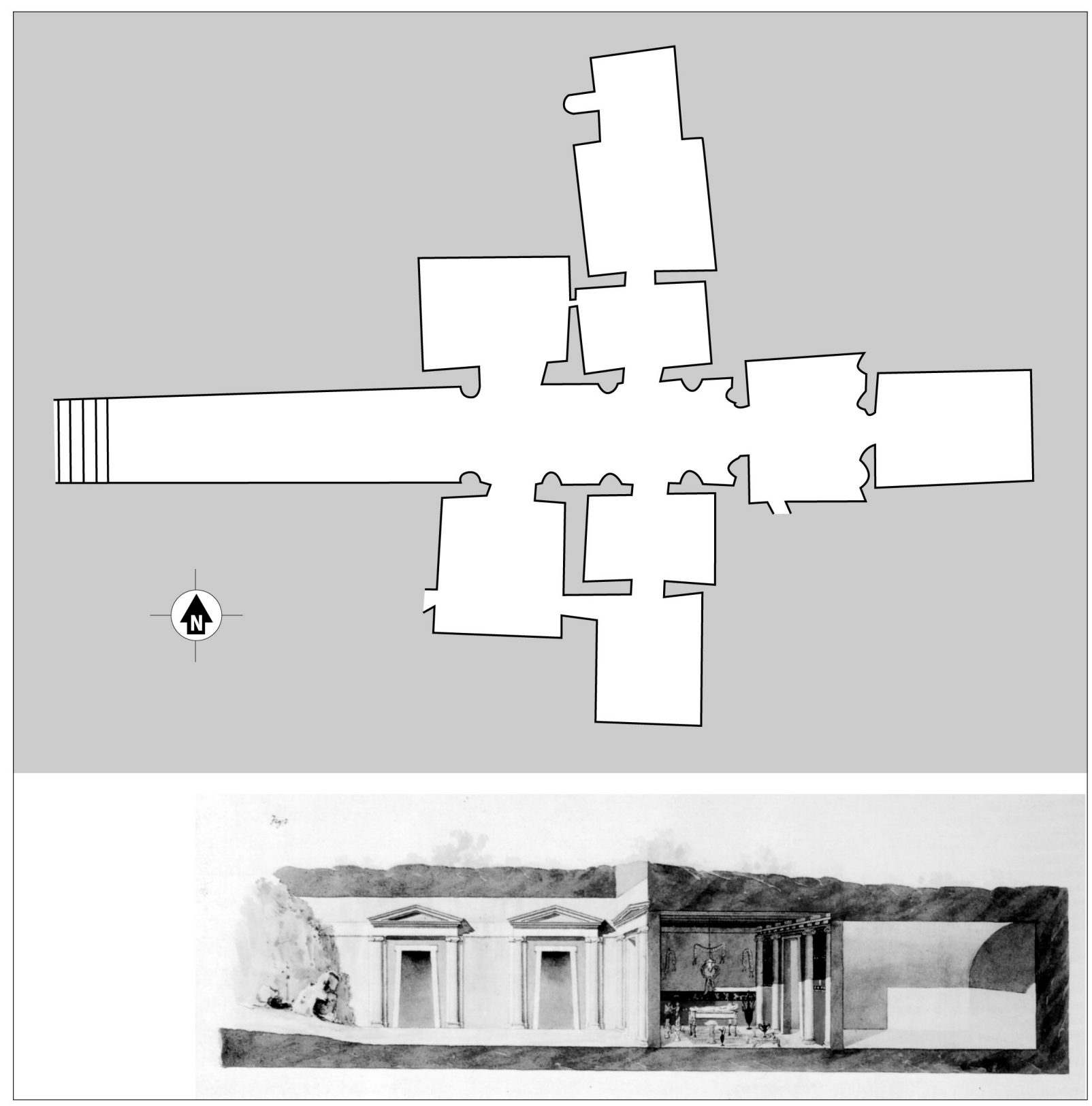

Fig, 6.30. Canosa, north Apulia: the Lagrasta I hypogaeum: plan and watercolour by Bonucci (1854).

The Daunian tribes were not purely traditionalists. They were also susceptible to innovation in the funerary sphere. This is not really evident in the tombs of most north-Apulians, which continued to be fossa graves. For elite tombs, however, they adopted the Greek elite custom of burying the dead in subterranean chamber tombs. ${ }^{104}$ Canosa, for instance, had more than a dozen of these from the late 4th century onward. ${ }^{105}$ Here they were hewn in the calcareous base rock of the site with dimensions surpassing by far those of the graves at Taras and Metapontion. The Lagrasta I hypogeum was the most elaborate of these Daunian elite graves. It had a dromos descending towards nine rooms (each approximately $4 \times 3 \mathrm{~m}$ ) which were decorated with Doric and Ionic half-colums. The adjoining Lagrasta II

103 The most recent Canosan funerary wares with various traditional features are the so-called Listata wares (for short survey, see Yntema 1990, 272-286)

\footnotetext{
104 Lamboley 1982.

105 Cassano et al. 1992, 145-148.
} 


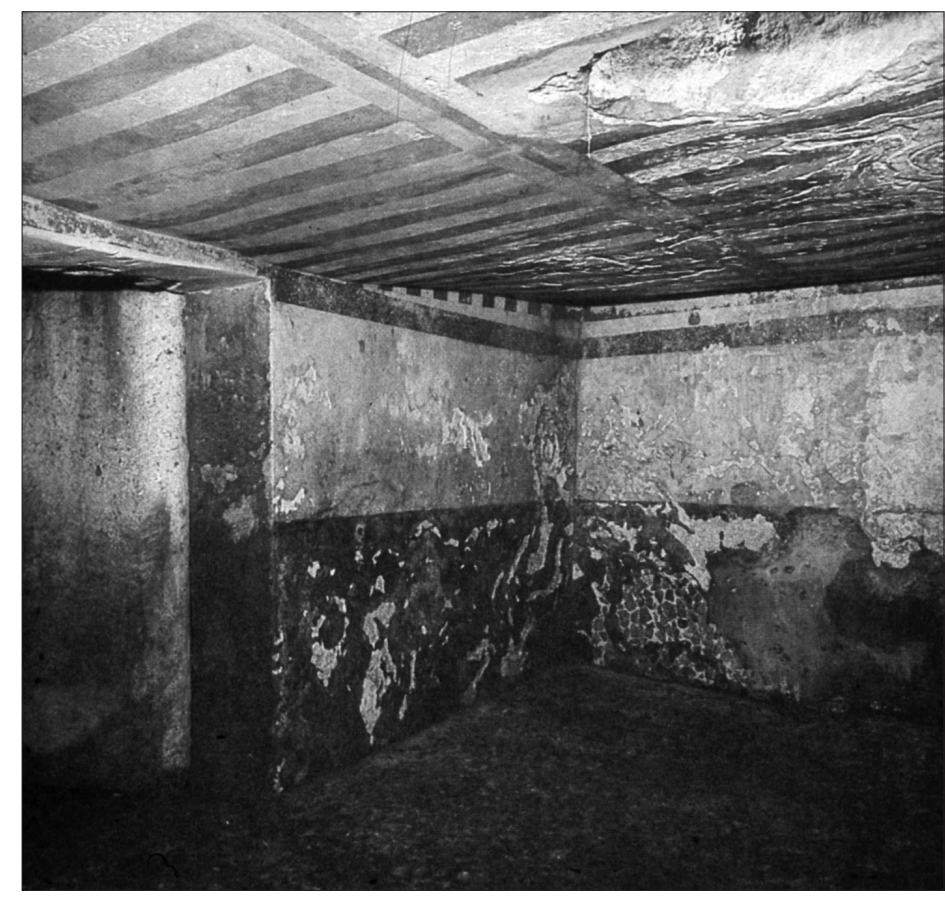

Fig. 6.31. Gnathia (Salento district) Ipogeo delle Melograne (Hypogaeum of the Pomegrenades); 4th-3rd century BC (courtesy Soprintendenza Taranto).

hypogaeum had a temple façade serving as a conspicuous marker of the subterranean complex above ground level (fig. 6.30). The Canosan hypogaea ooze opulence and power. They contained, for instance, panoplies (even a Celtic helmet), bronze belts, horse bits, javelins, jewellery, terracotta statues and an amazing host of pots of many kinds. ${ }^{106} \mathrm{~A}$ comparable opulence in the funerary sphere existed probably at the site of Arpi which was the most important settlement in the more northern Tavoliere district.

Here much evidence has been destroyed as a result of large scale tomb robbery. ${ }^{107}$

Canosa (and probably more northern Arpi) had more than a dozen of these chamber tombs. ${ }^{108}$ Most of these functioned contemporaneously and they were nearly all used for some two hundred years, starting from about 340-320 BC. ${ }^{109}$ Therefore, they contained entire dynasties of wealthy Canosans. These data, moreover, suggest that the same opulent elite families of Canosa managed to stay in power for several generations. Together these families may well have made up a closely knit local aristocracy, a kind of elite caste that excluded other groups of the local society from the means to gain wealth and influence. The marked traditionalism in the Canosan funerary culture, moreover, may well be read as a sign that strict adherence to age-old local customs was a vital element in the local socio-political system. Whoever managed to display his or her wealth and advertise a long and noble pedigree (be it real or invented), could be sure of his place in the local timocracy. ${ }^{110}$

Chamber tombs were equally popular with the elites of the south-Apulian Salento district. ${ }^{111}$ This was according to ancient Greek and Roman authors, the area of the Messapians. The appearance of such special elite graves in Salento was contemporary to that in northern Apulia. The earliest Salento specimens date to late 4 th century BC. These chamber tombs were not so overwhelmingly ostentatious as

106 See Oliver 1968, Cassano et al. 1992; Corrente 2003. The pottery classes currently found in the Canosan hypogaea are late Apulian red-figured, Gnathia wares, traditional matt-painted wares in the local style (Canosan Listata wares), gilded pottery and the typically Canosan wares with polychrome and plastic decoration (see this chapter, section 4).

107 For elite tombs at the site of Arpi, see Mazzei 1995.

108 One or two elite chamber tombs also existed in other settlements which by the late 4th century may well have been dependencies of Canosa such as Ascoli
Satriano and Salapia. The elite burials of these sites published hitherto are relatively recent and date to the late 3rd or early 2 nd centuries BC (e.g. Tinè Bertocchi 1985, 209-219; Mazzei 1991).

109 An inscription in one of the Lagrasta chamber tombs of Canosa indicates that someone was buried there as late as 67 BC (see Oliver 1968, 22-23).

110 Livy (XXII, 50, 11) suggests that there were also wealthy and powerful women at Canosa during the 3rd century BC.

111 Lamboley 1982. 

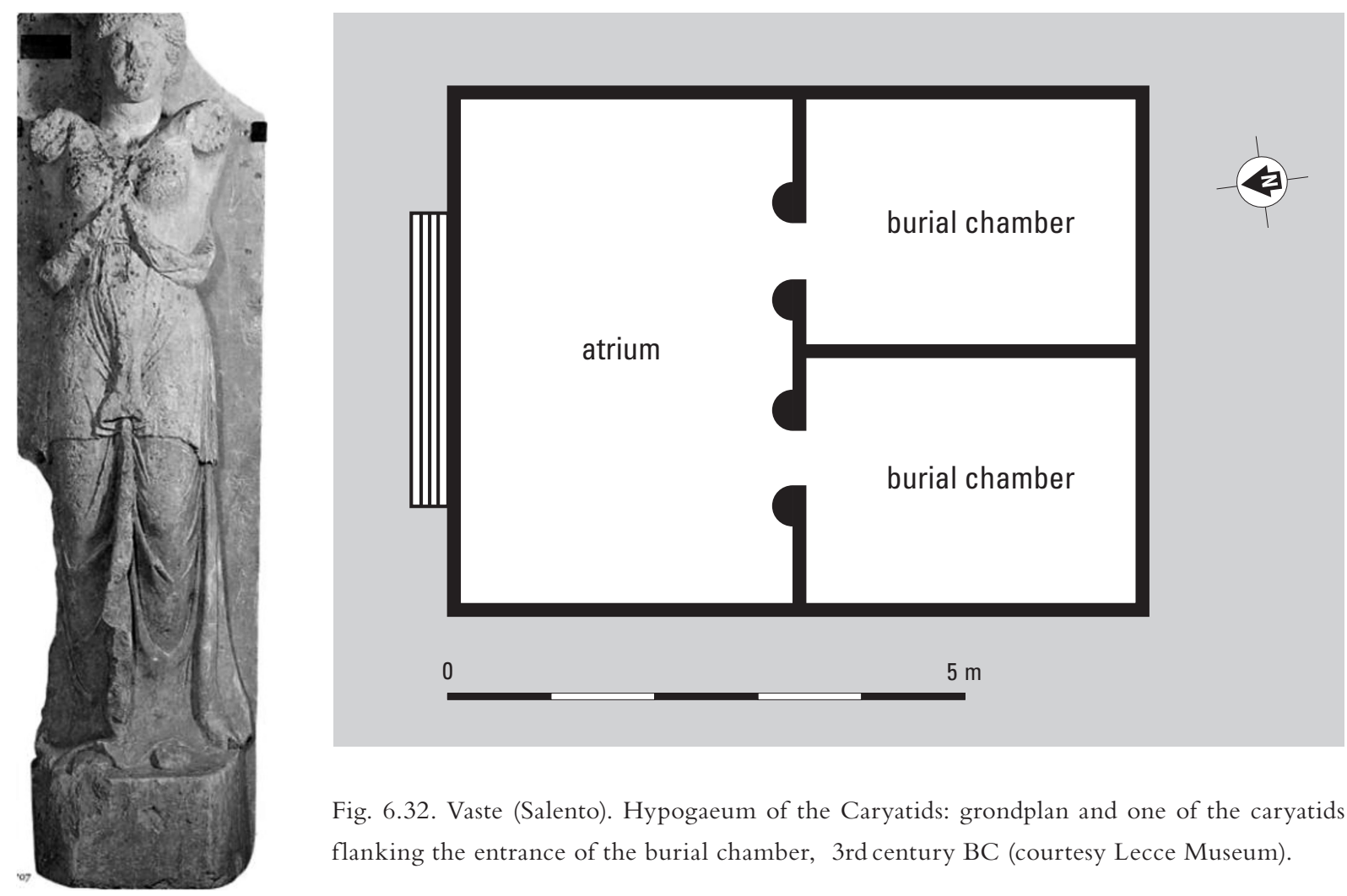

Fig. 6.32. Vaste (Salento). Hypogaeum of the Caryatids: grondplan and one of the caryatids flanking the entrance of the burial chamber, 3rd century BC (courtesy Lecce Museum).

those of the Canosa area. They usually consisted of one or two rooms painted in a manner reminiscent of Messapian houses (fig. 6.31). ${ }^{112}$ A few Salento chamber tombs had sculptured decoration (fig. 6.32). ${ }^{113}$ Nothing is known about the grave goods they contained since they were emptied in a distant past.

Not every Messapian chieftain of the 4th or 3rd centuries was buried in a hypogaeum. Especially in the Brindisi plain with its thick soils the prominent members of dominant lineages in the local clans were buried in large cist graves. These were enlarged versions of the tombs in which most Messapians were buried. We are well informed about the contents of such graves. ${ }^{114}$ As we have seen above, jewelry, mirrors, metal vessels, strigils, weapons and armour were indicators of high status. The range of metal vessels in the burials consists of jugs, wine sieves and basins which all relate to the symposium. ${ }^{115}$ Except for the metal vessels each of these categories of elite objects was gender-bound. Both jewels and mirrors are of the same types as those found in the graves of wealthy ladies of Taras. Armour and weapons however suggest martial prowess and have no parallels in Greek towns. The strigils, of course, refer to the palaestra and may suggest that the deceased was an educated person imbued with Greek paideia. It is uncertain whether this display of Greek paideia in late 4th and 3rd century graves corresponded to 'real' paideia during the lifetime of the deceased. ${ }^{116}$

112 On the ceilings of the tombs the beams were painted that supported the roof. In the 3rd-century houses of Valesio, moreover, small fragments of wall-painting were found in colours that match those of the hypogaea.

113 These two hypogaea are the Ipogeo Palmieri (underneath the 18th-century Palazzo Palmieri at Lecce) and the Ipogeo delle Cariatidi at Vaste; (see, for instance D'Andria 1988).
114 A generous sample of tombs from the southern Salento settlement of Vaste has been published recently; see Archeologia dei Messapi, 65-152; and Delli Ponti 1996.

115 Tarditti 1996.

116 There is substantial evidence that by the late $3 \mathrm{rd}$ century BC eminent Messapians were fluent in both Latin and Greek (see chapter 7, section 1). 


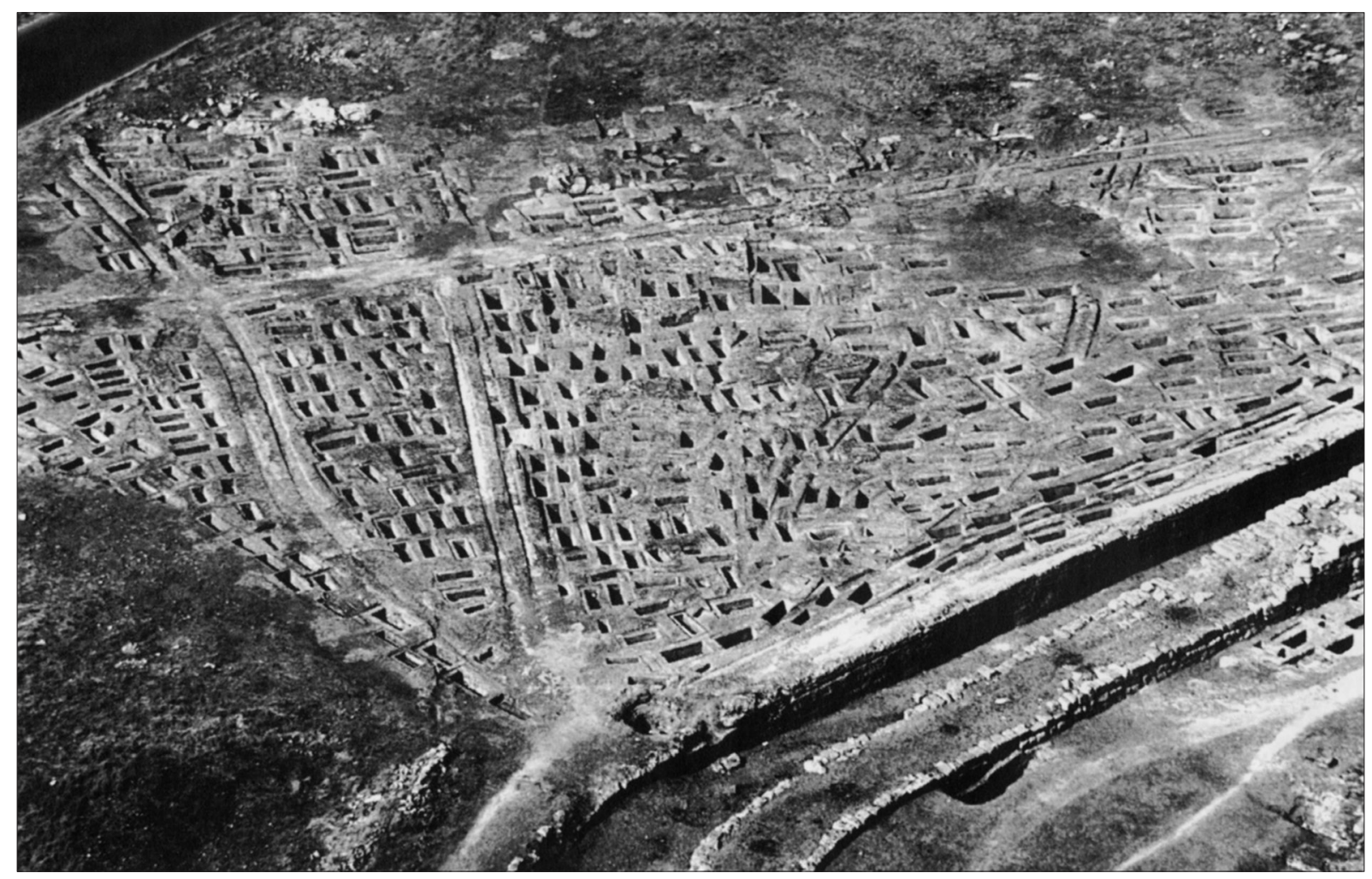

Fig. 6.33. Aerial photograph of the northern Cappucini necropolis at Manduria, first half of the 3rd century BC (photo archive ACVU).

The vast majority of graves in the Salento district, however, contained mainly ceramics. ${ }^{117}$ The varying quantities and qualities of these also seem to be rank-related. The assemblages of the grave goods are similar to those in Greek Taras. In the non-elite graves of Salento terracotta pouring vessels (jugs, oinochoai) and drinking vessels (skyphoi, kantharoi) are present in the graves of adults of both sexes, suggesting the consumption of wine. The graves of males, moreover, often have krater-like vessels (bell kraters, bowl krater, giant skyphoi) which complete the wine set. These non-elite assemblages seem to reflect elite burial in so far as the consumption of wine with somewhat symposiastic overtones seems to be central to the ideology behind these Messapian burial goods.

During the first half of the 3rd century BC signs suggesting change can be observed in the spatial organization of the cemeteries of Salento. It should be remembered that the burial grounds being closely linked to family and clan territories within the settlement area, were invariably small and dispersed during the later 4th century BC. From about the first half of the 3rd century BC, however, there is a tendency towards much larger, more coherent necropoleis showing a clear spatial organization. This innovation did not occur in every settlement of the district with the same intensity. The most obvious case is the site of Manduria (35 km east of Taranto). Here large numbers of systematically arranged graves (probably family plots) make up the northern necropolis of the settlement in a way that is similar to that of the necropoleis of the Greek towns of southeast Italy (fig. 6.33). This new feature may suggest that in at least some of the fortified settlements of Salento the importance of the community as a whole increased at the cost of the importance of family and clan structures.

117 The 4th- and 3rd-century tombs of the Salento district often contain Apulian Red-Figured, Gnathia wares,
Apulian Black Gloss and banded and plain wares (the last three classes are usually of local make). 

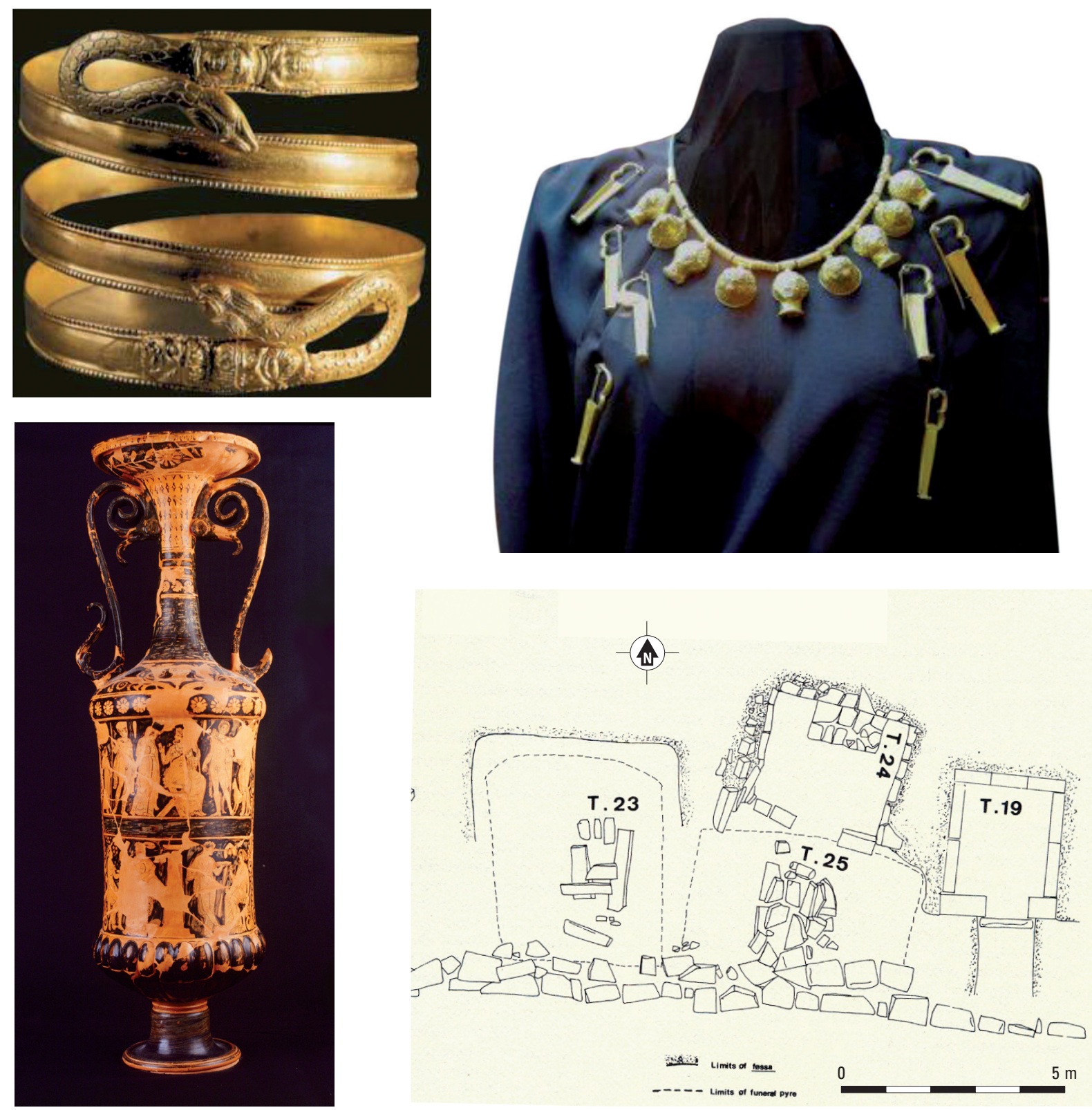

Fig. 6.34. Roccagloriosa: ornaments of a Lucanian lady (tomb 9), loutrophoros and plan of the La Scala elite necropolis, 4th century BC. Photos courtesy University of Alberta/Perugia.

Whilst there is an abundance of graves of the later 4th and 3rd centuries from the non-Greek districts of Apulia, the evidence published hitherto for the Lucanian areas of southeast Italy is much thinner for the period under discussion. In pre-Roman Basilicata hypogaea are conspicuous by their absence. The deceased are invariably buried (usually inhumation; in a few rare cases cremation) in cist graves or in trenches carved in the base rock. Their contents consist predominantly of decorated pottery. Among these are wares with figured and vegetal decoration (Lucanian Red-Figured, some Gnathia wares) and ceramics covered with a black gloss or decorated with horizontal bands. ${ }^{118}$ As in the graves of the Greek

118 The Lucanian Red-Figured wares and Gnathia wares are likely to have come predominantly from Metapontion (cf. D’Andria 1975a), whilst much of the Banded wares and Black Gloss wares in Lucanian burials were made in non-Greek settlements. 


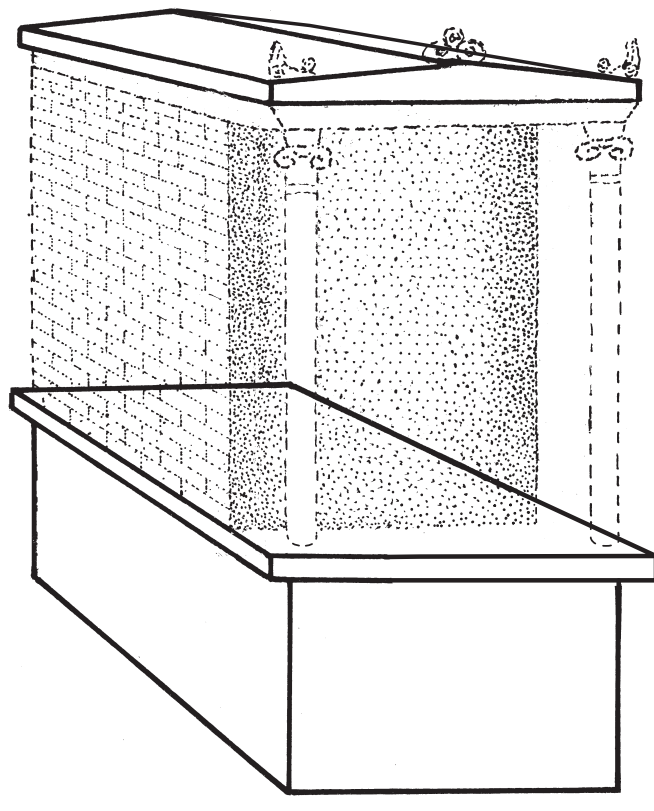

Fig. 6.35. Monte Sannace (central-Apulia). Heroon on the acropolis: archaic elite burial in Hellenistic setting (based on Donvito 1980).

towns and non-Greek Apulia, pots relating to the consumption of wine (e.g. kraters, oinochoae, various types of wine cups) are almost invariably present. A burial ground of Roccagloriosa in western Lucania has supplied evidence concerning elite graves. ${ }^{119}$ These often large cist graves have greater quantities of figured pottery, special forms of pottery (e.g. rhyta) and precious metal objects, such as gold necklaces and bracelets, and bronze 'Samnite' belts and strigils (fig. 6.34). ${ }^{120}$

In the narrative told by the vast majority of graves of southeast Italy the consumption of wine is a central element. In both the Greek states and the indigenous polities of southeast Italy wine jugs and wine cups were almost standard elements in the graves of both men and women. Kraters used for the mixing of wine and water are mainly found in male burials in the non-Greek districts. It has, therefore, been assumed that the characteristically Greek symposium was widely adopted by the non-Greek populations and that it was in fact a cultural feature shared by all South-Italians of the early Hellenistic Age. Another view on the same matter is that there was a general, widely shared Dionysiac background in southeast Italy. These two assumptions, however, are probably unfounded. It should be noted that the standard assemblage consisting of wine cup and wine jug is even encountered in the burial plots of the isolated farmsteads of tribal Salento, Since, moreover, these same two vessels are among the most frequently encountered vase forms in settlement contexts, one may suggest that jug and cup were among the daily necessities in the world of the living and that therefore these same objects accompanied the deceased in the otherworld. The presence of more elaborate wine sets (bronze jugs, sieves, basins) and strigils in the graves of important males in the non-Greek districts of Lucania and Apulia is perhaps more indicative of the acquisition of some basically Greek models and modes of behaviour. These objects suggest that banqueting and feasting in a symposium-like way may well have been practised among the non-Greek elites. It should, moreover, be remembered that elite dwellings (e.g. Roccagloriosa) and especially elite banqueting halls (e.g. Serra di Vaglio, Vaste) may be recognized in the architectural remains of non-Greek sites (see section 6.2).

Rituals were performed on many occasions and in many places of pre-Roman southeast Italy. Rituals took place in the case of burials. Ritual acts were equally performed in or near the dining halls where the local or regional elites of the Lucanians and Apulians gathered. The physical remains of a more or less distant past could also bring about ritualistic behaviour. We have no information on the way Greeks and non-Greeks of the Hellenistic Age dealt with Bronze Age tumuli that continued to be conspicuous features in the landscape to the present day. But a large 6th-century male burial on the highest and most central spot in the important settlement of Monte Sannace in central-Apulia was enshrined in a

119 Gualtieri 1990, Gualtieri / Jackes 1993.

120 Large, almost room-like cist graves, partly hewn into

the base rock and partly built of blocks and slabs are often referred to as tombe a semicamera in Italian. 
late 4th- to early 3 rd-century construction (fig. 6.35). To the person buried in that grave an obviously important role was assigned in the Hellenistic present. We shall never know whether he was considered to be a charismatic tribal chief or the founder of the settlement, but the architectonic setting suggests that he was believed to have special, possibly heroic qualities and that the local community greatly benefited from his continued presence in the very heart of the settlement of Monte Sannace.

Comparable spots must have existed in the Greek settlements of southeast Italy. These were, for instance, the places linked with the oikists who were closely associated with the assumed origin of the settlement. The stories concerning the origin of the Greek settlements were adapted, recycled or reinvented in order to be meaningful to the Hellenistic present. In the 4th century BC the Metapontines invented the new founder, named Leukippos, ${ }^{121}$ whilst Phalanthos, the official oikist of Taras, was outstripped by a probably local, dolphin-riding spirit who had the same name as the settlement. We have seen above why and how the poleis of southeast Italy created their first origo myths and how indigenous groups constructed their origins. Whilst the poleis assumed a Greek identity by means of, for instance, Iron Age oikists and close mental ties with a metropolis in Aegean Greece, indigenous polities presented themselves predominantly as descendants of Bronze Age Greeks (chapter 5, section 7). The Iapygians, Daunians and Peucetians descended from Iapyx, Daunios and Peucetios, sons of the Greek Lykaon or the Cretan Daidalos. The Lucanians were either assigned a Samnite ancestry or were said to derive from the Arcadians of the central Peloponnesus. In southeast Italy, therefore, Greeks and non-Greeks competed for distinguished origins. Obviously, a noble origin was a Greek origin, since in most of these origo myths native groups portrayed themselves as arch-Greeks by linking themselves to the heroic age of Greece.

As a result of these stories mythic Greeks who were generally believed to have lived in the Bronze Age, were worshipped in non-Greek settlements as, for instance, Diomedes in north-Apulian Arpi. ${ }^{122}$ Mythical Greek heroes entered into the supernatural world of non-Greek groups and were obviously meaningful to them. The first traces of these Greek heroes in non-Greek contexts date to the 6th (?) and 5th centuries BC, but they are most persistent for the Hellenistic Age. Native elite families, for instance, may well have claimed descent from a Greek hero, underlining in this way perhaps the unusual character of their lineage and the legitimacy of their special position in their local or regional society.

Sacred places have a distinct tendency to occupy fixed points in urban and rural landscapes of the past. The spirits worshipped there are obviously closely associated with that particular spot. Sanctuaries often survive drastic socio-political changes and as a rule display a very considerable degree of continuity. This observation holds good for many districts of southeast Italy. In the Greek towns and their territories the location of both the urban and the rural sanctuaries of which the earliest recognizable phase can be dated to the late 7th or early 6th century BC, continued to be the same. In the 4th and early 3rd centuries the temples of Taras and Metapontion were no less the symbols of local pride and prosperity than in the 6th and 5th centuries BC. Rural sanctuaries in the territories of the Greek towns show the same continuity. The main novelty in these areas for the 4th and 3rd centuries is that the demographic growth and the prosperity for all that characterize the later 4th and early 3rd centuries, also shows at the cult sites. The originally simple and hardly conspicuous rural cult place at Pizzíca Pantanello in Metapontion's chõra was transformed into a substantial sanctuary that was a clear mark of religious activity in the landscape(fig. 6.36). ${ }^{123}$ In almost every sanctuary in the Greek territories the number of artefactual votive offerings increased very considerably during the 4th century BC. ${ }^{124}$ Foremost among these were pots, terracotta statuettes and foodstuff.

121 See, for instance, De Jullis 2001, 22.

122 Van Compernolle 1988, 117.

123 The sanctuary of Pizzica Pantanello is approximately 1 $\mathrm{km}$ east of the necropolis of the same name (see Carter 1994 and 1998b). 

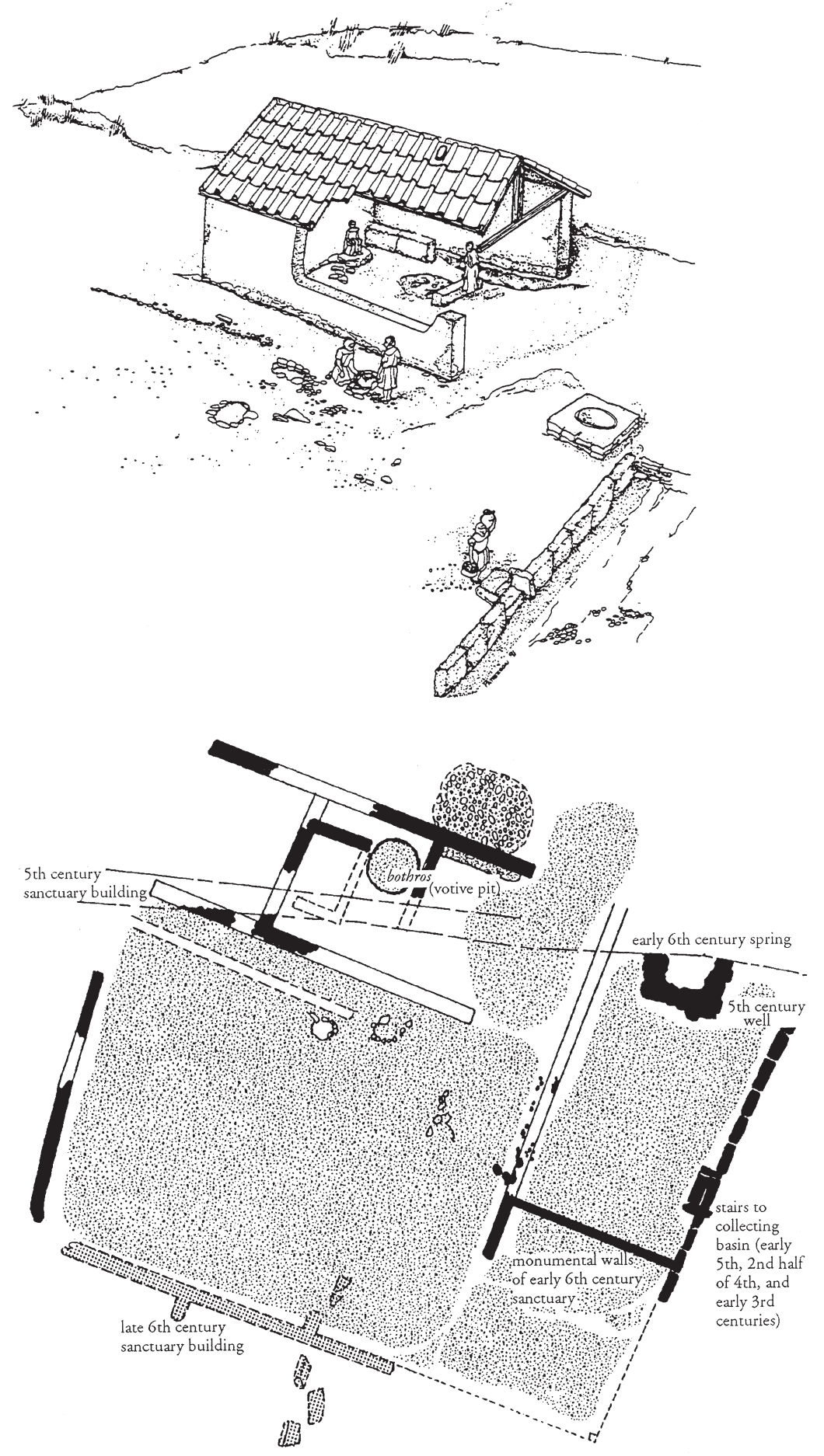

Fig. 6.36. Rural sanctuary at Pizzíca Pantanello (territory of Metapontion), 4th-century BC phase (after Carter 1998).

In the sacred sphere the Italiotai of Thourioi, Herakleia, Metapontion and Taras did not stick exclusively to the traditional Greek pantheon. ${ }^{125}$ The shifts in religious conceptions and the perceptions of the sacred in southeast Italy were comparable to those in Aegean Greece. The 6th- and 5th-century $\mathrm{BC}$ temples continued to be important landmarks in the poleis, being anchorages of both local religion and local identity. While the traditional gods inhabiting the traditional sanctuaries continued to play 
an important role in public rites and ceremonies, more individual forms of religion came to the fore in the course of the 4th century BC. Among these the Orphic and Dionysiac trends were predominant. These are both characterized by less pessimistic views on afterlife than traditional Greek religion. Orphism is likely to have been somewhat elitist. ${ }^{126}$ The cult of Dionysus - already quite diffused by the early 5 th century $\mathrm{BC}$ - became very popular with both the elite and the masses. It continued to play an important role, especially in Taras to well within the 2nd century BC. The cartloads of terracottas from the votive pits in the Taras sanctuaries of this deity seem to confirm his great popularity among large groups of the local population. ${ }^{127}$

The study of religion in the non-Greek societies of pre-Roman Italy is still in its infancy. As we have seen in chapter 5 , it was not until the late 6th century BC that religious activities can be recognized in these districts. It is especially in southern Apulia and the Metapontion hinterland that these early traces of non-Greek religion have been found. The sacred places continued to function during the later 4 th and 3rd centuries. There is a good deal of information about finds consisting of votive offerings, but evidence concerning the spatial organization of sacred places is scarce. By the 4th century BC, however, the legible signs of religious activity become much more numerous. Votive deposits of the 4 th and 3 rd centuries often contain huge quantities of offerings.

In southern Apulia the sacred places of the Messapians were often cave sanctuaries. These were usually outside the settlement areas. The votive objects presented to the deity were deposited in the caves or on terraces in front of the caves. The presence of ashes in the votive deposits (bothroi) indicates that ritual burning played a role in the regional cults. The settlement of Oria on the Salento isthmus between Taranto and Brindisi had a sanctuary of probably regional importance since the 6th century BC. The originally open-air sanctuary was monumentalized during the 4th century by means of terracing and the construction of a set of adjoining and intercommunicating rooms suggesting a somewhat mystic setting. These rooms were constructed on a terrace in front of the cave that was probably the most sacred part of the sanctuary. At Oria the numerous votive offerings were deposited in large pits (bothroi) in the terraces in front of the cave. ${ }^{128}$ In addition the artefactual objects, cakes, pomegrenades, corn, beans and other types of food were offered to the deity or deities of the sanctuary. ${ }^{129}$

The Oria sanctuary has not supplied the names of its $\operatorname{god}(\mathrm{s})$. The votive offerings found here have such close parallels in Italiote sanctuaries of Demeter and Kore, that these vegetation goddesses or their native equivalents are believed to have been worshipped here. In other cases, however, the names of the deities were carved in the walls of the caves or scratched into votive objects presented to the god. At Cape Leuca, the southernmost tip of Apulia, we encounter Zis Batas. ${ }^{130}$ In addition to him we find the names of Thaotor (Latinized: Stator or Tutor) at Rocavecchia, Thana at Porto Cesareo, whilst 'priest(ess) of Damatira' is incised on the lids of various cist graves.

The Lucanian sanctuaries have received more attention than those of southern Apulia. ${ }^{131}$ They seem to appear in the later 5th century and vary considerably in form and setting. A few of these are small (mostly within the settlement area), but the larger specimens are situated outside the walls at one to two $\mathrm{km}$ from the settlement. Each of the larger sanctuaries, therefore, is closely linked with one specific walled settlement and cannot be seen as a rural cult place. There must have been a road linking the settlement to its sacred place. As for their form, they are basically enclosures with or without cult building. They are, moreover, located near spots where water comes to the surface. Obviously water was vital in the religion of the Lucanian districts. These cult places have no standard set of compo-

\footnotetext{
126 Pugliese Carratelli 1988.

127 Iacobone 1988; De Juliis 2000.

128 D’Andria 1990, 239.

129 Ciaraldi 1999; Fiorentino 2008.
}

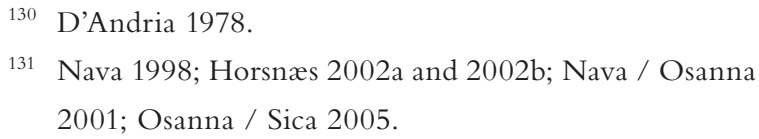




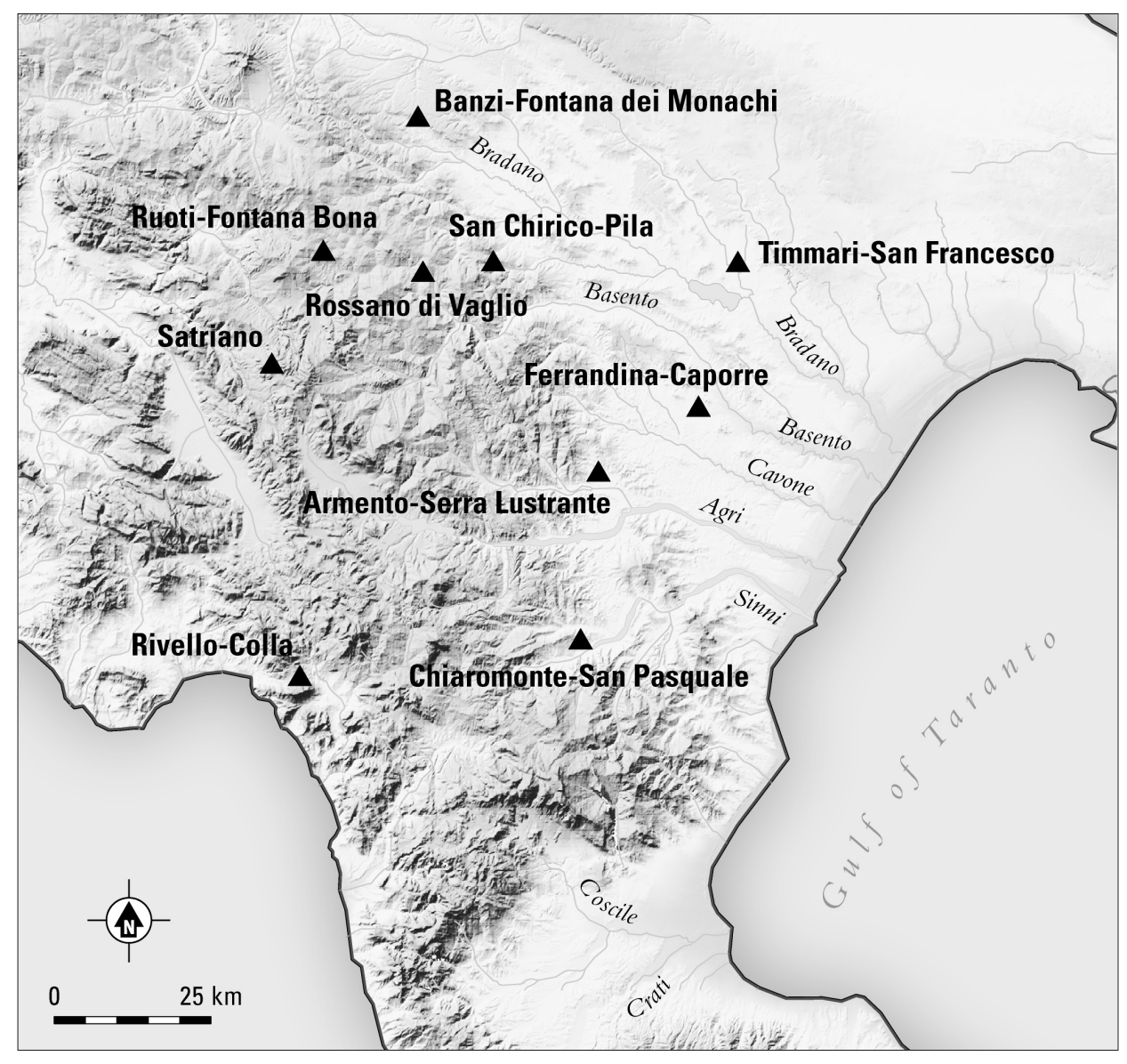

Fig. 6.37. Sacred places of local or regional importance in non-Greek Basilicata, 4th and 3rd centuries BC.

nents. Often, however, the Lucanian sanctuaries consist of a shrine, an altar and a dining room, while constructions related to water (e.g. basins, cisterns, sacred wells) are invariably present (fig. 6.38). The various components are usually linked by a kind of processional road.

The important sanctuary of Rossano di Vaglio high up in the mountains of central Basilicata probably had a standard set of components (fig. 7.11). ${ }^{132}$ Among the sacred places of the Lucanian uplands it stands out in several respects. It is much larger than any other sanctuary in the uplands of Lucania and has an enormous 4th-century altar measuring $27.25 \times 4.5 \mathrm{~m}$. Its distance to the nearest settlement, moreover, is substantially larger than usual and it survived much longer than other sanctuaries of preRoman Basilicata. ${ }^{133}$ The nearest site is Serra di Vaglio (6 km to the southwest) which - as we have seen - is likely to have been the major tribal centre in central Basilicata from the late 6th century onward. Because of its unusual size, its unusual history and its unusual location, the sanctuary of Rossano di Vaglio is likely to have been a religious centre of more than local importance. Often it is believed to have been the large tribal sanctuary, where all the local leaders of the nomen Lucanum and their Gefolgschaft assembled at well-defined occasions. They did so probably in order to elect or confirm

132 Our information on the 5th to 3rd century phases of the sanctuary of Rossano di Vaglio is scant, because it was thoroughly rebuilt in the 2 nd century BC.

133 See Adamesteanu / Dilthey 1992; Torelli / Lachenal 1992, 62-90. The sanctuary of Rossano di Vaglio probably originated in the 5th century (Bottini 1988, 74), but had its most buoyant phase in the later 3rd and 2nd centuries BC when other sanctuaries were already in decline. 


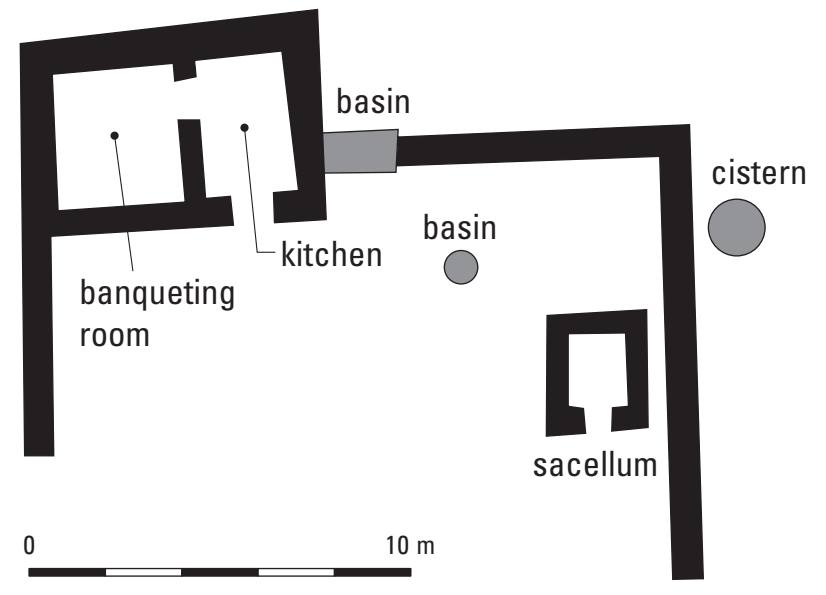

Fig. 6.38. Armento-Serra Lustrante (Basilicata): plan of the 4th century phase of the sanctuary. After Russo Tagliente 1995.

their supreme leaders under the supervision of the local deity. ${ }^{134}$ At the Rossano sanctuary they may also have stressed their allegiance to supreme leadership, their tribal cohesion and their tribal identity by performing rites for the spring goddess Mefitis. Banqueting with a small group was part of the rites. Whilst the central leadership of the Lucanian supertribe possibly had its residence at Serra di Vaglio, the rites that conferred and restated special powers within the Lucanian socio-political order were performed in the religious context of the sanctuary of Rossano di Vaglio in the presence of the great goddess.

Changes in social organization of societies are often reflected in changes in the settlement patterns. In the uplands of Lucania the data supplied by the cult places are equally indicative of far-reaching changes in this same field. They echo the genesis, the increased tribal organization and the increasing social hierarchy of the Lucanian supertribe. Most cult places started as recognizable archaeological features in the course of the 5th century BC. As we have seen, this was a time of profound changes in which various local groups clustered into the Lucanian confederation. The rise of these cult places coincides with the appearance of the Lucanian confederation in the ancient written sources. Increased political organization in the Lucanian districts went hand-in-hand with the appearance of 'legible' sacred places. In the later 4th century BC, the sacred precincts were adorned with buildings and constructions related to water. This monumentalization of the sanctuaries was, therefore, contemporary to the monumentalization of the settlements and the creation of an inhabited countryside. The cult buildings, basins and dining rooms of the sanctuaries were developed at the same time as the imposing fortifications and the isolated tribal farmsteads. Most sanctuaries of Lucania served local tribal groups living in such imposingly fortified oppida. The higher level of political organization of the confederation or supertribe is reflected in the probably pan-Lucanian sanctuary of Rossano di Vaglio, only $6 \mathrm{~km}$ from the supra-regional centre of Serra di Vaglio where the largest dwelling of pre-Roman southern Italy could be found (see fig. 6.20). This could have been the ceremonial home of the paramount chief of the Lucanians in which he discussed matters of Lucanian policy and dined and feasted with cantonal and local chiefs, whilst the sanctuary at nearby Rossano was the place where he displayed himself in the rituals and ceremonies to much larger groups of Lucanians.

The smallness of the banqueting rooms in the local sanctuaries is another indication of changes in the social sphere. Since they could contain only a handful of people, their sheer size suggests that they had an important function in marking social boundaries within the settlement. Those who were allowed to dine within the domain of the god belonged to a special group: it was probably the prerogative of the local elite to participate in banquets in the sacred atmosphere of the local sanctuary. This legitimized their special position within the local society. Those who were denied this prerogative

134 A 4th-century inscription found near the fortifications

of Serra di Vaglio tells us in Greek that something happened 'during de leadership of Nymmelos' (ЕПI

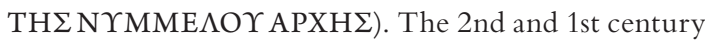
inscriptions from Rossano di Vaglio tell us about magistrates/leaders named meddices. 
were undoubtedly less influential members of the clan or family groups dependent on the persons who were allowed to participate. Since the construction of these relatively small banqueting rooms in local sanctuaries and the construction of elite houses with very similar banqueting rooms are approximately contemporary, it is plausible to assume that the local elites of Lucania became more marked and more conspicuous in the later 4th century BC. They demonstrated their elite status in, for instance, their dwellings and their participation in banquets in both the political (elite house) and sacred (sanctuary) sphere.

The preceding passages indicate that religion in both Basilicata and southern Apulia had become more and more complex during the 4th century BC. Increasing complexity often generates specialists. It is indeed in the later 4th century that we can trace the first specialists in the religious sphere. Inscriptions in the Messapic language of southern Apulia mention persons called tabaras or tabara. Since these terms are often followed by the name of a deity, it is plausible to assume that these were priests or priestesses that played a role in performing the rites for the deity mentioned in the inscription. ${ }^{135}$

The traces of religious activity suggest that the sacred was a complex matter in southeast Italy in the later 4th and 3rd centuries BC. There was a variety of traditional Greek cults in the four Greek towns and their territories. In addition to these there were Orphic and Dionysiac tendencies the true character of which is hard to reconstruct from the archaeological record. Moreover, we find many traces of religious activities in both Oscan-speaking Lucanian and Messapic-speaking Apulian districts. Their religions probably differed enormously. Both non-Greek Lucania and Apulia adopted elements derived from Greek cult practices (e.g. the deposition of votive offerings such as pots and terracotta statuettes, the ritual burning of non-artefactual offerings). They differed, however, vastly in their pantheons, their rituals and the way they laid out their sacred places. The Messapian pantheon shows signs of Greek influence (e.g. Zis = Zeus, Damatira $=$ Demeter), but the deities named Batas, Thana, Thaotor suggest that this Greekness may only be a thin veneer. The Lucanian water goddess Mefitis and the rites performed in her sanctuaries seem to confirm the strongly native character of the religion in upper Basilicata.

\section{4 . C R A F T}

The surviving 4th- and 3rd- century objects and features by far surpass the quantities of finds from any preceding period. They are probably even more numerous than those of all the preceding centuries of the first millennium BC taken together. Initially, much of the 3rd century was believed to be absent, since the Roman conquest was supposed to have put and end to the prosperous societies of southeast Italy (see introduction to chapter 7). Recent investigations, however, have shown that this supposition is unfounded and that both Greeks and natives of southeast Italy continued to flourish for many decades after the Roman victories over the Lucanians, the Messapians and the Italiote League.

One of the reasons for this abundance of material evidence is than many settlements of southeast Italy were gradually abandoned (partly or completely) between the late $3 \mathrm{rd}$ and the late 2 nd century BC: the 4th and 3rd centuries were often the most recent, 'solid' and prosperous phases not built over and not destroyed by intensive habitation of subsequent, more recent phases. A second reason for the abundance of artefactual evidence concerning the 4th and 3rd centuries BC is that southeast Italy was more prosperous and more populous than ever before in the period under discussion (see section 4.2). This vast area was now much more densely inhabited than in both preceding and subsequent centuries

135 Bottini 1988, 63.

136 These features were less pronounced in northern $\mathrm{Apu}-$ lia where Iron-Age techniques and production methods persisted to within the 4th century BC. 
and these much larger numbers of more prosperous people used large quantities of artifacts. A third factor contributing to the abundance of the artefactual evidence is funerary custom. In many areas of southeast Italy the 4th-century tombs are richly furnished and extremely numerous. Generally speaking, moreover, there is a truly exponential increase in the number of burials. This increase was not exclusively the result of demographic growth, but must also be ascribed to changes in funerary customs. A higher percentage of the people that made up the local societies, was granted a formal burial. Prosperity, demographic growth and lavishness in the funerary sphere together, therefore, can be held responsible for the high visibility of the period under discussion.

We have demonstrated in the preceding chapter 5 that the 6th and 5th centuries BC saw very considerable changes in craft. Among the innovations that characterize this period were serial production and standardization. Of course, the tools that created the opportunities for these developments (e.g. changes in the organization of craft, craft specialization, the introduction of the quick potters wheel), found wide acceptance in nearly every district of southeast Italy. ${ }^{136}$ Initially, however, it was predominantly in the Greek towns that the wide variety of 'industries' was found. By the 4th century BC craft became still more standardized and specialized here, while the variety of products made by the local craftsmen was large. In the later 4th century BC, each settlement of some standing in the region under discussion had a considerable group of full time craftsmen. These produced a wide variety of highly standardized artifacts for a wide variety of different purposes. It was not just the Greek-speaking towns that displayed this amazingly wide scale in crafts during the 4th and 3rd centuries BC: the settlements of non-Greek Basilicata and Apulia had a comparable richness and variety of artifacts during the same centuries. Many of these were made by local craftsmen.

These developments are only weakly illustrated by architectural remains in the Greeks towns of southeast Italy. They had a considerable variety of building types by the early 5 th century BC (sacred buildings, stoai, town houses, farmsteads, fortifications, chamber tombs, cist graves etc.). By the 4th century BC the types of buildings that were constructed were approximately the same, but there was, for instance, a much greater variety in house forms that responded to more subtle differences in the social stratigraphy of that time. The main novelty in the field of architecture was the theatre. Buildings of this type were mainly constructed in the later 4th century BC. Metapontion is the only settlement of the area under discussion where such a building that could accommodate thousands of people, has been intensively studied. ${ }^{137}$ Taras and other poleis of Magna Graecia (e.g. Lokroi, Elea) can also be shown to have had a building of the same type (fig. 6.39), but they are conspicuous by their absence in the non-Greek areas.

In was in the indigenous settlements of southeast Italy, however, that the most impressive changes occurred. As we have seen, most of these were walled for the first time and had a large variety of house forms in the 4th century BC. Though the quarrying of the blocks is not necessarily specialized labour, the foundation of the heavy walls, the fitting of the blocks and the organization of labour must have required specialists who were planners and overseers. We have, moreover, seen that centrally planned quarters having insulae with almost identical houses were built in both Greek and non-Greek settlements (see fig. 6.16 and fig. 6.19). This suggest that the construction of a house was no longer an activity carried out by a family group, but was becoming the métier of a group of specialized builders who received orders from a central authority. The production of tiles covering these dwellings, storage sheds and other types of buildings, moreover, required yet other specialists.

137 For instance, Mertens / De Siena 1982. 
The most lavish and often conspicuous type of artifact found in southeast Italy in the period under discussion is pottery. The tendency towards increasing craft specialization is especially marked in the production of this particular class of objects. We have seen that substantial changes affected the pottery production during the 6th and 5th centuries. These changes included, for instance, standardization of the quality, shape and decoration. They were especially marked in the Greek towns of southeast Italy. During the later 4th and 3rd centuries, however, a wide variety of ceramics displaying a wide variety of standardized forms was made in almost every settlement of some importance of southeast Italy. By that time, for instance, vessels covered with a more or less shiny black to dark brownish gloss were made in many non-Greek settlements. The production of these so-called Apulian Black Gloss wares had been the prerogative of the Greek towns (especially Taras and Metapontion) since approximately 480/470 BC. ${ }^{138}$ Settlement contexts suggest that these Apulian Black Gloss wares had become the standard table wares in both the Greek and the native settlements by the late 4th century BC. The most common black gloss forms here are skyphoi and kantharoi (for the consumption of wine), plates and platters (for solid food) (fig. 6.40).

In addition to these fine Black Gloss table wares (1) there were two other classes of household pottery in southeast Italy: (2) Banded and Plain wares and (3) Coarse Cooking wares (fig. 6.41). Whilst Banded and Plain wares were light surfaced pots with or without painted horizontal bands, the coarse wares were brownish to blackish pots with a heavy tempering consisting of non-plastic particles. ${ }^{139}$ Both of these classes performed specific functions in the Greek and non-Greek households. The most common forms in Banded and Plain wares were hydriae, lekanai, jugs, various types of bowls and pithoid jars. Most of these were used for the storage and preparation of food or performed other household duties. The coarse wares were used for the cooking and baking of food. The pots of this second category were uncommon in the non-Greek settlements during the 6th and 5th centuries, but attained a great popularity here in the late 4th century. All of a sudden a large number of non-Greeks started to prepare food in the Greek way: the stew pots and casseroles of southeast Italy had a patently Greek ancestry. The same holds good for the vast majority of Black Gloss wares and Banded and Plain wares. Clay analyses and the discovery of kiln sites, however, have shown that these classes were all made in southeast Italy. ${ }^{140}$ By the later 4th century BC the ceramics used for everyday activities in both the Greek poleis and the indigenous settlements were pots with a decidedly Greek pedigree produced in a typically Greek manner..

The sudden and rapidly increasing popularity of cooking wares indicates that the preparation and consumption of food underwent enormous changes in southeast Italy during the 4th century BC. The Italiote Greeks probably continued to prepare their daily meals in ways that did not differ much from those of the 5 th century BC. ${ }^{141}$ My general impression is that the variation in shapes increased in the

138 The black gloss wares of southeast Italy represent a more or less independent branch of the widely diffused black gloss wares. The settlements of southeast Italy shared the same set of forms that evolved in this area in the same way at approximately the same moment (see Yntema 2001, 137-140). The tradition started in the 2nd quarter of the 5 th century BC in Metapontion (and probably Taras) and began to wane in the 1st century BC. The name 'Apulian Black Gloss' is basically not correct, since this class was diffused in both Apulia and large parts of Basilicata. Northwestern Basilicata (e.g. Roccagloriosa and surrounding district) used vessels stemming from a different branch of the black gloss tradition (Paestum/South-Campanian).

139 These non-plastic elements in the clay consisted mostly of sand, particles of ferro-manganese and small chips of limestone in southeast Italy. This tempering was added to the pots in order to make them resistant to thermal shock.

140 Kilns of the 4th and 3rd centuries have, for instance been unearthed at Taras, Metapontion, Herakleia and Valesio.

141 Usually little attention is paid in publications to the undecorated, light surfaced plain wares and the heavily tempered, dark surfaced cooking wares. For the poleis of southeast Italy, evidence concerning these ceramic classes is practically non-existent (for cooking wares from south-Italian Lokroi, see Conti 1989); for the cooking wares from the native site of Gravina di Puglia, see Small et al. 1992, 179-194. 

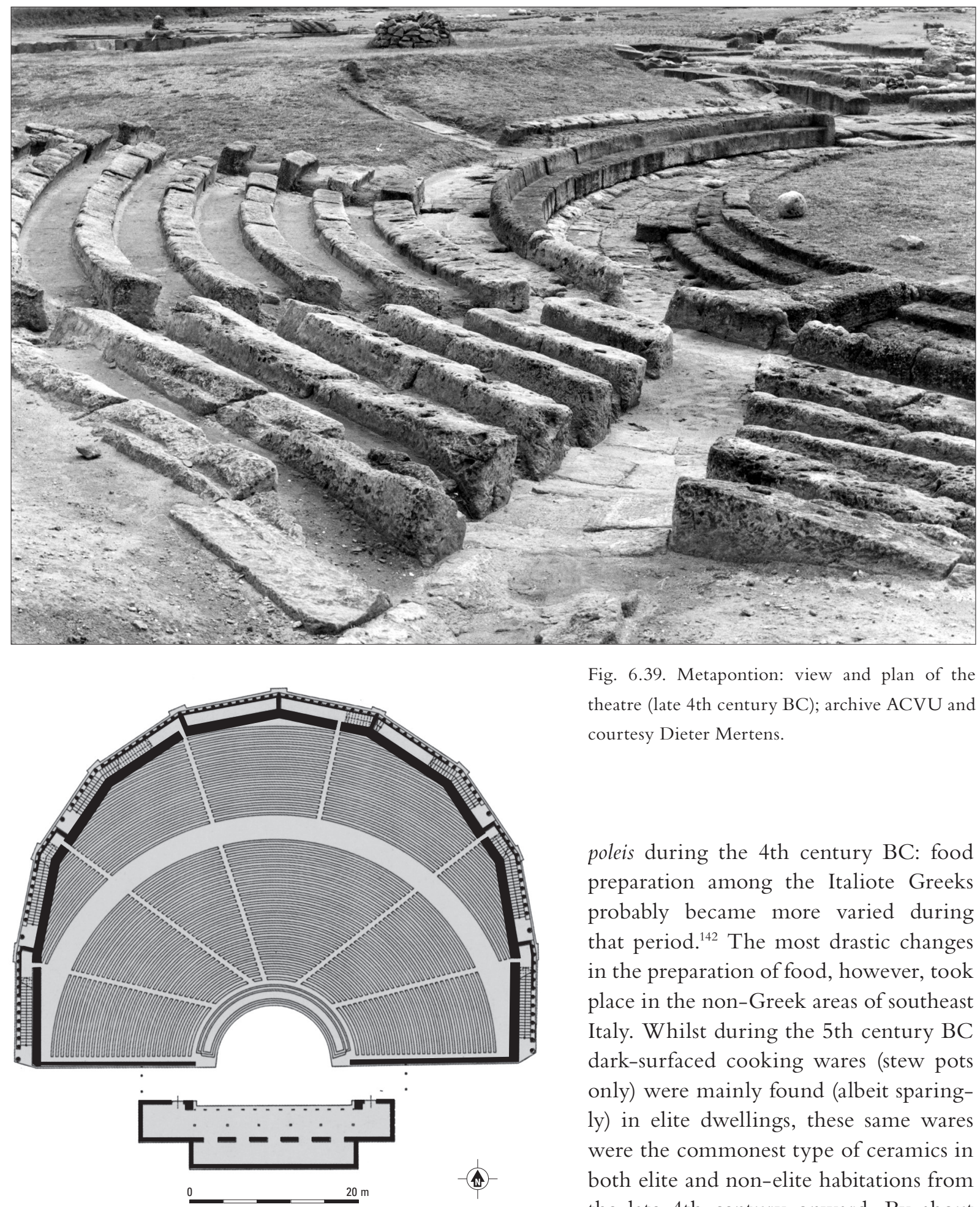

Fig. 6.39. Metapontion: view and plan of the theatre (late 4th century BC); archive ACVU and courtesy Dieter Mertens.

poleis during the 4th century $\mathrm{BC}$ : food preparation among the Italiote Greeks probably became more varied during that period. ${ }^{142}$ The most drastic changes in the preparation of food, however, took place in the non-Greek areas of southeast Italy. Whilst during the 5th century BC dark-surfaced cooking wares (stew pots only) were mainly found (albeit sparingly) in elite dwellings, these same wares were the commonest type of ceramics in both elite and non-elite habitations from the late 4th century onward. By about

142 The contexts that I happened to notice in museum exhibitions and deposits, suggest that the roundbodied stew pots (the chytra in Sparkes / Tallcott 1970) were present in the poleis of southeast Italy before the end of the 6th century BC. During the (later?) 5th

century the casseroles made their appearance (the lopas in Sparkes / Tallcott 1970), but they did not occur in large numbers before the 4th century BC, whilst frying pans were current from the late 4th century onward. 

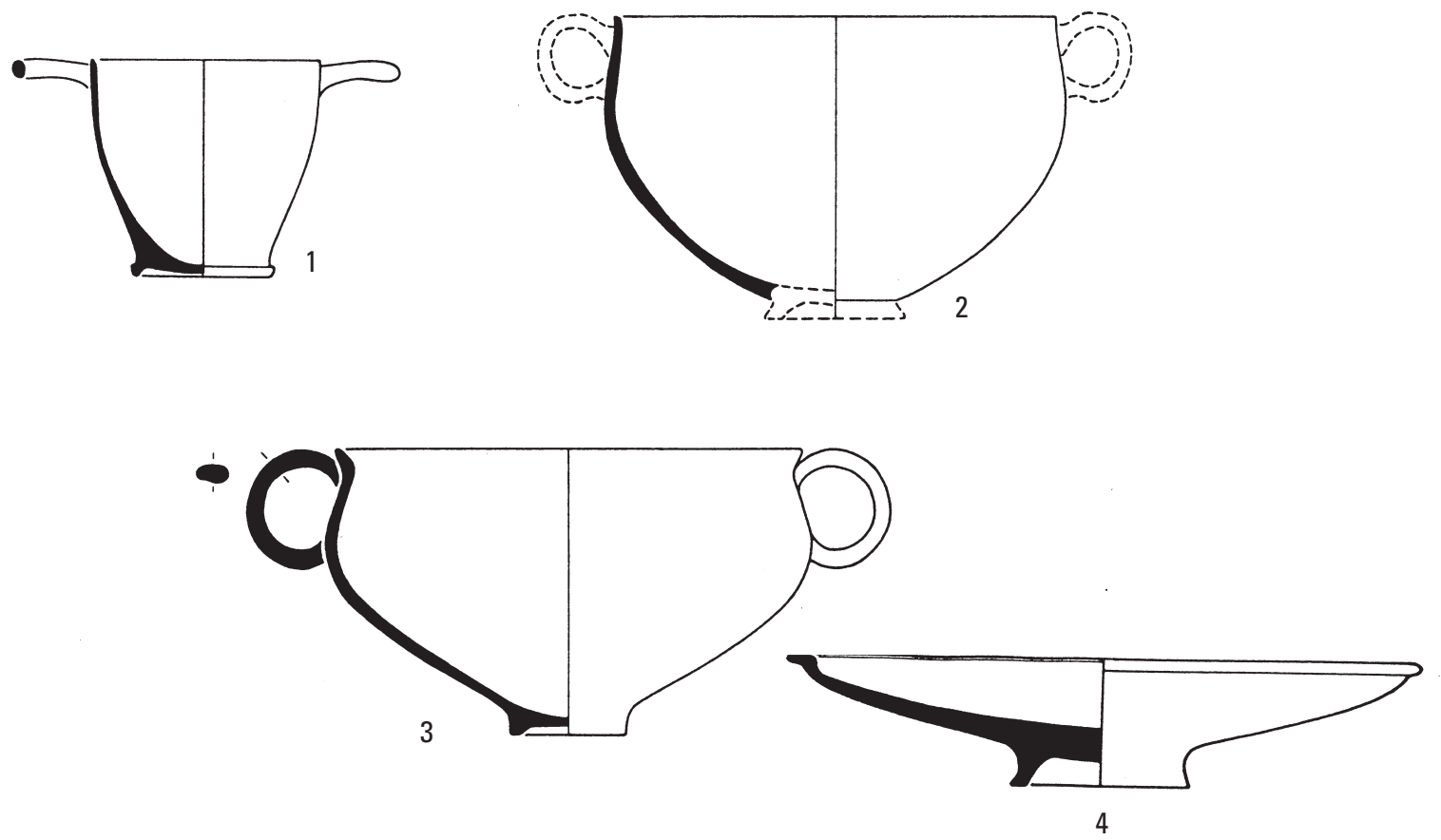

Fig. 6.40. Most commom Black Gloss forms of southeast Italy in settlement contexts between c. 350 and c. 230 BC. 1 skyphos (c. 350-275 BC); 2 kantharos (c. 325-275 BC); 3 kantharos (c. 275-225 BC); 4 platter (c. 325-275 BC).

$300 \mathrm{BC}$ the inhabitants of the Greek towns on the coast and the native elites and their tribal farmers all used the same wide range of cooking pots. This suggests that they all prepared the same types of food in approximately the same ways.

Whilst Black Gloss wares, Banded and Plain wares and coarse cooking wares (all ceramics predominantly produced for everyday use) were made in probably every settlement with a few thousand inhabitants, the production of lavishly decorated pottery continued to be the prerogative of the poleis of southeast Italy for many years. As we have seen, the workshops producing these so-called Apulian and Lucanian Red-Figured wares started in the third quarter of the 5th century BC. They were probably located at Taras (Apulian branch) and Metapontion (Lucanian branch) and initially produced a relatively limited quantity of red-figured pots. ${ }^{143}$ Around 380/370 BC, however, their output began to increase very substantially. The Apulian branch in particular produced enormous quantities of redfigured pots in the last decades of the 4th century BC. ${ }^{144}$ These Italiote workshops, moreover, made their ceramics for a very specific market. The vast majority of the red-figured vases painted in the workshops of Taras and Metapontion ended up in tombs, predominantly those of the tribal groups of southeast Italy.

143 For Lucanian Red Figured and Early Apulian Red figured, see Trendall 1967 and Trendall / Cambitoglou 1978. In addition to these, Apulian and Lucanian branches there were of course the Paestan, Campanian and Sicilian branches of red-figured pottery in 4th-century BC southern Italy. These produced redfigured wares in districts which are outside the scope of this book.

144 For Late Apulian Red Figured, see Trendall / Cambitoglou 1982. 

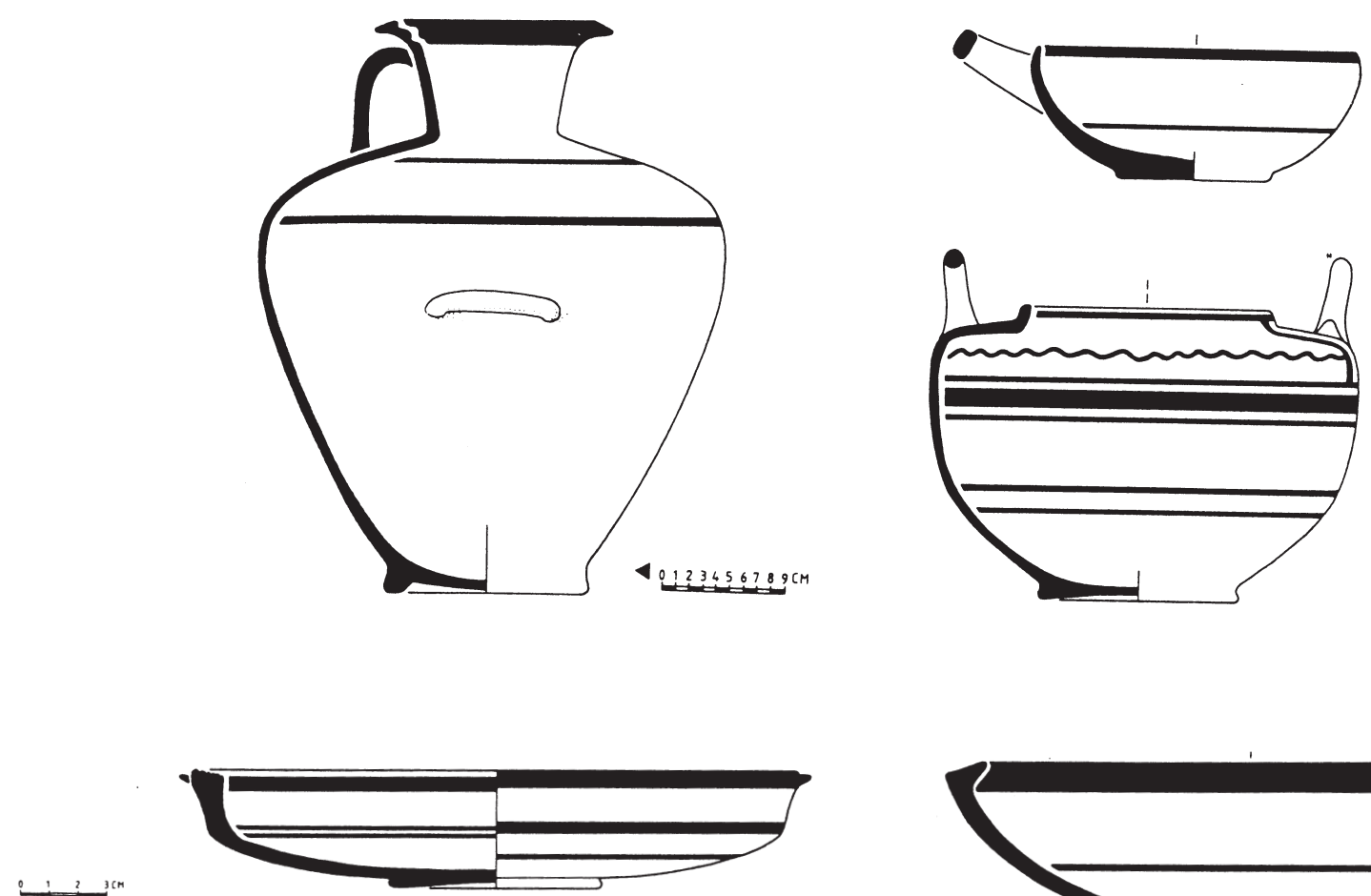

a
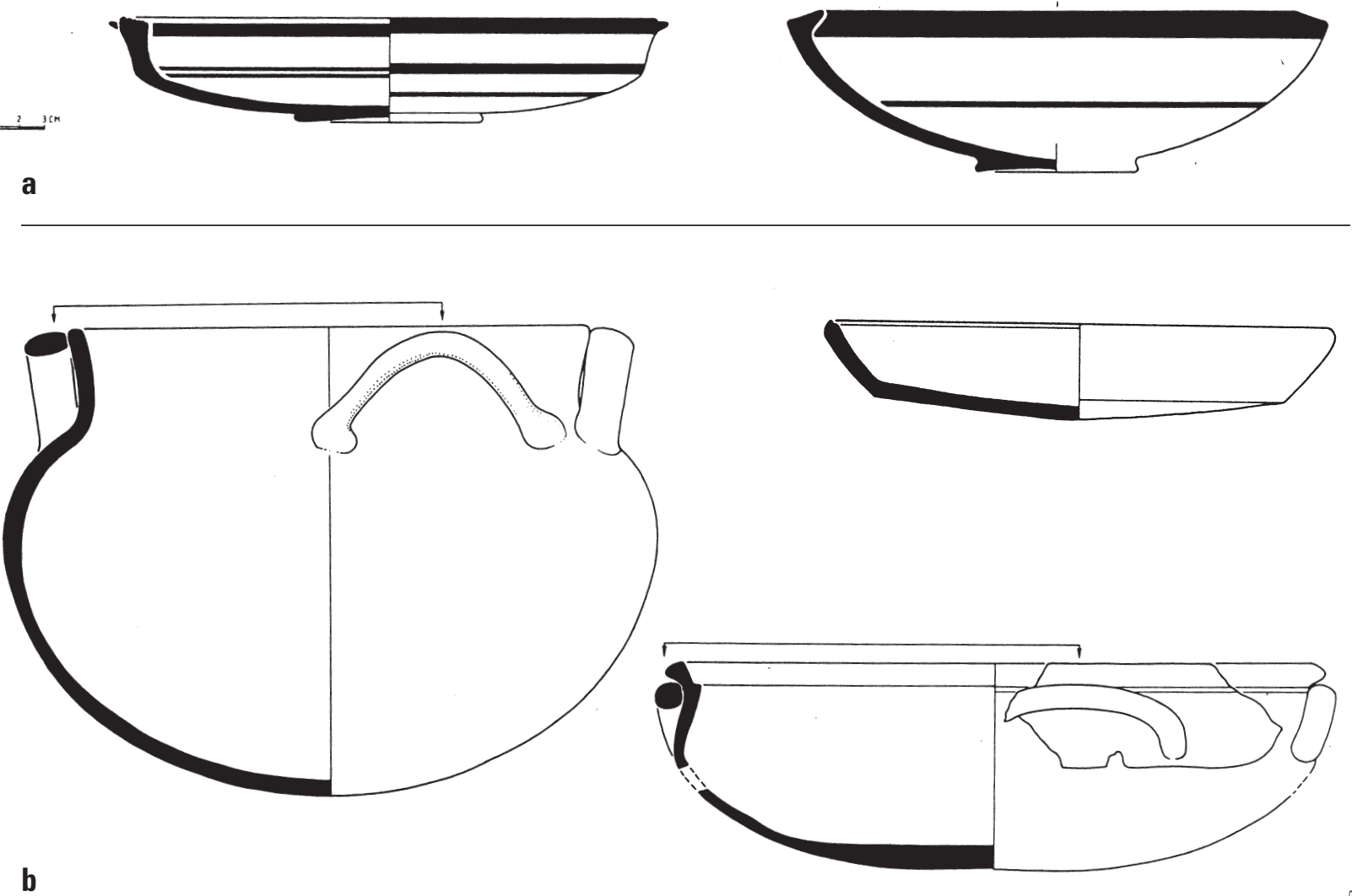

Fig. 6.41. Valesio (Salento district, south Apulia): ceramic forms commonly found in settlement contexts of the 3rd century $\mathrm{BC}$, fine wares, see fig. 6.40). (a) Banded and Plain wares; (b) Coarse Cooking wares. 
The scenes painted on the red-figured pots were not especially designed for the purposes served by the vessels themselves. They cover a wide variety of subjects. It should be admitted that there is indeed a series of vases decorated with underworld scenes, and a large quantity of pots decorated with funerary monuments and scenes referring to burial rites (fig. 6.24). ${ }^{145}$ These date predominantly to the last three or four decades of the 4th century BC. In addition to these, there were scenes believed to represent every day life (e.g. women in their boudoir, returning warriors), and themes taken from Greek mythology and Greek drama. ${ }^{146}$ The latter two subjects are, of course, closely interwoven since Greek tragedies almost invariably used themes derived from Greek mythology.

Why did the Tarantine and Metapontine vase painters select these Greek myths for pots that served a mainly non-Greek clientele? First it should be noted that most of the scenes on the red-figured vases do not stem from the handful of myths that played a significant role in Italiote beliefs about afterworld and underworld such as the rebirth myths referring to Orpheus and Dionysus. There is indeed such a variety of myths that the scenes depicted on Italiote Red Figured ceramics are quite sufficient to illustrate a quite detailed handbook on Greek mythology. Some of them are even so obscure that presentday specialists in ancient iconography have difficulties in decoding the scenes. ${ }^{147}$ It is, therefore, highly doubtful whether the prosperous Lucanians or Messapians who were the largest consumers of these wares, were capable of reading and understanding the mythological representations. This suggests that the predominantly non-Greek persons who acquired these pots were not interested in the Greek messages painted on these pots. The red-figured vases were acquired by non-Greeks of southeast Italy because they carried a figurative decoration and because it was the general custom in non-Greek southeast Italy to bury high-ranking persons (especially men) with Corinthian, Attic or early-Italiote figured wares during the preceding 6th and 5th centuries BC. ${ }^{148}$

Painting red-figured vases is relatively time-consuming. By about $360 \mathrm{BC}$ a 'cheaper' variant of red-figured was made at Taras: the so-called Gnathia pottery. ${ }^{149}$ The pots of this class were completely covered with a shiny black gloss. The ornaments were painted on top of the gloss with a white, yellow or dark red paint. The decoration of Gnathia wares is invariably much simpler than that of the red-figured pots. It consists of vines and grapes, branches with ivy leaves, dotted sprays and necklaces which stress the architecture of the pots or frame simple figurative ornaments (e.g. masks, vessels, female heads). Like the more lavishly decorated red-figured pots, Gnathia wares often ended up in tombs (fig. 6.43).

Taras is often believed to have been the main production centre of Gnathia wares. But wasters of Gnathia ware have also turned up at Metapontion ${ }^{150}$ and there are reasons to believe that by the late 4th century BC workshops producing these wares also existed in northern Apulia. ${ }^{151}$ Gnathia pottery, therefore, was made in the same centres in which red-figured ceramics were produced. These too, are likely to have been made in Arpi and Canosa, the large central places of northern Apulia in the late

145 Lohmann 1979.

146 Attic tragedies were especially popular subjects on Italiote pottery of the 4th century BC, see Webster 1967.

147 The scenes painted on the red-figured vases of southern Italy were often the current mythical themes such as the judgement of Paris or elements taken from the Medea story. Unusual subjects were also depicted, for instance, the rape of the Leucippidae, the madness of Lycurgus and the metamorphosis of Callisto.

148 The question still remains how Tarentine and Metapontine potters who did not particularly belong to the happy few of their settlements, could have such a detailed knowledge of Greeks myths or Greek drama.

149 For Gnathia wares, see Forti 1965; Webster 1968; D’Amicis 1996. Gnathia (or 'Gnathian') pottery is named after the non-Greek site of Gnathia in southern Apulia, where large numbers of pots of this class were found during the 1880 s.

150 D’Andria 1975 and 1980.

151 A few Gnathia vase forms occur exclusively in northern Apulia. See, for instance, the burials published in Cassano et al. 1992. 

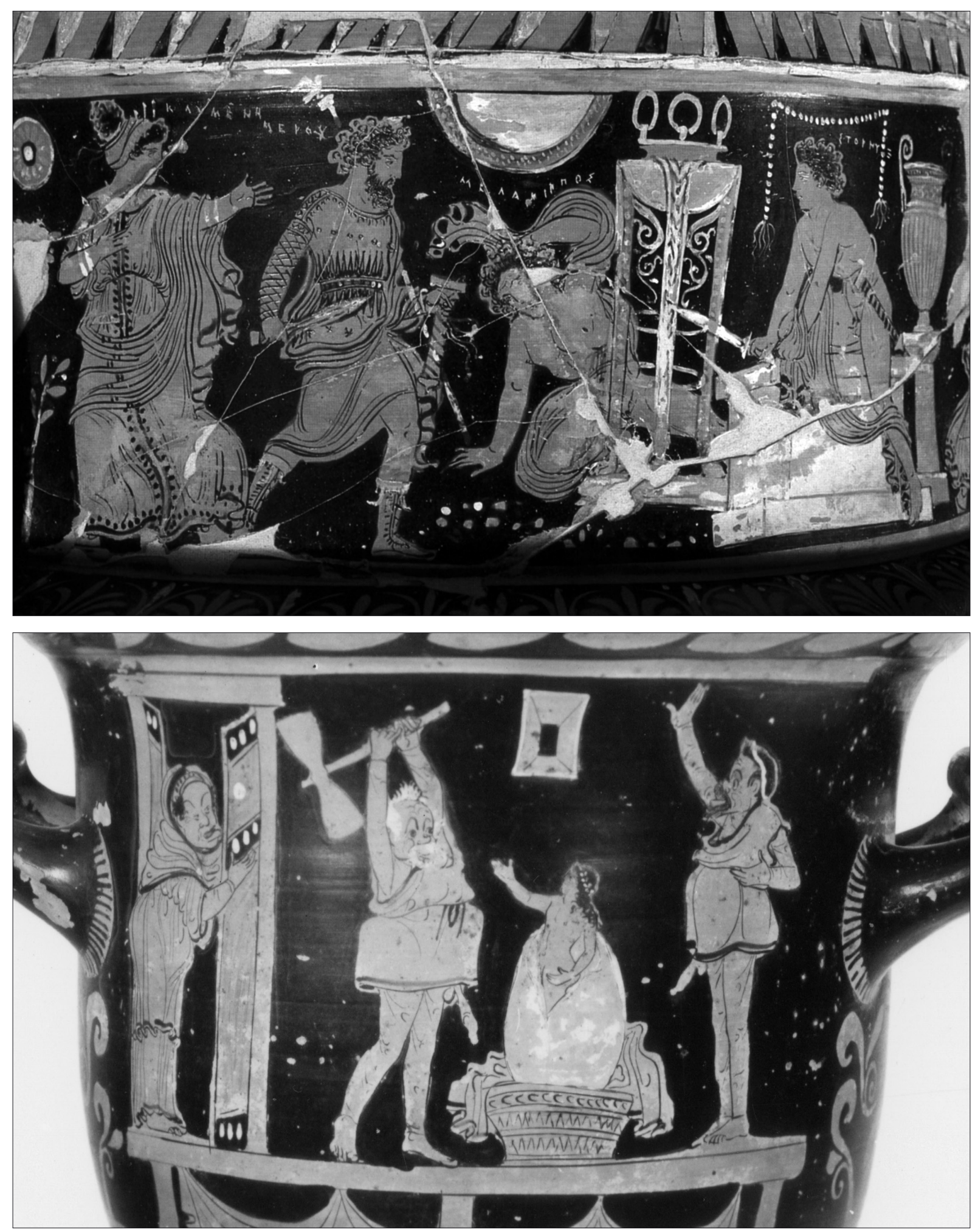

Fig. 6.42. Details of Apulian red-figured wares, 4th century BC. Courtesy Bari Museum. 

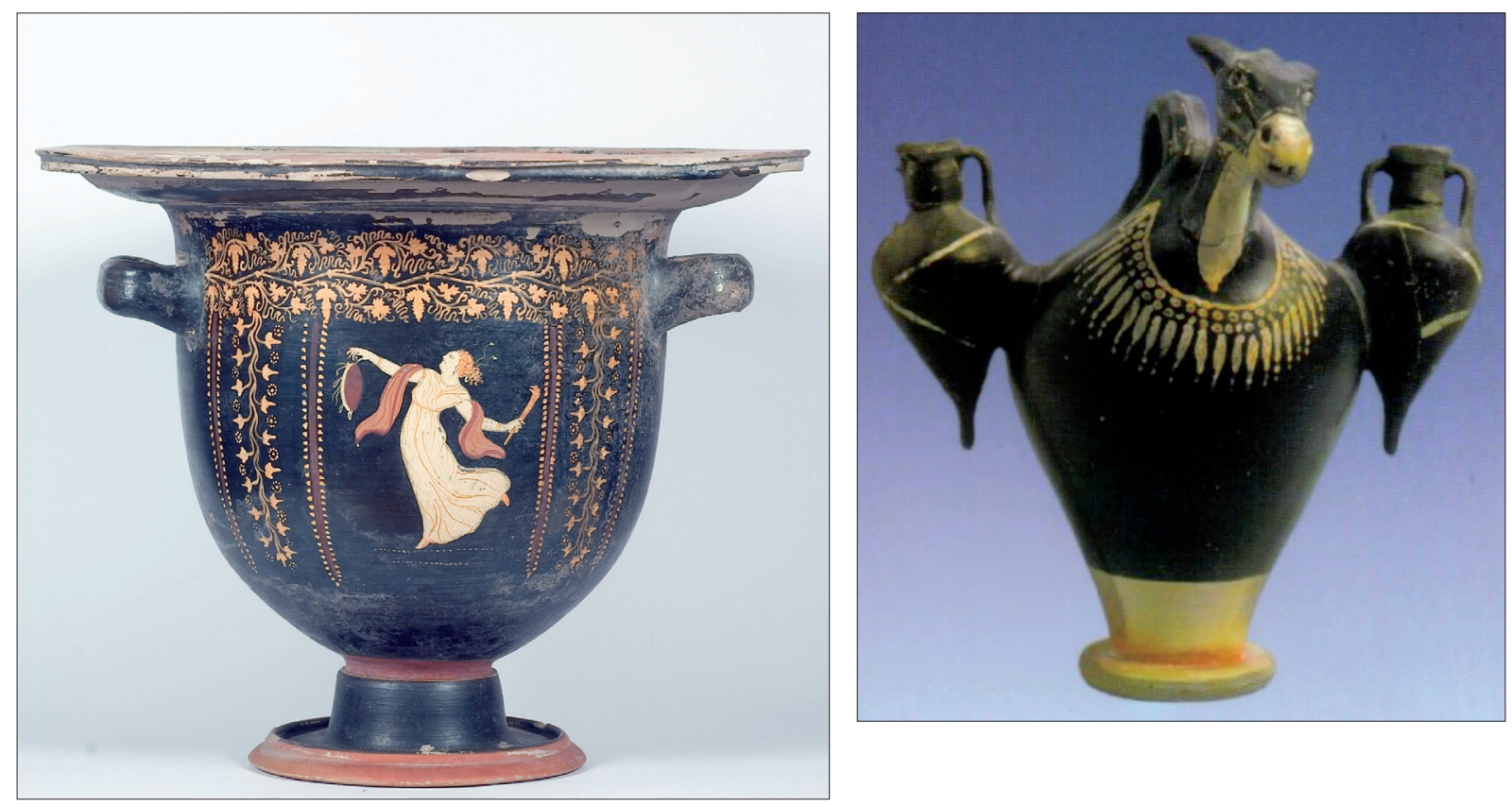

Fig. 6.43. Gnathia wares from Salento burials: (a). bell krater from Rudiae (Taranto fabric), mid- to later 4th century BC; Lecce, Museo Castromediano; (b) mule carrying Graeco-Italic amphorae (Taranto fabric), late 4th/early 3rd century BC; Bari, Archaeological Museum. Courtesy museums of Lecce and Bari.

4th century BC. ${ }^{152}$ On the basis of the kiln refuse of Metapontion it is quite certain that these same workshops produced other classes of pottery such as Black Gloss and Plain and Banded wares. Terracotta statuettes came from the same kilns. As we have seen in the preceding chapter, finger prints on the Metapontion wasters suggest that there was quite an intricate labour division in these workshops involving at least four persons, probably on a full time basis. ${ }^{153}$ In many other settlements workshops with a small workforce and a more limited range of products were active. These produced only Black Gloss pottery, terracotta statuettes and Banded and Plain wares. ${ }^{154}$

Both Taras and Metapontion had a veritable kerameikos consisting of a group of contemporary workshops. Each of these was outside the habitation area and had probably a relatively complex organization of pottery production. ${ }^{156}$ The traces of pottery production at the polis of Herakleia, however, suggest that less complex forms of organization could also be encountered. ${ }^{157}$ These workshops were all situated in polities which were centrally organized states. As at Athens or Corinth the potters of these Italiote poleis are likely to have been independent entrepreneurs who conducted their own business. They had to contend with systems of supply and demand in what was a basically market-oriented economy.

Their colleagues in indigenous settlements worked within the decidedly different social and economic context of tribal systems. As we have seen in the cases of Roccagloriosa in Lucania and Muro Tenente in the Salento peninsula, local clans are likely to have controlled their own territories in and around the settlement areas of these two indigenous centres (see section 6.2). The only information

152 Trendall / Cambitoglou 1982.

153 D’Andria 1997; De Siena et al. 2001.

154 Yntema 1994 (Valesio).

155 In the Canosa area matt-painted pots continued to be produced for funerary purposes till the late 3rd or early 2nd century BC (Late Listata wares; Yntema 1990, 272-286). These ceramics were wheelmade.

156 De Siena et al. 2001, 103-114.

157 Neutsch 1967. 
about the spatial aspects of pottery production in indigenous settlements comes from the urban survey at Muro Tenente (Brindisi area). Here wasters and misfired pottery of the end of the 4th and early 3rd centuries were collected at various spots within the walled area. These were hundreds of meters apart. This suggests that each of the three or four local clans of this Messapian site may have had its own small pottery production unit in the period under discussion. The clan workshop was probably located in the clan territory within the walled settlement area. The context in which the potters of non-Greek southeast Italy functioned, may, therefore, have differed substantially from those of the poleis. Whilst the latter were basically independent entrepreneurs, the former were bound to their clan and its leader.

Although the ceramics of southeast Italy were produced in originally Greek ways with originally Greek types of decoration, it was especially in pottery produced for funerary purposes that native traditions persisted. Traditional features are mainly present in the repertories of forms of the various districts. A closed vessel with unusually tall handles having terracotta wheels is found in the tombs of Messapian women. It is an epigone of an Iron Age form that became popular in the late 8th century BC (see fig. 4.22d). This so-called trozzella survived till well within the 3rd century BC (fig. 6.44). ${ }^{158}$

The 4th-century trozzella is a cultural hybrid since it displays a non-Greek form, but is made in the Greek wheelmade technique with Greek types of ornaments arranged in a traditional native way and painted with a ferroid clayslip according to the Greek custom. Southern Italy indeed produced a most surprising series of such hybrids between the 5th and the 3rd century BC. The most astonishing examples come perhaps from the north-Apulian site of Canosa where traditional features died hard. Here ceramics with a magnificent blend of native and Greek features were made for funerary purposes and deposited in the hypogaea of the wealthy local elite (fig. 6.45). ${ }^{159}$

This cultural hybridization was not confined to ceramics made in non-Greek areas, but also affected pottery workshops in Italiote poleis. Workshops at both Taras and Metapontion, for instance, produced red-figured pots with non-Greek shapes and Greek scenes, with Greek shapes and nonGreek scenes or even with non-Greek shapes and representations of natives (fig. 6.46). This is not as remarkable as it seems, since Attic potters adopted both Etruscan and native Apulian shapes in the late 6th and 5th centuries (see chapter 5.6).

Ceramics were, of course not the only type of artifacts that survived in the archaeological records of southeast Italy. While implements made from wood, leather or cloth are irretrievably lost, metals survived only when they could not be recycled. This observation holds for votive contexts, but it is especially the graves which have supplied metal objects. These of course, were carefully selected for the burials and represent only a fraction of the total range of metal objects produced and used during the period under discusssion. As we have seen above, the graves of native chieftains could contain body armour (fig. 6.29), offensive weaponry, and bronze vessels relating to banqueting, whilst ladies of both Greek and non-Greek elites could be buried with spectaculair personal ornaments made of precious metals (see section 6.3). In the graves of the less privileged metal objects were often restricted to one or two fibulas only.

In the preceding chapter we have seen that new crafts and more complex forms of craft organization developed in the four Greek settlements in southeast Italy during the 6th century BC. These innovations coincided more or less with the genesis of urban centres and a new form of political organization: the polis. In the non-Greek settlements similar changes occurred at about the same time, but on a

158 For trozzellas and their history, see Forti 1972, and 1979; Yntema 1974.

159 These were the Listata wares (Abruzzese 1974; Yntema
1990, 272-286) and the Polychrome wares with plastic decoration (e.g. Van der Wielen-Van Ommeren 1986 and 1992) 


\begin{tabular}{|c|c|c|c|c|c|}
\hline class & fabric & decoration & use & production centres & dating \\
\hline $\begin{array}{l}\text { Apulian and Luca- } \\
\text { nian Red-Figured }\end{array}$ & $\begin{array}{l}\text { wheelmade; light- } \\
\text { coloured clay }\end{array}$ & $\begin{array}{l}\text { background and } \\
\text { details of figured } \\
\text { decoration painted in } \\
\text { black gloss }\end{array}$ & $\begin{array}{l}\text { native burials and } \\
\text { sanctuaries }\end{array}$ & $\begin{array}{l}\text { Taras and Metapon- } \\
\text { tion; } \\
\text { from late 4th cen- } \\
\text { tury probably also in } \\
\text { a few native centres } \\
\text { (Canosa?) }\end{array}$ & $\begin{array}{l}450 / 440 \\
\text { till c. } 300 / 280\end{array}$ \\
\hline Gnathia pottery & $\begin{array}{l}\text { wheelmade; light- } \\
\text { coloured clay, }\end{array}$ & $\begin{array}{l}\text { completely covered } \\
\text { with black gloss; on } \\
\text { top of gloss painted } \\
\text { ornaments in red, yel- } \\
\text { low and white }\end{array}$ & $\begin{array}{l}\text { native burials and } \\
\text { sanctuaries }\end{array}$ & $\begin{array}{l}\text { Taras and Metapon- } \\
\text { tion; } \\
\text { from late 4th cen- } \\
\text { tury probably also in } \\
\text { a few native centres } \\
\text { (Canosa?) }\end{array}$ & $\begin{array}{l}360 / 350 \\
\text { till c. } 225 / 200\end{array}$ \\
\hline $\begin{array}{l}\text { Apulian-Lucanian } \\
\text { Black Gloss wares }\end{array}$ & $\begin{array}{l}\text { wheelmade; light- } \\
\text { coloured clay, }\end{array}$ & $\begin{array}{l}\text { completely covered } \\
\text { with black gloss }\end{array}$ & $\begin{array}{l}\text { Greek and native } \\
\text { households, buri- } \\
\text { als, sanctuaries }\end{array}$ & $\begin{array}{l}\text { nearly every settle- } \\
\text { ment with a few thou- } \\
\text { sand inhabitants }\end{array}$ & $\begin{array}{l}480 / 470 \text { till } c . \\
125 / 100\end{array}$ \\
\hline $\begin{array}{l}\text { Banded and Plain } \\
\text { wares }\end{array}$ & $\begin{array}{l}\text { wheelmade; light- } \\
\text { coloured clay; }\end{array}$ & $\begin{array}{l}\text { Undecorated (Plain } \\
\text { wares) or deco- } \\
\text { rated with dark brown } \\
\text { bands and (sparsely) } \\
\text { vegetal ornaments }\end{array}$ & $\begin{array}{l}\text { Greek and native } \\
\text { households, buri- } \\
\text { als, sanctuaries }\end{array}$ & $\begin{array}{l}\text { nearly every settle- } \\
\text { ment with a few thou- } \\
\text { sand inhabitants }\end{array}$ & $\begin{array}{l}\text { later 6th } \\
\text { century till c. } \\
150 / 125 B C\end{array}$ \\
\hline $\begin{array}{l}\text { coarse cooking } \\
\text { wares }\end{array}$ & $\begin{array}{l}\text { wheelmade; dark- } \\
\text { coloured surface, } \\
\text { heavily tempered clay }\end{array}$ & undecorated & $\begin{array}{l}\text { Greek and native } \\
\text { households }\end{array}$ & unknown & \\
\hline terracottas & $\begin{array}{l}\text { mouldmade, light- } \\
\text { coloured clay }\end{array}$ & painted & $\begin{array}{l}\text { Greek and native } \\
\text { burials and sanc- } \\
\text { tuaries }\end{array}$ & $\begin{array}{l}\text { nearly every settle- } \\
\text { ment with a few thou- } \\
\text { sand inhabitants }\end{array}$ & $\begin{array}{l}\text { From the late } \\
\text { 7th century } \\
\text { onward }\end{array}$ \\
\hline matt-painted wares & $\begin{array}{l}\text { handmade, light- } \\
\text { coloured clay }\end{array}$ & manganese paint & $\begin{array}{l}\text { burials in northern } \\
\text { Apulia }\end{array}$ & District around Canosa & $\begin{array}{l}\text { From Bronze } \\
\text { Age till c. } 300 \\
\mathrm{BC}^{155}\end{array}$ \\
\hline impasto wares & $\begin{array}{l}\text { handmade or wheel- } \\
\text { made }\end{array}$ & plastic decoration & Native households & $\begin{array}{l}\text { non-Greek areas of } \\
\text { Apulia }\end{array}$ & $\begin{array}{l}\text { from Bronze } \\
\text { Age till c. } \\
300 \mathrm{BC}\end{array}$ \\
\hline
\end{tabular}

Table 6.1. Survey of the pottery classes made and used in southeast Italy during the later 4th century BC.

much smaller scale (mainly pottery production and building techniques). In the later 4th century BC, however, the material culture of the non-Greeks hardly differed from that of the south-Italian Greeks. The various types of craft and the organization of production in the non-Greek areas hardly differed from those of the Greek towns, although their political organization continued to have decidedly tribal features. Initially luxury items were exclusively produced in regional centres (e.g. the goldsmiths of Taras), but by the last third of the 4th century even technically complex products such as large redfigured funerary pots were made in indigenous settlements of southeast Italy. ${ }^{160}$

The archaeological evidence suggests a substantial homogenization of material culture over large parts of southeast Italy. The pots that were used in Messapian or Lucanian households were not fundamentally different from the pots used in the often very similar Greek houses of Taras or Metapontion. Most Greeks, Lucanians and Messapians drank the same wine from the same black gloss skyphos and

160 As for Italiote Red-Figured pottery, the workshops of the Apulian Baltimore Painter and White Saccos Painter are likely to have been located in northern Apulia (Trendall / Cambitoglou 1982) while the workshop of the Lucanian Roccanova Painter is believed to have operated in the uplands of Lucania (Trendall 1967). 


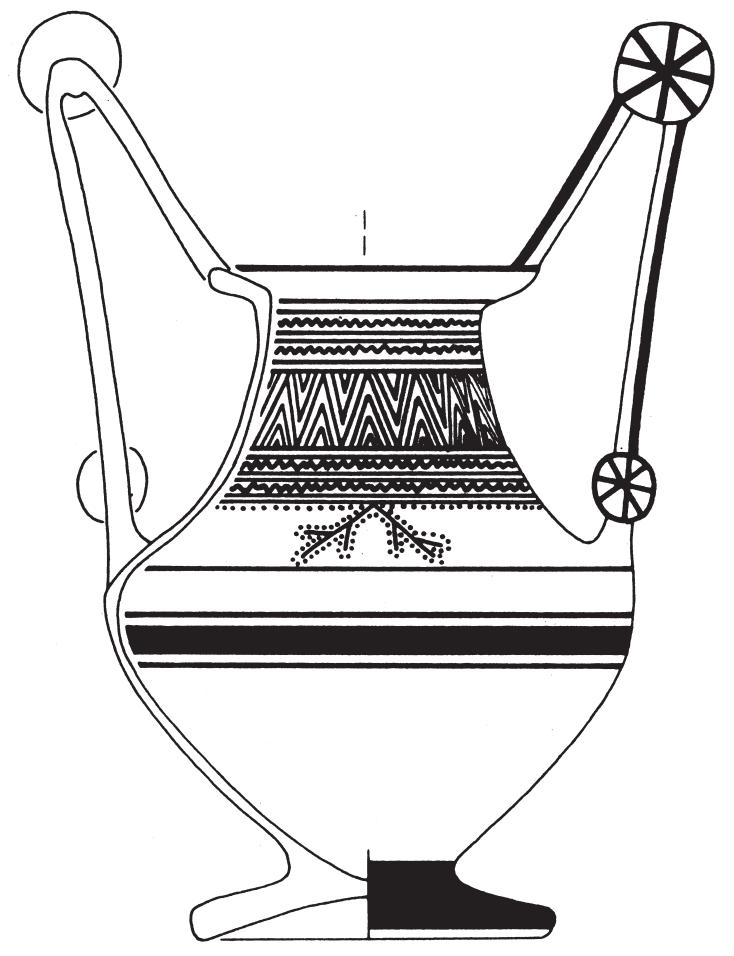

Fig. 6.44. Trozzella with Gnathia-like dotted spray decoration (Salento district, south Apulia). Late 4th/ early 3rd century BC.

prepared very similar meals in almost identical cooking pots (fig. 6.41).

The evidence suggests that there were both a substantial number and a great variety of craftsmen in the later 4th and earlier 3rd century BC. These were present not only in the four Greek polities on the Gulf of Taranto, but also in the tribal settlements of southeast Italy. They exerted specialist labour and were involved in many different tasks. In the sector of architecture people extracted and worked blocks of stone, constructed complex fortification systems, public buildings and houses, produced rooftiles, mudbrick and architectural terracottas. In the field of ceramics there were potters and coroplasts who made the pots and pans, the terracotta statuettes and the loomweights for domestic, funerary and votive purposes. Recycling prevents us from getting a good insight into the use of metals and the role of the artisans that produced them. There must have been blacksmiths in many settlements. They produced agricultural implements of bronze and iron (e.g. ploughs, ards, hoes), weaponry (e.g. spears, javelins, arrow heads) and personal ornaments (e.g. rings, fibulas). Specialized gold- and silversmiths may have been active in one or two settlements of southeast Italy only. The specialists that worked wood, leather and fine textiles elude us completely, because these materials simply do not survive. Their presence may be suspected on the strength of passages of ancient Greek authors on the early Hellenistic Mediterranean.

\subsection{E C O N O M A N E T T ER A L C O N T A T S}

The unprecedented prosperity and wealth of 4th-3rd century BC southeast Italy suggest a booming economy for the period under discussion. Since the area is notoriously poor in raw materials such as metals, we may actually ask for the source of its wealth. The basis of the general prosperity of southeast Italy in the 4th and 3rd centuries BC can probably be found in (1) the excellent qualities of the soils, (2) specialization in agriculture and (3) intensifying trade networks in the Mediterranean. This meant that commodities produced in large quantities as a result of relatively intensive and increasingly specialized agriculture and stock raising practices could be exchanged by transporting them over large distances and selling them at far away markets.

The indications of the influence exerted by these three factors are many. The qualities of the soils (factor 1) are evident. The large plains which can be found in the coastal zone on the Gulf of Taranto (e.g. the plain of Sybaris, the flatlands around Metapontion), in the Brindisi district of southern Apulia and in northern Apulia (the Tavoliere), were admirably suited for the production of cereals and could serve as pastures when they lay fallow. The ears of corn depicted on the Metapontine coins indicate 

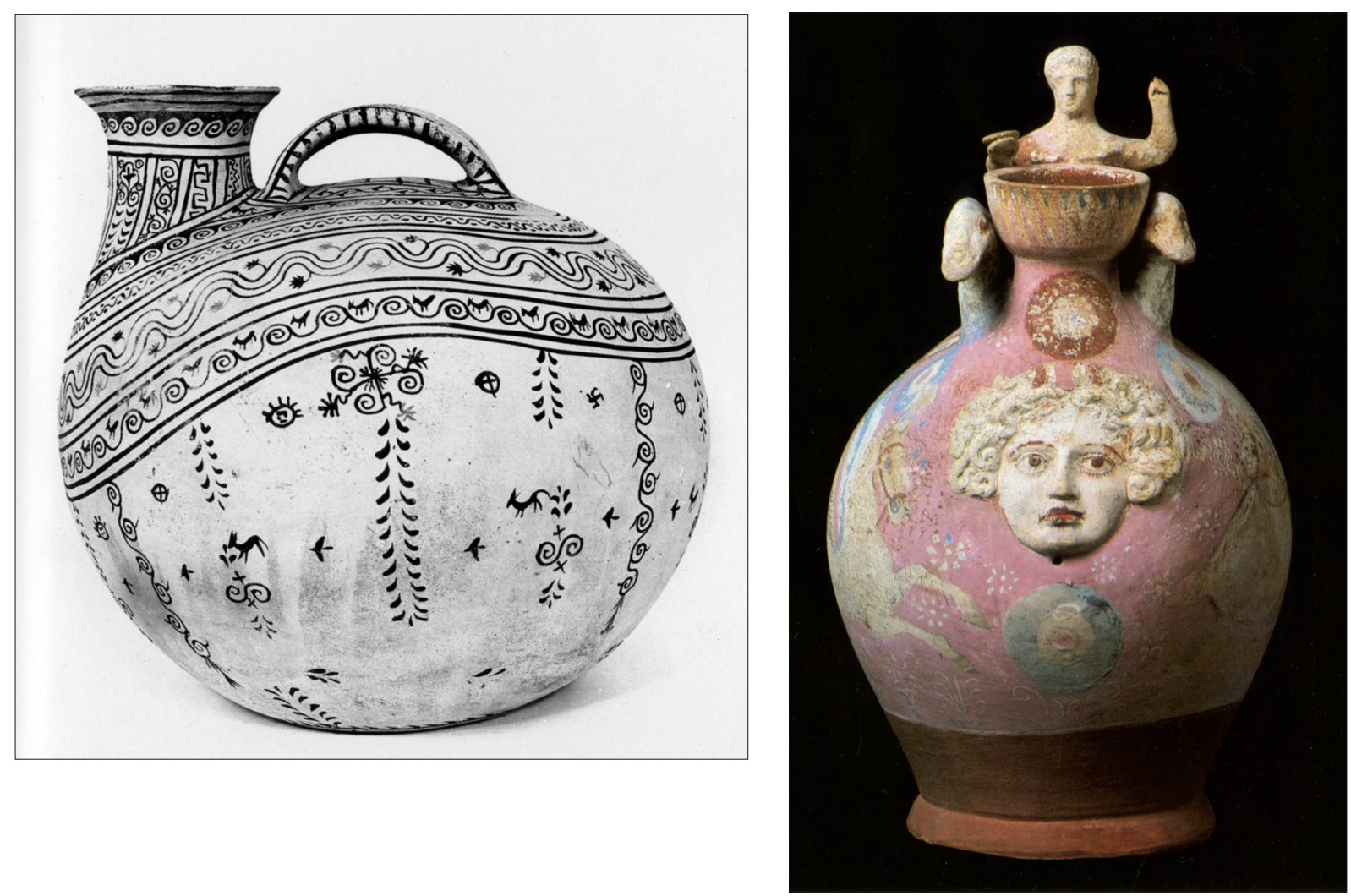

Fig. 6.45. Funerary wares produced at Canosa (north-Apulia) during the late 4th and 3rd centuries: a. handmade traditional form (askos) with Grecian ornaments (Listata II), late 4th century BC; b. wheelmade traditional form (askos) covered with Greek terracotta statuettes and painted in pink and blue (Canosan Polychrome with plastic ornaments), 3rd century BC. Photos courtesy Bari Museum.

that the inhabitants of this town took ample advantage of this opportunity. The sloping hills surrounding these plains were attractive spots for viticulture (e.g. the hills around the Taras and Sybaris plains), whilst the limestone areas with thin cover offered excellent opportunities for the cultivation of olives (in central Apulia and the southern part of the Salento peninsula). The mountainous uplands of Basilicata and the Murge massif of central Apulia could serve as summer pastures for flocks of sheep. The forests which continued to occur here as well as in several other parts of southeast Italy in the time under discussion, supplied timber (e.g. for ship building) and were forage areas for herds of swine.

Specialization in agriculture and stock raising (factor 2) can be deduced from various sources. One of the important indications is the exponential increase in rural farmsteads. Field surveys in the area of Metapontion have demonstrated that whilst the creation of a rural landscape took place in the 6th century BC, the countryside was most intensely occupied and exploited during the later 4th and earlier 3rd centuries BC). ${ }^{161}$ It was during the early Hellenistic period that the number of farmsteads was at its height here. Farmsteads and hamlets of approximaltely the same date have been reported from the areas surrounding Taras and Herakleia. Moreover, as we have seen above (section 6.2) the creation of a cultivated and inhabited countryside in non-Greek territories happened at about the very same time. This means that within a few decades large areas were reclaimed for cultivation and that the agricultural output of southeast Italy increased exponentially.

161 Carter 1998b, 2001, 2006. 


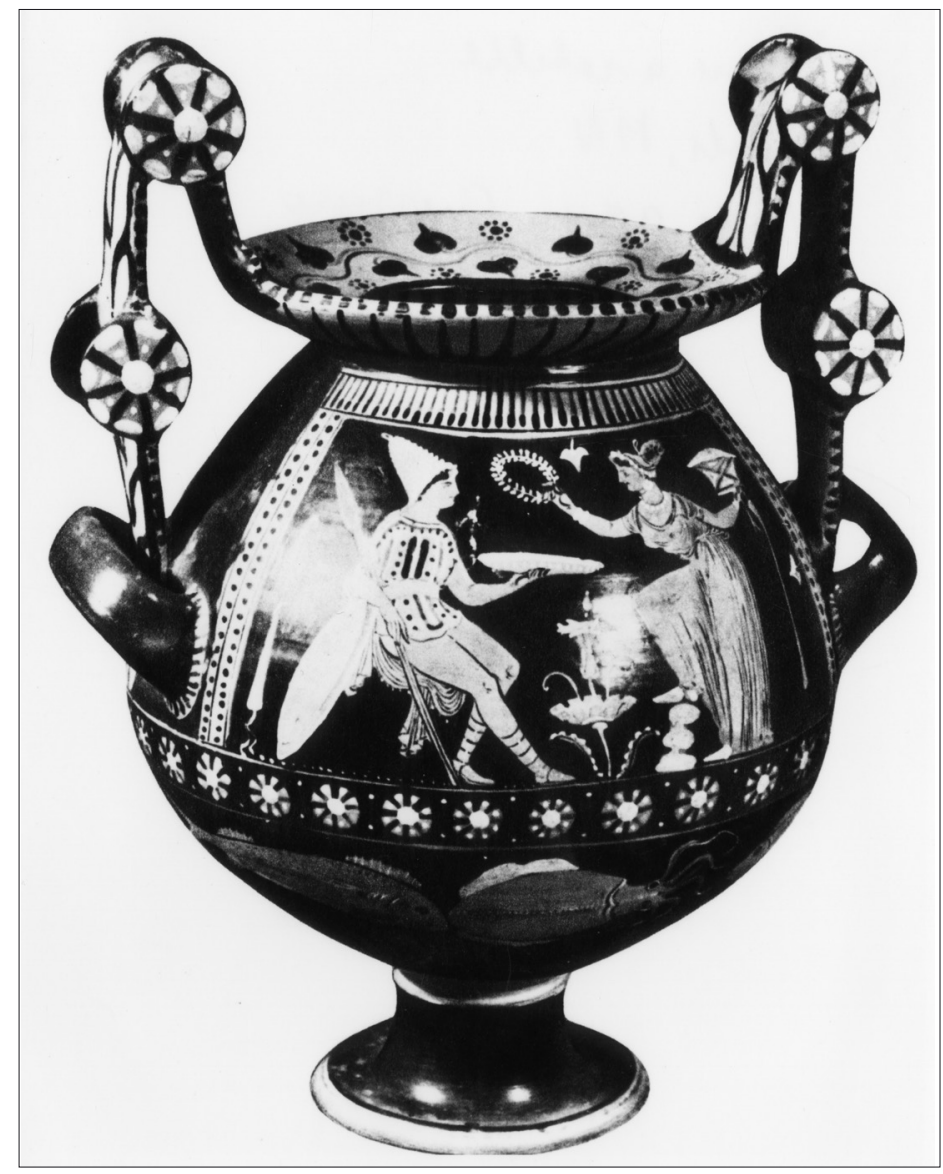

Fig. 6.46. Apulian red-figured 'nestoris' with representation of non-Greeks. Naples, Museo Archeologico.

Good evidence for drastic environmental change is usually found in pollen cores. The palynological data stemming from the Metapontion area are the only evidence of this type published hitherto. ${ }^{162}$ The poor data available at present confirm the picture suggested by the field surveys and indicate that substantial changes occurred in the vegetation. But whilst the palynological data are scarce, there is good evidence regarding stock raising consisting of bone samples from various sites. Generally speaking, these show a decrease in the percentages of cattle, while the percentages of both sheep/goat and pig display a slight increase. When we look at the mortality data of the animal husbandry, it appears that while sheep/goats were killed at a relatively early age during the Iron Age and Archaic-Classical periods (between one and two years), they often lived as long as three to four years in the Early Hellenistic Age (fig. 6.47). This suggests that they were no longer exclusively kept for their meat, but that the things they produced during those additional two to four years became important: wool and milk/cheese. ${ }^{163}$

We have no information about the importance of the cheeses of southeast Italy in the period under discussion. The fine wools of Taras and Canusium (Canosa), however, had a wide renown in the ancient world. They were so special indeed that the general indication for fine woollen clothing in ancient times was tarantidia. ${ }^{164}$ The thousands of loomweights that turn up during excavations and surveys indicate that woolen cloths were made in many households of the Greek and non-Greek settlements. Ancient written sources regarding the Hellenistic and early-Roman ages also inform us on the good qualities of the wines, olives and olive oil of southeast Italy. ${ }^{165}$ Though we cannot always be certain that these passages of ancient authors are really relevant to the 100 to 150 years discussed in this chapter, the archaeological evidence suggests that the products of the rural and urban farmsteads could be transported over considerable distances. From the late 4th century onward southeast Italy produced a substantial surplus of specialized articles that derived from the cultivated fields and the roaming flocks.

\footnotetext{
162 The soils of southeast Italyare badly suited for the preservation of pollen.

163 Veenman 2002.
}

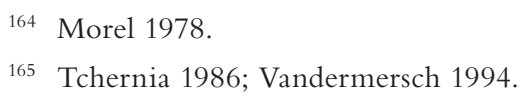


Amphorae confirm the picture of large-scale agricultural production and overseas markets. Though the earliest amphorae produced in southeast Italy made their appearance in the 6th century, ${ }^{166}$ the output of such transport vessels increased enormously from the late 4th century onward, i.e. at the same time as the intensification of farming in both Greek and non-Greek polities. The new type of container vessel that made its appearance at this particular moment was the so-called Graeco-Italic amphora (fig. 6.48) of which the study is still in its infancy. ${ }^{167}$ They were especially common in the 3 rd and early 2 nd centuries.

Other tracers of long distance contacts between southern Italy and other parts of the Mediterranean are the fine wares. Whilst only small quantities of the predominantly 4 th-century red-figured wares of Taras and Metapontion traveled overseas, it was especially 3rd-century Gnathia pottery that had a wide distribution. These overpainted wares are found in some numbers on the east coast of the Strait of Otranto (e.g. Corfu, Buthroton), both shores of the central Adriatic area (Dalmatia, Picenum), but very considerable numbers of Gnatia pots pots ended up at sites of the eastern Mediterranean. Whilst Athens received only a few pieces of these ceramics, ${ }^{168}$ it was especially at the important trade centres of the Hellenistic Age such as Rhodes, Knossos, Alexandria and Berenike-Benghazi that substantial quantities of Gnathia were found. ${ }^{169}$ A similar overseas distribution of 3rd century Apulian Black Gloss wares may be surmised, but these have often not been recognized in the ceramic samples excavated at eastern Mediterranean sites. ${ }^{170}$

The limited number of tracers indicating the long distance contacts of southeast Italy suggests that the trade networks in which this area participated spanned much of the Adriatic Sea (e.g. Issa, Ancona), the southern Aegean (e.g. Rhodes, Crete) and Ptolemaic Egypt (Alexandria, Berenice). A thorough investigation into this matter may well reveal that these contacts were quite intense and involved more areas than can be surmised at present. ${ }^{171}$ From the evidence it seems to emerge that southeast Italy and especially Taras, its most important port, played a significant role in the contacts between Italy and the eastern Mediterranean. The polis of Taras may indeed have been pivotal in contacts between the eastern and western Mediterranean: even the Spanish eastcoast got its share of Gnathia wares. ${ }^{172}$ The same role is suggested by the ancient written sources. ${ }^{173}$

The evidence for such contacts uncovered hitherto regards much of the 3rd century BC. This is interesting, since it demonstrates that the Roman conquest of Taras in 272 did not turn the hegemon of the Italiote league into a quiet and impoverished backwater on the fringes of a hardly Romanizing Italy. After the Roman conquest Taras continued to be an important element in the Mediterranean trade networks. The image of continuing prosperity also emerges from the burial grounds of Taras. ${ }^{174}$ To this Tarantine evidence can be added the strong continuity (or even growth) of rural settlement in all parts of southeast Italy. ${ }^{175}$ Together these data suggest that the town (and with it large parts of south-

166 At least a part of the so-called Corinthian B amphorae were made in southeast Italy (Sourisseau 2011).

167 Vandermersch 1994.

168 Rotroff 1997.

169 Green 1979.

170 There appears to be a good sample of these Apulian Black gloss wares (mainly from Taranto, it seems) among the well diagnosed and well-published fine wares of Sidi Khrebish/Benghazi/Berenice (see Kenrick 1985).

171 There might well be generous samples of 3rd-century Apulian Black Gloss wares at, for instance, Delos, Rhodes, Crete and coastal Egypt; more profound research into the distribution of Graeco-Italic amphorae, moreover, may also contribute to a more complete picture of the economic networks of southeast Italy, and more specifically Taras.

172 For Gnathia wares from Spain, see, for instance, Pérez Ballester 2002, 33-39 (e.g. some 15 to 20 mostly ribbed specimens from Cartagena).

173 Marasco 1988.

174 See exhibition catalogue Ori di Taranto and Graepler 1997.

175 For Salento, see, for instance, Boersma et al. 1991, Yntema 1993a; for northern Apulia, see Volpe 1990; for Lucania, see Gualtieri / Fracchia 2001. 
east Italy) continued to florish during a large part of the 3rd century BC. Therefore, the the Roman victories over Taras, the Lucanians and the Messapians (272/265) had no dramatic consequences for the economy of the region. The Roman policy towards southeat Italy was one of laissez-faire, as long as the taxes were collected and troops were supplied at Rome's request. Therefore, the decisive Roman victories of the years 272 (Taras), 267/266 (Messapians) and 266/265 (Lucanians) cannot be viewed as the first step towards the poor Roman Mezzogiorno as has often been assumed: the cliché image of large, slave run latifundia and widespread pastoralism that is believed to have been characteristic of southern Italy in Roman times.

The preceding sections have implicitly suggested that there was a link between the economies of Taras and other poleis of southeast Italy with the economies of territories inhabited by non-Greek speakers such as Lucanians and Messapians. This link was probably very close indeed. The thousands of intricately decorated pots that ended up in the burial grounds of non-Greek populations (Apulian and Lucanian Red-Figured, and Gnathia pottery) are tracers of the intense contacts between the Italiote Greeks and neighbouring tribal groups. Thourioi, Herakleia and Metapontion controlled the coastal strip of river basins that were inhabited by groups of Lucanian stock. When surplusses produced by the inland Lucanians had to be transported to overseas markets, these had to pass through Greek states. It is therefore plausible to assume that there were agreements or even treaties regulating exchanges between the Greek towns and their indigenous neighbours. These were doubtlessly profitable to both parties. These close economic ties may well have turned the inland parts of river basins that were inhabited by indigenous groups, into the hinterland of the Greek polity situated at the river mouth. In economic respects Thourioi, Herakleia and Metapontion may have become central places for both Lucanian groups and people living within their own territories. In these urban settlements surpluses of both Greek and native territories were collected for overseas transport.

Of course, tribal groups of present-day Apulia could market their own surplusses since some of these must have controlled considerable stretches of the coastline. In central and southern Apulia there was a series of small coastal settlements (some of which had Bronze Age origins). Since the 6th century $\mathrm{BC}$ these were paired with much larger inland settlements between 4 and $10 \mathrm{~km}$ from the coast. Each of them probably controlled one of these ports. ${ }^{176}$ The small inlets were meeting points where Greek sailors and Italic tribesmen exchanged goods on a limited scale. ${ }^{177}$ This system of 'paired' settlements continued to exist into the 3rd century BC (fig. 6.49). The Italiote Greeks, however, had a distinct advantage over their non-Greek neighbours. Whilst the latter were basically newcomers in the Mediterranean trade systems, Tarantines and other Italiotai had participated in these networks since the Iron Age. Therefore, they had a much better insight into the various regional exchange systems and knew where specific articles were highly prized or urgently needed. It seems therefore, plausible to assume that the Greek poleis of southeast Italy often functioned as intermediaries between the tribal polities and the overseas markets and packed and shipped both their own surplusses and those of their native hinterlands. Taras, because of its dominant political position, its outstanding wealth and its excellent harbour may well have had a special role in southeast Italy. It was doubtlessly the most important port.

176 D’Andria 1976; Yntema 1982b.

177 The substantial lagunal settlements of Siponto and Salapia in northern Apulia were never ports of call in Greek trade networks. These played an important part in the contacts between northern Apulia and Istria/ Damatia between the 8 th and the early 5 th century BC (see chapter 4). In the 4th or early 3rd century these became dependent on (or in any case closely linked with) the large and dominant inland settlements of Arpi (paired with Siponto) and Canosa (paired with Salapia). In the 2 nd and 1 st centuries BC (and again in late-Roman times) Siponto exported corn (passages in both Livy and Strabo) whereas Salapia may well have produced salt. 

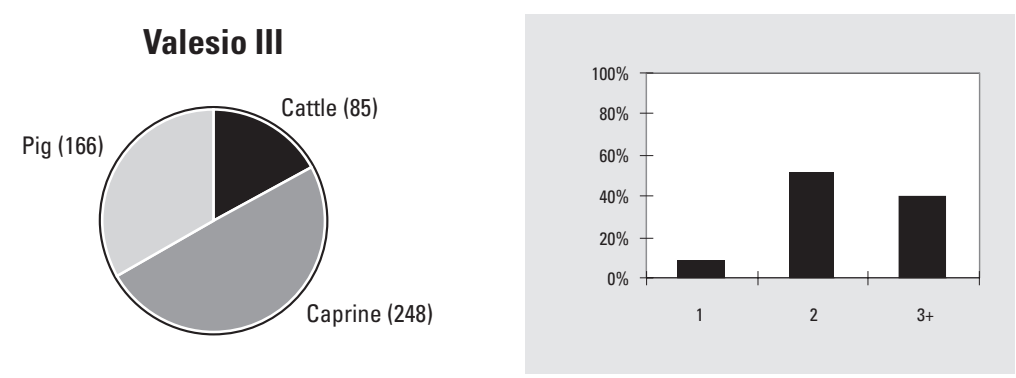

\section{Monte Irsi II}

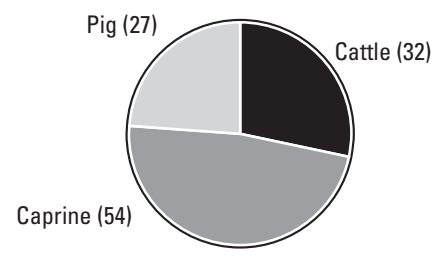

Fig. 6.47. Percentages of household animals and culling ages of sheep/goats, 4th-3rd century BC; after Veenman 2002.

It may have functioned as a staple for the areas surrounding the Gulf of Taranto and a starting point for many ships transporting regional products of southeast Italy to the eastern Mediterranean.

There is little information on the type of products exchanged with overseas areas. Wine and olive oil must have been among these, since the Graeco-Italic amphorae could contain both. We can make educated guesses for other products by looking at the character of the soils and the micro-climates and by extrapolating written sources of slightly more recent times. These sources together suggest that southeast Italy may well have produced considerable surpluses of pork, cheese, wool and cereals. Since snails of the species murex purpurea are common on the Gulf of Manfredonia (northern Apulia) and in the seas near Taranto, purple dye could also have been among the desirable articles of southeast Italy. ${ }^{178}$

In addition to long distance trade there must have been exchanges between neighbouring settlements and regions within southeast Italy. We have seen the case of the Apulian and Lucanian RedFigured wares that traveled from Taras and Metapontion to non-Greek districts. Internal exchange must also have brought olive oil to the uplands of Lucania where the olive trees could not survive the harsh winter of the mountain climate, and limestone to Metapontion situated on alluvial soils. Metals such as bronze and iron - only present in limited quantities in northern Calabria, but common in Etruria and the eastern Hallstatt province around Ljubeljana - must have circulated in the exchange circuits of southeast Italy.

In the 3rd century BC the first steps were set on the path of monetization of southeast Italy. Though the first silver staters were struck here as early as the late 6th century BC, these could be used for large transactions only. Southeast Italy was comparatively late in minting small denominations for everyday transactions. It was not until the middle of the 3rd century BC that small silver coins were minted in the Greek poleis. At about the same time the first issues of bronze coins make their appearance in Metapontion (c. $250 \mathrm{BC}$ ). The first bronze coins of Taras are dated to the very end of the period discussed here. ${ }^{179}$ 


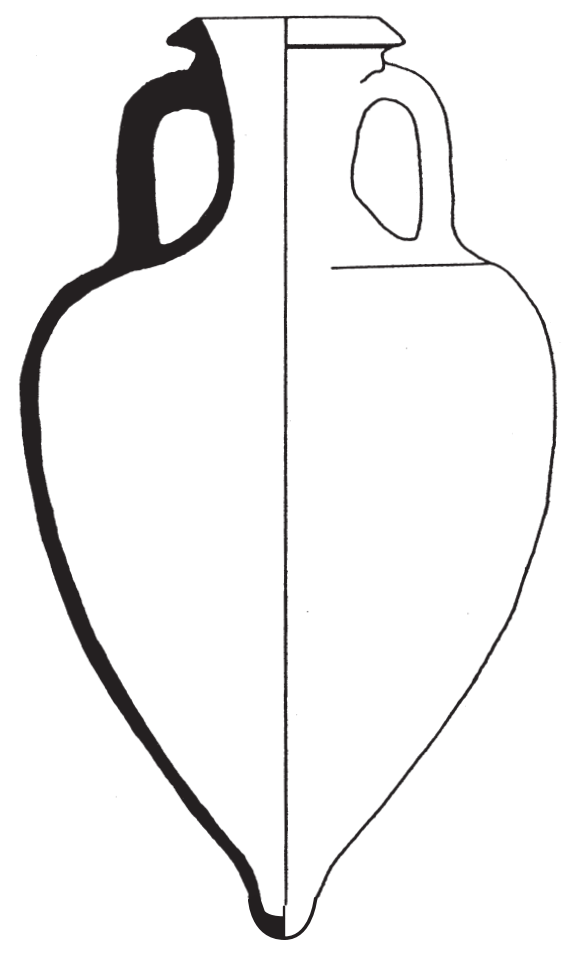

Fig. 6.48. Graeco-Italic amphora from Valesio (Brindisi), contents 42 lt, late 3 th/early 2 nd century BC.

In the late 4th (?) and 3rd centuries, moreover, systematic minting of coins was no longer confined to the Greek polities. ${ }^{180}$ Non-Greek emissions were minted in all regions of southeast Italy. Here, however, a divide can be noted between Apulia on the one hand and Lucania and Calabria on the other hand. Whilst in the latter two regions 'native' emissions were exclusively made by the large tribal confederacies of the Lucanians and the Brettians, ${ }^{181}$ coins were minted by a considerable series of non-Greek settlements of Apulia. Among these were both town-like, walled settlement of central and southern Apulia and the gradually condensing, originally dispersed settlements of the north-Apulian groups. Some 15 Apulian settlements issued coins carrying Greek legends like KAN $\Upsilon \Sigma I N \Omega N$ ('of the people of Kanusion'; Canosa, northApulia), KAI $\Lambda \mathrm{IN} \Omega \mathrm{N}$ ('of the people of Kailia'; Ceglie del Campo, central Apulia), or NEPETIN $\Omega N$ ('of the people of Nereton'; Nardò, south-Apulia). The vast majority of these emissions were in bronze; only six non-Greek settlements minted both silver and bronze. ${ }^{182}$ Their legends and their weights suggest that these native emissions of the late 4th (?) and much of the 3rd century BC were primarily inspired by Greek monetary systems. This is not really surprising, since Greek and non-Greek economies of southeast Italy were so closely interlinked in the period under discussion. Some of these issues are so rare that they must have had only symbolic value.

In economic respect southeast Italy presents a highly dynamic picture in the 4th and 3rd centuries BC. Whilst the sudden spurt made by the Greek poleis in the 6th century had somewhat distant echoes in the non-Greek territories (see chapter 5), both Greek and non-Greek districts displayed the same astonishing economic growth from the later 4th century onward. There is reason to assume that the Greek and non-Greek economies were closely interlinked. Greek towns became economic foci for both their own chörai and adjoining indigenous districts. Wealthy Taras with its magnificent harbour may well have become the economic centre par excellence of southeast Italy.

The increased prosperity had its basis in the drastic innovations in the rural economy of the area. From about 340/330 BC onward agrarian landscapes were created or reorganized on an unprecedented scale. The second innovation was that old and new agricultural plots were exploited more intensely than in any preceding period of southeast Italy's history. In this way very considerable surpluses were generated. A third decisive innovation was the addition of agricultural specialization to the traditional, basically subsistence farming methods in the non-Greek districts, a step the Greek polities of southeast Italy had made in the course of the 6th century BC. This tied in nicely with almost pan-Mediterranean developments that foreshadowed the regional specializations in the Roman Empire.

180 Before the late 4th century BC coins were rarely minted in non-Greek polities. A handful of 5th century silver coins is currently assigned to the settlement of Valesio in northern Salento (see fig. ${ }^{\star} \star \star$ )

\footnotetext{
181 Stazio 1972.

182 Siciliano 1991, Stazio 1992.
} 
The majority of these surplus products are likely to have reached overseas areas. The ceramics that serve as tracers for these contacts, suggest that the central Adriatic (Picenum, Dalmatia), but especially the eastern Mediterranean (Delos, Rhodes, Crete, Ptolemaic Egypt) were the markets where products from southeast Italy were consumed. This intensified participation in the Mediterranean exchange networks generated a very considerable prosperity which was no longer confined to the local elites. It spread over larger groups of the various regional societies which may have contained both farmers and craftsmen. The newly won prosperity was expressed, among other things, in an unprecedented wealth of material culture which can be traced in sanctuaries, burials, private dwellings and public architecture.

As a result of these changes the complexity of the economies of southeast Italy increased enormously. This all happened within a few decades. Coins were indeed minted on a larger scale. This was done now by both Greek towns and indigenous polities. This rapidly increasing economic complexity, however, did not result in an equally rapid monetization. The use of bronze or small silver coins commonly exchanged in minor transactions did not gain momentum before the last decades of the 3rd century BC.

\subsection{S U M M A R Y}

The period covering the late 4th and early 3rd centuries was a time of very substantial demographic growth and very drastic innovations. The changes affected both the towns which saw themselves as Greek states and the non-Greek polities with various types of tribal structures. In the Greek states oligarchic and more or less democratic forms of government alternated. These poleis were initially rather loosely united in the Italiote league. Being Italiotai, however, did not mean much to Greeks of southeast Italy. They were and continued to be Tarantines, Metapontines, etc. But in the course of the 4th century the polis of Taras became increasingly dominant. The dynamic leadership of the statesmanphilosopher Archytas in the 360s may have contributed to this new role. The town became not only the league's unchallenged hegemon. In fact, Tarantine policy became league policy and other 'member states' grudgingly accepted the dominance of mighty Taras.

Among the non-Greek polities similar clustering of formerly separate and independent groups can be observed. We have seen that the first signs of such developments date to the second half of the 5th century BC. It was probably not before the later 4th century that more or less federal forms of organization were institutionalized. Such political federations are exemplified by the large, tribal confederacies of the Brettians (north Calabria) and Lucanians (Basilicata and southern Campania). Perhaps the Calabri and Sallentini, i.e. the Messapian groups of southern Apulia, had comparable social structures. These confederacies displayed a relatively loose form of central authority, since the major settlements and their respective territories within these confederacies enjoyed a semi-independent status. In principle Lucanian sub-tribal units were bound to the Nomen Lucanum and consensus decisions taken by the central authority of the Lucanians (possibly a tribal council headed by the supreme leader in which the most important sub-tribal chiefs participated). Sub-tribes, however, could act on their own initiative when there was no 'pan-Lucanian' decision or policy on a particular matter. The Roman contacts with Lucanians between 320 and 270 suggest, for instance, that sub-tribal units of the confederacy could conclude treaties with non-Lucanian polities.

The Lucanian and Brettian settlements were governed by elites consisting of the leaders of the local clans. These enhanced their status by martial prowess in battle, by living in spacious dwellings with large dining rooms with all the accoutrements that befitted their status, and by means of a special role in the rituals performed in the local sanctuary (ritual dinners among these). The various local elites, moreover, convened to the tribal sanctuary (e.g. Rossano di Vaglio, Oria) in order to display both their 


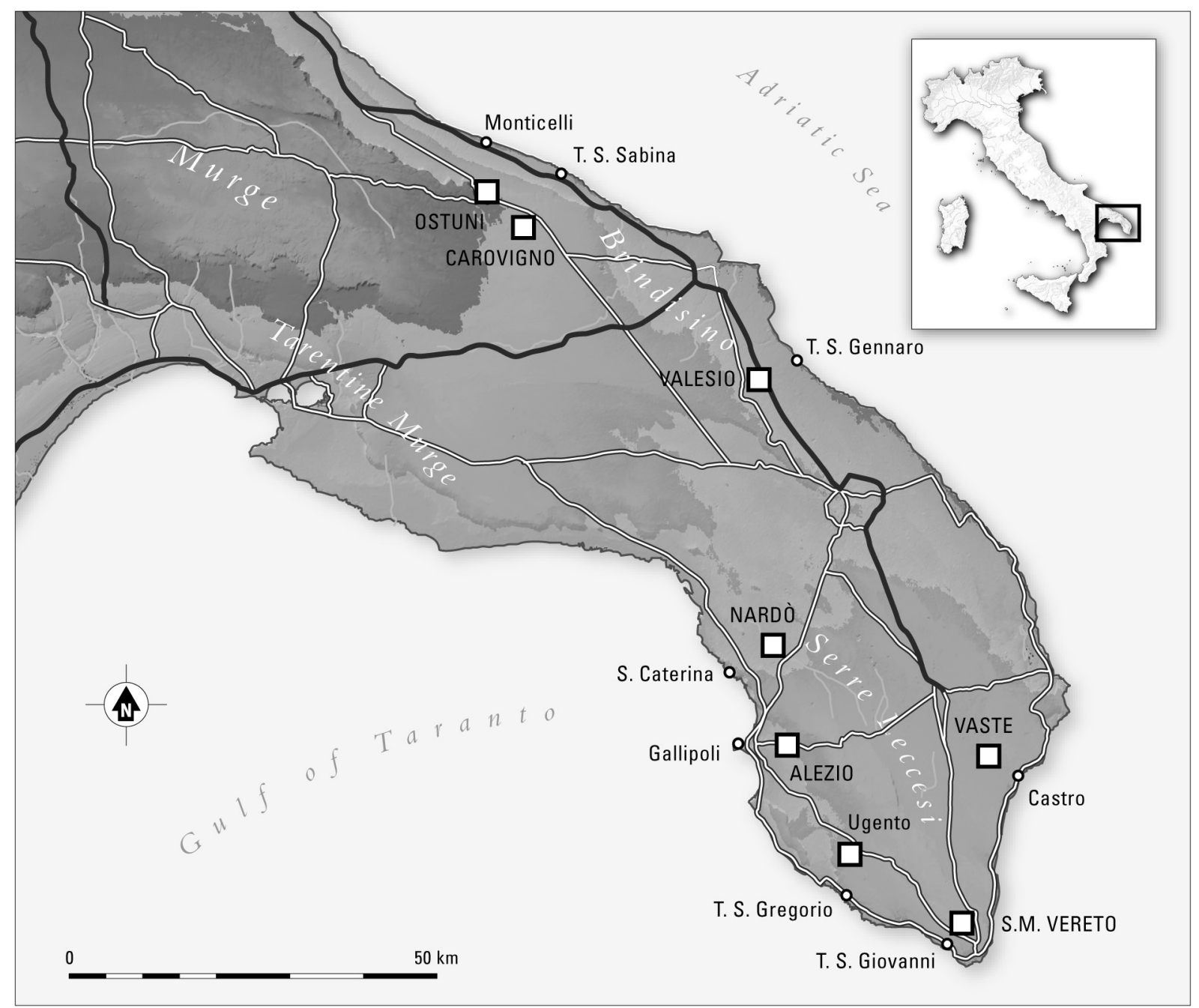

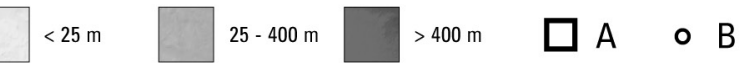

Fig. 6.49. South Apulia. System of "paired settlements" functioning between the 6th and the 3rd century BC; A major settlements; B coastal settlements.

personal radiance and their tribal allegiance. Here they elected their supreme official (meddix?) who was both their war leader and the symbol of tribal coherence.

In northern Apulia the tribal entities currently indicated as the Daunians are likely to have displayed a less complex socio-political structure. They lacked fortified towns and large tribal sanctuaries and lived in highly dispersed settlements. This notwithstanding, this area also tended towards more hierarchical political structures. Whilst there was a series of settlements of more or less equal status around the middle of the 4th century BC, Canosa was decidedly the most dominant settlement of the district in the basin of the lower Ofanto river by the early 3rd century. The settlement of Arpi began to play a similar central role in the more northerly Tavoliere district at approximately the same time. In these districts powerful and wealthy elites controlled the various local clans. Judging by the character of the architectural remains and the burial gifts, the social differences here may have been larger than in other parts of southeast Italy. 
In addition to the socio-political innovations that resulted in the clustering of formerly independent polities, there were enormous changes in the landscape and the economy. These were answers to the demographic stress, shifting identities and the 'Mediterranization' of the ancient economies. They were most drastic in the territories of the Italic groups. Many indigenous settlements were fortified with stone walls and became conspicuous marks in the landscape that persist to the present day. Though the use of space within their walls continued to reflect a tribal organization, the construction of many new houses and even entirely new habitation quarters resulted in the genesis of a more or less urbanized landscape. Large scale reclamations of natural environments (especially in the district controlled by non-Greek groups) resulted in large agricultural surpluses and a substantial decrease of natural habitats. The same action caused the birth of inhabited countrysides in every district of southeast Italy. Since most of these innovations require the participation of a considerable part of the local community, close cooperation between the various local clans was crucial. The clustering of tribes into confederations on the regional level, therefore, was paralleled by the clustering of clans on the local level, whilst the formation of a tribal aristocracy was echoed on the local level by the formation of a local aristocracy.

Stock raising (pigs, goats, sheep) also intensified between the middle of the 4th and the middle of the 3rd century BC. This resulted in more surpluses and further erosion of natural environments. A part of the surpluses generated in these ways was shipped over considerable distances. The innovations in both agriculture and stock raising made southeast Italy into an increasingly important player in the rapidly intensifying exchange networks of early Hellenistic times. Taras was the dominant economic centre of the whole region and an important starting point for transmarine enterprises. A thorough and systematic study of southeast Italy's trade of the late 4th and 3rd centuries has not yet been made. It might well reveal a surprising frequency of contacts and a great intensity of trade and exchange, especially with the eastern Mediterranean. Taras's habour must have been buzzing with activity in the period under discussion, both before and after the Roman conquest of $272 \mathrm{BC}$.

These new or more intense activities brought unprecedented prosperity all over southeast Italy. We have seen that elites manifested themselves markedly in both the Greek states and the non-Greek polities from the 6th century onward. In the flourishing 4th century $\mathrm{BC}$ the material culture that characterized people of high status, made a qualitative leap. Especially golden ornaments and bronze vessels seem to have been among the paraphernalia of elite status. They testify to competition and emulation by means of ostentatious display between elite groups with both native and Greek roots. It is uncertain how these groups with different cultural backgrounds communicated and organized their interrelations and whether, for instance, Greek and non-Greek elites intermarried.

In addition to the wealthy and powerful, we encounter a large group of relatively prosperous persons in the architectural remains and the burial sites of Greek and non-Greek settlements. In the poleis these people were present since the 6th century BC. Here they may have been craftsmen, moderately prosperous farmers and persons involved in small scale retail and trading activities. These people made up the major part of the citizen body of most Greek states. The presence of a large group of moderately prosperous persons in non-Greek settlements, however, is entirely new. From the late 4th century onward a substantial group of inhabitants of most non-Greek settlements of southeast Italy lived in a house with two or three rooms, drank wine from fine wares of Greek type, prepared food in a Grecian way by simmering and baking the ingredients in stew pots and casseroles and had access to elaborately decorated figured pots (for burials) that had been the prerogative of the native elites in earlier periods of southeast Italy's history. Excavations and field surveys suggest that this large group consisted predominantly of tribal farmers whose farmsteads could be situated both within the new walls of their town and in the rural zone that surrounded the settlement. The still limited quantities of craftsmen equally belonged to this large, moderately prosperous group of the non-Greek settlements.

In this general atmosphere of well-being and prosperity craft flourished, because larger groups within the local societies of southeast Italy had access to a greater variety of goods. In each larger set- 
tlement carpenters built new houses and repaired older specimens, potters produced household pottery such as storage jars, cooking pots and table wares in very considerable quantities, smiths hammered tools and farming implements, whilst other types of craftsmen elude us because the products they made do not preserve well in the soils of southeast Italy. Whilst the craftsmen were mostly full time specialists in the poleis, those living in the tribal settlements were sometimes part-timers functioning within the framework of the local clan. Many women in the settlements spent part of their time spinning wool and weaving cloths, and not exclusively for their own use.

The sanctuaries had their share in the newly won opulence. Votive offerings consisting of corn, beans, meat and artifacts were plentiful. The Greek urban sanctuaries often had monumental buildings since the 6 th or 5 th centuries. The most important sacred places of the native world were now monumentalized (e.g. Rossano di Vaglio and Oria), but continued to differ from the larger Greek sanctuaries. The non-Greek groups did not adopt the Greek temple but constructed sacred buildings that answered to the requirements of native cults which focused on water (especially in Basilicata) and caves (mostly in central and southern Apulia).

One of the most striking aspects of the period between 350 and $250 \mathrm{BC}$ is the decreasing differences between the originally indigenous groups and the Greek polities of southeast Italy. Both Greeks and non-Greeks were politically organized in confederacies and had forms of supreme leadership (the leading politician - usually the strategos - of Taras as leader of the Italiote League and the paramount chiefs of the tribal confederacies). Both the Greeks and non-Greeks lived in more or less urban settlements surrounded by fortifications. These towns were embedded in an intensely cultivated countryside with farmsteads, hamlets, rural sanctuaries and rural necropoleis. Both Greek and indigenous polities had wealthy elites that displayed their status in comparable ways, and a substantial moderately prosperous group that consisted predominantly of farmers and craftsmen. Moreover, the economies of Greek states and indigenous polities display close similarities and were clearly compatible. Greeks and natives lived in the same types of houses, cooked in comparable ways and used the same kind of artifacts for the same purposes. It was, however, especially in the social and religious spheres that the differences were pronounced. The indigenous polities had a social system in which kinship ties continued to be crucial, whilst class and status were important social cohesives in the Greek states. In religion they only shared the custom of depositing votive offerings, whilst their sacred places with their architectural outfit and the rites performed in these contexts differed enormously.

The preceding passage highlights the fact that various cultural groups with vastly different cultural backgrounds began to blend into a cultural koinè. Between the middle of the 4th and the middle of the 3rd century BC a 'southeast Italy culture' came into being that was shared by people with vastly different ethnic affiliations, speaking vastly different languages and having vastly different cultural backgrounds. Since the material culture seems so patently Greek, the process has been (wrongly) described as 'Hellenization'. But this convergence did not only regard material culture, economy or politics. It also regarded attitudes, behaviour and even loyalties. Much has been made, for instance, of the 'Lucanization' of the town of Paistom (Roman Paestum), formerly Greek Posidonia. The subjects painted on the 4th-century tomb slabs of Paestum were sometimes believed to be indicative of a Lucanian takeover of that polis. ${ }^{183}$ However, the people buried in those painted graves considered themselves neither as Greeks nor as Lucanians. They were Paestans who functioned within a south-Italic cultural framework and held south-Italic views. These paintings, therefore, are indicative of a mental change that was the result of the interaction between Lucanian, Greek and other cultural features. Very similar

183 Pontrandolfo Greco / Rouveret 1992. 
mental changes occurred everywhere in southeast Italy on a large scale. This same spirit of convergence can even be observed in politics during the Pyrrhic war (281-272) when the Messapian groups, the Lucanian confederacy and the Italiote League sided against the Romans and lost. The genesis of a regional koinè in southeast Italy was a long-term process in which periods of great ferment alternated with decades of much slower change. The formation of a south-Italic cultural koinè started in the 7th century when the first stable Greek communities of southeast Italy came into being, and had progressed enormously at the time of the Pyrrhic war. The hybrid South-Italy culture of that time blended with a process of Romanization which started when the first Roman communities were established in southeast Italy. Both processes resulted in an rich and intricate cultural patchwork in southeast Italy displaying elements from many different sources, both inside and outside southeast Italy. 
